\title{
Land-use dynamics, economic development, and institutional change in rural communities - Evidence from the Indonesian oil palm sector
}

\author{
Dissertation \\ zur Erlangung des Doktorgrades \\ im Promotionsstudiengang Internationales PhD. Programm für Agrarwissenschaften \\ (IPAG), \\ der Fakultät für Agrarwissenschaften, \\ der Georg-August-Universität Göttingen
}

vorgelegt von

Marcel Gatto

geboren in Mettingen

Göttingen, Januar 2015 
1. Name of supervisor: Prof. Dr. Matin Qaim

2. Name of co-supervisor: Jun.-Prof. Dr. Meike Wollni

Date of Dissertation: 12.02.2015 


\section{Summary}

This dissertation is an empirical investigation of the implications of the Indonesian oil palm sector for rural village communities located in Jambi province, on the island of Sumatra. It consists of three contributions to the scientific literature on land-use dynamics, economic development, and institutional change.

In Chapter 1, I introduce the reader to the general topic of this research and give a brief overview of the development of the Indonesian oil palm sector, embedded in a historical context. I further outline how this study contributes to the existing literature and present the overall research objectives that will be addressed in the subsequent individual chapters. Specifically, this study examines land-use dynamics and attempts to explain land-use by various determinants at the village level (Chapter 2); it analyzes factors predicting the inclusion of village communities into the oil palm sector and evaluates the effects of market integration on economic development at the village level; finally, it explores the effects of market integration on village institutions (Chapter 4).

In Chapter 2, I examine land-use dynamics at the village level of three major land-use systems: oil palm, rubber, and forest. The dynamics are analyzed by looking at land-use over time. In particular, I am interested in explaining village-level land-use in 2002 and 2012 by several lagged land-use systems as well as socioeconomic and policy variables. Econometrically, a seemingly unrelated regression model is applied which accommodates a simultaneous estimation of various equations and accounts for the likely correlation of the land-use equations. I find that in spite of significant oil palm expansion, rubber remains the dominant crop. The data also suggest that oil palm has not been a major driver of deforestation but indirect effects are possible since oil palm expands in areas with ongoing logging activities. Regarding socioeconomic and policy factors, especially a relocation program seemed to be instrumental to the oil palm development. 
In Chapter 3, I investigate the factors that determine the inclusion of villages into the oil palm sector through contract farming schemes and evaluate the impact of this form of market integration on economic development. Since the adoption of contract farming arrangements is conditional on an investor who visits a village to propose a contract, I investigate contract adoption as a two-step model. In particular, I employ a bivariate model with selection. This allows me to estimate the impact of various factors on the probability of contract adoption by accounting for the factors that predict the probability of investor visit. At the same time, I can account for a possible selection bias. To identify the model, a topographic measure is used as an instrument. I find evidence that, conditional on being visited by an investor, no access to electricity at the village level was the only significant factor predicting the adoption of contract farming schemes. Overall, it appears that, at the village level, contract farming schemes have not been entirely equally accessible; however, I do not find evidence that the rural poor were excluded either.

Furthermore, to examine the effects of market integration on economic development at the village level I use village wealth that is based on shares of households owning various assets as a proxy. A recall dataset is used to analyze wealth effects over time, in particular between 2002 and 2012. The estimation exercise reveals that villages in which a contract was signed have a higher wealth index compared with villages in which no contract was adopted. Moreover, larger groups of farmers under contract are associated with higher levels of village wealth. I also find a time effect: the wealth index is higher in villages that signed a contract earlier than those which did so more recently.

In Chapter 4, I explore the effects of increased formalized market integration on village institutions. Specifically, I want to understand how contract farming schemes, that introduce institutional changes towards more formalized and anonymous business relationships, affect generalized trust preferences at the village level. In using both survey data and behavioral data elicited through an experiment, I show that villages in which a contract was signed exhibit larger aggregated trust preferences, compared with 
villages where no contract was signed. This is due likely to a change in village institutions induced by the emergence of formalized relationships between contract farmers and anonymous business actors. Further analysis at the individual level reveals that market integration of villages has a positive effect on generalized trust preferences for all village inhabitants, contracted or not. Possibly, apart from contract participation increased investments in transportation and market infrastructure also increased the integration of non-contract villagers into more formalized and anonymous markets.

In Chapter 5, I conclude by summarizing the overall study and by stressing the key findings. I further present some derived policy recommendations and state the limitations of this study along with avenues for future research. 


\section{Acknowledgments}

This dissertation is the result of three years of 'doing a $\mathrm{PhD}$ '. For many people not familiar with academia this predominantly entails reading infinite amounts of books and articles as well as spending endless hours on the computer 'doing statistics' and 'writing papers'. The process of 'doing a PhD' can be lonely sometimes, however, it is definitely not as lonely a process as it is oftentimes perceived. For me in particular, I frequently interacted with many people from various disciplines and cultural backgrounds during my PhD. I am very grateful for all the people I have met, many of whom I became friends with, and the incredible learning experience I have had whilst 'doing a PhD'.

But before I start with the extensive list of people that have made this $\mathrm{PhD}$ less of a lonely process, I would like to mention the people that have made this process possible in the first place, and have guided me on my path to attain my doctorate. In particular I want to acknowledge, first and foremost, my supervisor Matin Qaim for funding my $\mathrm{PhD}$ position. I am very thankful for his guidance, support and ability to put things into perspective. I also want to express my gratitude to my co-supervisor Meike Wollni. I am thankful for her help and support during the past three years, and especially for the oftentimes long-lasting spontaneous meetings we had discussing some preliminary findings. I would like to thank Oliver Mußhoff as the third member of the board of examiners. In addition, for financial support the German Research Foundation (DFG) is gratefully acknowledged.

Furthermore, I would like to thank all of my colleagues from the Georg-AugustUniversity of Göttingen. I am especially grateful to our brilliant postdocs Vijesh Krishna and Stefan Schwarze for their helpful comments and for always having an 'open door' for me. Of course, I am very glad that I shared an office with Wilhelm Klümper for almost the entire period of my studies. Although he did work on a different topic, we had good conversations and he was oftentimes very helpful in method-related aspects. But, I 
am also grateful to a couple of people for their constructive discussions and valuable comments. These are in particular, Michael Euler, Cristina Romero, Stefanie Steinebach, Prakashan Veettil, Brigitta Hauser-Schäublin, and Marcela Ibanez.

This dissertation is a result of a collaborative research center, named CRC 990. Without the help and support of many colleagues and people who are affiliated to the CRC 990 this dissertation would not have been possible. In particular I would like to thank my Indonesian colleagues Ibu Rosyani of the University of Jambi and Pak Bambang Juanda of IPB Bogor. But also for administrative support in Göttingen and the practical support 'in the field' I would like to express my gratitude to Barbara Wick, Wolfram Lorenz, Bambang Irawan, Mira, and Rizky; my student assistants from Jambi Anti, Andy, Ceki, Lisa, Rizka and Sayful; our driver Herman; and Sandra Tappendorf for her great support as a research assistant. In addition, I would like to thank all the people we interviewed in the field for their willingness to share their knowledge and personal information as well as for their patience.

Next to a working life my social life was important to me. I would like to thank a couple of people who made my stay in Göttingen an unforgettable experience. Especially I am thankful to Ibu Josie; the Americans: Kara, Lisa and Andrew; Krissy, Alex, Natascha, Thomas, Tom, Martin, Andi, Nico, Sebastian; and finally, C(h)ristina, Laura and Ayako for being my 'female support group'.

I would like to acknowledge Maarten van Gijn and Martin Engelhaupt, who were both friends and support to me during the first phases of my $\mathrm{PhD}$, but sadly passed away too early. I would have really liked to share this moment with them.

Natürlich darf 'Die Band' nicht vergessen werden. Es ist immer wieder schön zusammen Musik zu machen und Freunde zu treffen. Danke für den guten Ausgleich.

Natuurlijk wil ik ook mijn familie bedanken die er altijd voor mij is en mij steunt in alles wat ik tot nu gedaan heb. Bedankt papa \& mama, Ralf, Arnold, Yolanda. Ik weet dat 
jullie erg trots zijn, maar jullie moeten weten dat ik er ook erg trots op ben om zo'n familie te hebben! Bedankt voor alles!

Enfin, Maartje, jij bent diegene die altijd in mij gelooft, die mij telkens weer stimuleert kritisch te denken en het beste uit mij kan halen. Hier ben ik jou erg dankbaar voor! En naturrlijk wil ik jou ook bedanken voor jouw fysieke inspanningen in Indonesie, en voor het copyediten van mijn proefschrift.

Op naar het volgende hoofdstuk! 


\section{Table of contents}

Summary $\quad$ iii

Acknowledgments $\quad$ vi

Table of contents $\quad$ ix

List of tables $\quad x i$

List of figures $\quad$ xii

Abbreviations $\quad$ xiii

Chapter 1 Introduction 1

1.1 General background 1

1.2 The Indonesian frontier 5

1.3 Challenges and opportunities $\quad 8$

1.4 Problem statement and research objectives 9

$\begin{array}{lll}1.5 & \text { Dissertation outline } & 14\end{array}$

Chapter 2 Land-use Dynamics: The Role of Policies and Socioeconomic Factors 16

2.1 Introduction 16

2.2 Background 18

2.3 Materials and methods 21

2.4 Results 26

2.5 Discussion 37

$\begin{array}{lll}2.6 & \text { Conclusion } & 42\end{array}$

Chapter 3 Contract Farming and Economic Development 44

3.1 Introduction 44

3.2 Background 47

3.3 Materials and methods 51 
$\begin{array}{lll}3.4 & \text { Results and discussion } & 60\end{array}$

$\begin{array}{lll}3.5 & \text { Conclusion } & 72\end{array}$

Chapter 4 Market Integration and Institutional Change 75

$\begin{array}{lll}4.1 & \text { Introduction } & 75\end{array}$

$\begin{array}{lll}4.2 & \text { Study context } & 79\end{array}$

4.3 Materials and methods $\quad 80$

$\begin{array}{lll}4.4 & \text { Results } & 86\end{array}$

$\begin{array}{lll}4.5 & \text { Conclusion } & 95\end{array}$

$\begin{array}{lll}\text { Chapter } 5 \text { Conclusions } & 99\end{array}$

$\begin{array}{lll}5.1 & \text { Synopsis } & 99\end{array}$

$\begin{array}{lll}5.2 & \text { Policy recommendations } & 104\end{array}$

$\begin{array}{lll}5.3 & \text { Limitations and future research } & 105\end{array}$

$\begin{array}{ll}\text { References } & 108\end{array}$

Appendix A: Additional tables $\quad 121$

Appendix B: Questionnaires 126

Appendix C: Script for trust experiment 151 


\section{List of tables}

Table $1 \quad$ Village descriptive statistics

Table 2 Land-use equations (SUR model)

Table 3 Model results with interactions between migration dummies and land-use systems (SUR model)

Table 4 Model results with interactions between migration dummies and other socioeconomic variables (SUR model)

Table 5 Descriptive statistics I

Table $6 \quad$ Descriptive statistics II

Table 7

Probit estimation results for determinants of investor visit and contract adoption

Table 8 Panel estimation results for contract adoption, contract size and contract length

Table 9 Panel estimation results for contract adoption, contract size by adoption phase

Table $10 \quad$ Descriptive results of aggregated trust levels

Table 11 Descriptive results of individual trust levels for contract villages

Table 12 Summary statistics of experimental results and respondents

Table 13 Summary statistics and description of village-level variables

Table 14 Determinants of aggregated generalized trust

Table $15 \quad$ Estimation results for indirect trust effects 


\section{List of figures}

Figure $1 \quad$ Global palm oil fruit production between 1990-2012

Figure 2 Global area under oil palm cultivation between 1990-2012

Figure 3 Map of Jambi province with sample villages

Figure 4 Land-use change in Jambi province between 1990-2012

Figure $5 \quad$ Contracts rejected and accepted at village by year

61

Figure 6 Average share of contract households per contract village by 


\section{Abbreviations}

CRC Collaborative Research Center

FAO Food and Agriculture Organization of the United Nations

FFB Fresh fruit bunches

IDR Indonesian Rupiah

IV Instrumental variable

NES Nucleus estate schemes and smallholders

OLS Ordinary least squares

PODES Indonesian national village census

SUR Seemingly unrelated regression

USD United States Dollar

WI Wealth index

2SLS Two stage least squares 


\section{Chapter 1}

\section{Introduction}

\subsection{General background}

During the past decades large strides against poverty have been made, yet millions of rural people are still considered extremely poor and suffer from undernutrition. According to estimates provided by the Food and Agriculture Organization (FAO), in 2014, some 1 billion people still live in extreme poverty and more than 800 million people continue to go hungry. In addition, despite the fact that these problems exist across the world, there is a clear rural tendency. More than $70 \%$ of the people who are deemed poor live in rural areas in developing and transition countries and make a living in the agricultural sector as low-paid farm laborers or subsistence producers (FAO, 2014).

A widely adopted strategy to alleviate poverty has been through promoting economic development (Ravallion, 2001; Dollar and Kraay, 2002). Whereas at first, states largely controlled their agricultural sectors, in 1981, the World Bank released a report that argues in favor of economic adjustments towards privatization and market liberalization to accelerate economic development (World Bank, 1981). As a result, in many developing and transition countries, governments retreated from controlling agricultural production and marketing and cleared the way for private sector engagement (Swinnen and Maertens, 2007). Apart from the rationale to liberalize (agricultural) economies as a strategy to reduce poverty, several developments from the more recent past prompted governments to stimulate agricultural sectors and to continue their efforts to attract commercial agricultural investments. First, the increasing global demand for food, biofuels and natural resources that is largely driven by increasing global population and rising incomes is noteworthy. But also the period of high and volatile prices following the 2007-2008 commodity price boom and the global financial crisis reminded many 
countries of the need to be more independent of imports to reduce vulnerability to price shocks (World Bank, 2011).

Thus, various stimuli and global developments have induced immense agricultural investments worldwide. On the one hand, investments were made into improved technology (e.g. machinery, improved seed varieties) to intensify existing modes of agricultural production. On the other hand, governments invested considerably in the expansion of their agricultural activities. As an inevitable result, rural landscapes have been undergoing substantial transformations. Especially, cultivation of perennial crops, such as oil palm, sugarcane, but also plantation forests, has gained considerable importance (World Bank, 2011). According to official figures, globally, between 1990 and 2012, perennial cropland drastically increased by one-third, from 119 million to 163 million ha, respectively (FAOSTAT, 2014). At the same time, rural landscapes have been experiencing substantial reduction in forest area. In this regard, between 2000 and 2012, the world lost 230 million ha of its total forest cover. Especially, this trend is well pronounced in tropical regions. For example in Brazil, the historical leader of clearing forests, total forest cover loss amounted to some 35 million ha between 2000 and 2012 . In comparison, total forest cover loss merely amounted to some 16 million ha in Indonesia. Nevertheless, the Southeast Asian country has recently become the country with the world's highest deforestation rate (Hansen et al., 2013). Also in terms of clearing tropical primary forests Indonesia is leading, having an annual primary forest loss that is almost double that of Brazil by 2012 (0.84 million ha and 0.46 million ha, respectively; Margono et al., 2014).

Whereas tropical rural landscapes have endured considerable forest cover losses, agricultural investments into these regions are increasing. In particular, the rapid expansion of the oil palm sector stands out. Palm oil, a vegetable oil extracted from the oil palm tree, today, is one of the most demanded commodities worldwide. Global palm oil production more than quadrupled from some 61 million to almost 260 million tons of 
palm oil from 1990-2012 (Figure 1). More specifically, with a total production of 220 million tons in 2012, Asia is by far the largest producer of palm oil fruits worldwide.

Figure 1. Global palm oil fruit production between 1990-2012

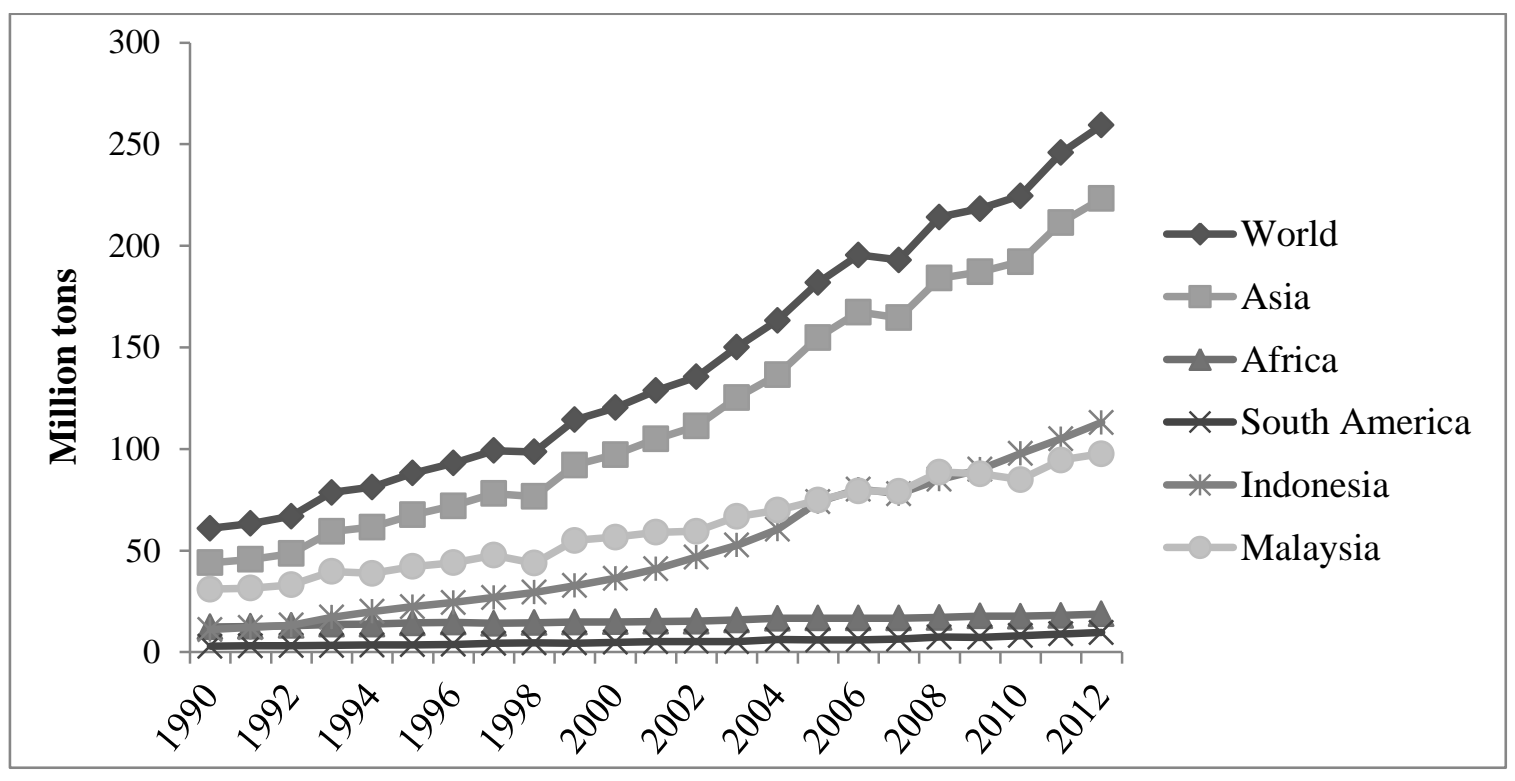

Source: FAOSTAT (2014)

In contrast to Asia, both Africa's and South America's palm oil fruit production of 19 million and 10 million tons in 2012, respectively, appears meager. Taking a look at global land-use figures reveals how the oil palm area has been expanding: from 19902012, the global oil palm area tripled to almost 18 million ha (Figure 2). Already since the mid-1990s most of the global oil palm area is located in Asia where in 2012 some 12 million ha were under oil palm cultivation. Compared with Africa (4.7 million ha) and South America (0.6 million ha), Asia can be considered a hotspot of global oil palm cultivation. However, whereas the application of lower-yielding varieties and higher production costs in Africa may explain the land-use disparity with Asia (Carrasco et al., 2014), global demand for palm oil is voracious (Corley, 2009). Sooner or later the suitable land for oil palm production in Asia will be exploited and, consequently, agroindustrial estates have already started to invest in Africa's tropical regions (Wich et al., 2014). 
Figure 2. Global area under oil palm cultivation between 1990-2012

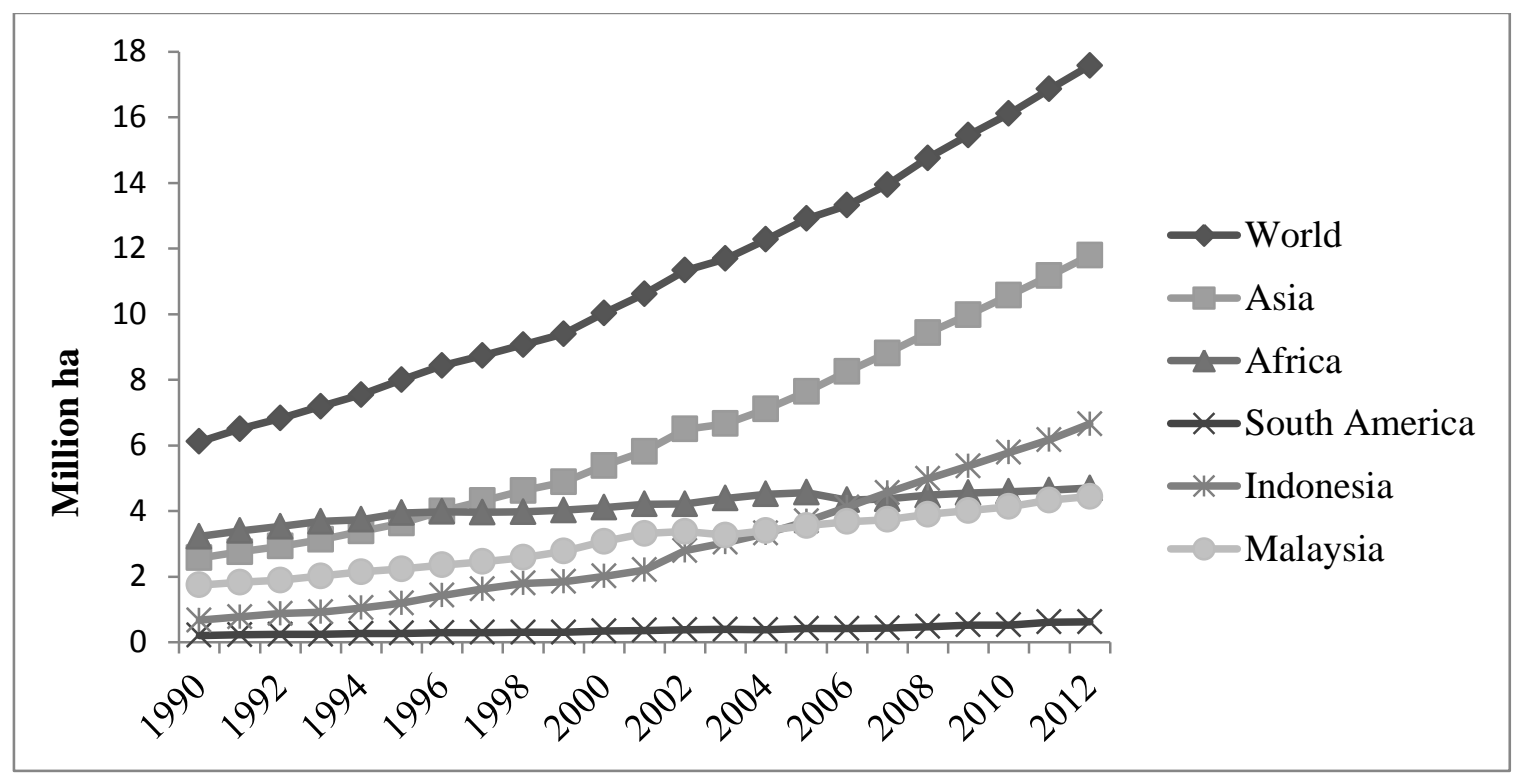

Source: FAOSTAT (2014)

The boom is due largely to several factors. First, palm oil is versatile: it may be used for edible purposes but also constitutes an important ingredient in cosmetic products and biofuel (Carter et al., 2007). Second, compared with other vegetable oils like rapeseed and soya, palm oil is cultivated more productively and production costs are lower (Carter et al., 2007; World Bank, 2011). The latter is partly a result of how oil palm is usually cultivated; large-scale monoculture plantations that fully integrate production and marketing of the crop allow the achievement of large economies of scale. Frequently, governments stimulated the involvement of smallholder farmers under contract farming arrangements (Swinnen and Maertens, 2007). This offered a viable strategy to alleviate poverty by promoting rural economic development. At the same time, the vertical integration (i.e. contract farming) introduced considerable institutional changes towards more formalized and anonymous business relationships.

In sum, various drivers, such as a rationale to promote economic development, resilience to shocks, but also population growth, rising incomes and thus increasing global demand 
for natural commodities, induced public and private agricultural investments. At the same time, tropical landscapes are increasingly under pressure experiencing substantial reduction of forest and a vast expansion of agricultural land. In this regard, the oil palm expansion in Indonesia, which lies at the center of this dissertation, is definitely one of the most rapid as well as contested recent developments. In the following section, I will focus on the oil palm sector in Indonesia and will stress various aspects of it, embedded in a brief historical account that will be useful to keep in mind while reading the remainder of this thesis.

\subsection{The Indonesian frontier}

In 2008, Indonesia overtook Malaysia and became the world's number one producer of palm oil, reaching a total production of 113 million tons in 2012 (Figure 1). Besides that, also in terms of total land area under oil palm cultivation Indonesia is leading. From 1990-2012, the oil palm area increased tenfold to reach some 6 million ha (Figure 2). This development caused tremendous transformations of tropical landscapes. In addition, many oil palm leases granted to private companies currently remain undeveloped (Carlson et al., 2013) which makes more transformations towards oil palm monoculture likely in the near future. In economic terms, the Indonesian oil palm sector has created an estimated 1.7 million to 3 million jobs (World Bank, 2011), and it has been reported to substantially contribute to increasing rural incomes (Barlow et al., 2003; Susila, 2004; Zen et al., 2005) and to considerable national benefits generated from export revenues (Sheil et al., 2009).

Jointly, these land-use and economic outcomes are the result of governmental efforts to promote an emerging sector. Whereas production and marketing of palm oil was directly controlled by the state at first during the early 1980s, in subsequent years the government increasingly incentivized the engagement of selected private agro-companies by 
providing access to land and credits at concessionary interest rates (Larson, 1996; McCarthy, 2010).

During these years the development of the oil palm sector went hand in hand with another policy objective. Through the relocation of people from densely populated areas (e.g. Java) to regions of land abundance (i.e. Sumatra, Kalimantan) the government intended to stimulate the development of Indonesia's outer islands (Budidarsono et al., 2013). The so-called transmigration schemes provided a readily disciplined labor force to meet the increasing demand for plantation and factory workers (McCarthy, 2010). On the other hand, by involving these so-called transmigrants in palm oil production the government could work towards achieving its population redistribution policy.

In 1998, after the fall of Suharto's New Order regime the new government further stimulated the oil palm sector, but with a different approach: the government retreated for the most part and approved reforms to liberalize markets that promoted a substantial influx of private agro-companies (Larson, 1996; McCarthy, 2010). Official figures confirm this trend, from 2000-2012 the number of operational large-scale oil palm plantations more than doubled from some 700 to about 1500 estates (Ministry of Agriculture, 2014).

In addition to opening agricultural sectors for private companies, the emerging oil palm sector was instrumental for the promotion of rural socioeconomic development through involving smallholder farmers (Zen et al., 2005). In doing so, the government relied on past experiences from Malaysia during the 1970s and introduced a joint venture scheme between private companies and cohorts of smallholder farmers (Feintrenie et al., 2010a). This scheme that is often referred to as Nucleus Estates Scheme and Smallholders (NES) usually entails a plantation that is equipped with a processing factory at the center and surrounding estate plantations. In the outer circle smallholdings are located for the farmers who participate in contract farming schemes. These outgrower schemes are in proximity to the center to guarantee that the fresh fruit bunches (FFB) can be processed 
before they perish; usually this starts 48 hours after these are harvested (McCarthy, 2010).

Since the advent of oil palm, different forms of the NES schemes have evolved in Indonesia. At first, during the 1980s and early 1990s, private companies were required to develop NES schemes by incorporating smallholder farmers in outgrower schemes in exchange for access to land and capital. Later, a process of decentralization shifted political and budgetary responsibilities down to the district and village level. This allowed companies to engage in community-company 'partnerships' and more directly negotiate with groups of farmers or farmer cooperatives about available communal land to be transformed into oil palm plantations (Feintrenie et al., 2010a; McCarthy et al., 2012). Generally, the institutional foundation of the relationship between private companies and smallholder farmers has constituted formal contracts. On the one hand, contract farming provided a viable opportunity for farmers to overcome the barriers associated with oil palm cultivation (e.g. high initial investment costs, knowledge intensive production process, and limited access to input and output markets). On the other hand, contracts guaranteed a continuous supply of FFB allowing processing mills to operate at optimal levels. Whereas initially smallholder farmers were largely supported and dependent on the provision of crucial services, since the late 1990s a growing number of independent smallholder farmers have emerged. In figures, from 2000-2012, Indonesian smallholder farmers considerably increased their share of land under oil palm cultivation from 0.24 to 0.38 . In contrast, for the same period the share of oil palm land cultivated by private plantations decreased from 0.61 to 0.55 (Ministry of Agriculture, $2014)^{1}$.

\footnotetext{
${ }^{1}$ Unfortunately, these figures do not distinguish between dependent and independent smallholder farmers.
} 


\subsection{Challenges and opportunities}

The tremendous agricultural investments that were made into the Indonesian oil palm sector pose both challenges and opportunities for the environment and smallholder farmers alike. As mentioned, the development of the oil palm sector through opening markets and allowing private companies to enter the industry resulted in substantial economic benefits for Indonesia as a whole. But also, at the local level the continuous integration of smallholder farmers in large-scale plantations improved rural livelihoods (Barlow et al., 2003; Susila, 2004; Zen et al., 2005, Sheil et al., 2009).

However, major challenges evolved at the same time. For example, through agricultural investments private companies have been extensively involved in commercial acquisitions of 'non-private' lands. Due to unclear land rights many incidents have been reported on the exploitation and dispossession of rural communities that lead to (yet unresolved) land conflicts (Wakker, 2005; Colchester et al., 2006; Marti, 2008; Borras and Franco, 2010). Furthermore, in the wake of decentralization, district officials who have been largely involved in issuing planting permits sometimes abuse their position of authority to benefit personally (Marti, 2008). Moreover, the contractual relationship between smallholder farmers and private companies has also frequently been afflicted with conflict. Especially, in 'decentralized-localized community-based' negotiations, contractual arrangements have not always been transparent and lacking free, prior and informed consent (Rist et al., 2010, McCarthy et al., 2012).

The involvement of private companies and smallholder farmers in the Indonesian oil palm sector has induced tremendous changes in rural landscapes towards oil palm monoculture. As mentioned, at the same time the forest cover is decreasing at increasing rates (Hansen et al., 2013). Often the expansion of oil palm is held responsible for the observed high deforestation rates in the tropics (Curran et al., 2004; Carlson et al., 2012; Margono et al., 2012; Margono et al., 2014) and other negative environmental/ecological consequences, such as biodiversity loss (Fitzherbert et al., 2008; Koh and Wilcove, 2008; Wilcove and Koh, 2010; Wilcove et al., 2013; Barnes et al., 2014), loss of carbon stocks 
and peat degradation (Koh et al., 2011; Carlson et al., 2013), forest fires and thus increased greenhouse gas emissions (Dennis et al., 2005), and water pollution and soil erosion (Obidzinski, et al., 2013).

\subsection{Problem statement and research objectives}

In the previous section, I stressed some general opportunities and challenges associated with the emerging oil palm sector in Indonesia. In what follows, I will more specifically address current research gaps and indicate the contribution of this dissertation.

Large-scale agricultural investments have caused tremendous transformations of tropical landscapes where land-use changes towards monoculture oil palm have often been associated with detrimental effects on tropical forests. In the general deforestation literature, the primary goal has usually been to quantify forest cover losses, deforestation rates and infer the environmental consequences associated with the observed trends (see for example DeFries et al., 2002; Hansen et al., 2010; Hansen et al., 2013). Conducting analyses at large scales (i.e. national but also global) require an appropriate data collection method. Therefore, global analyses of land-use changes are usually based on remotely sensed data recorded for various periods of time. In doing so, it has been of marginal importance to actually identify the drivers of land-use change. In spite of a growing strand of literature that combines remote sensing data with survey data to identify drivers of land-use change (Muller and Zeller, 2002; Caviglia-Harris and Harris, 2008, De Souza Soler and Verburg, 2010), the literature remains scant.

In particular within the oil palm context, the related literature has often presented landuse maps that accurately outline current and past land-use trajectories (Curran et al., 2004; Carlson et al., 2012; Carlson et al., 2013). But little emphasis has been placed on the drivers that determine these dynamics, although these can be manifold (Lambin et al., 2003). For example, land-use change may be related to (past) socioeconomic conditions in the area but also government policies may play a decisive role. Focusing on the drivers 
of land-use change could help adjust policies that aim to avoid undesirable outcomes. In addition, the literature either adopts a general perspective on the oil palm expansion or specifically focuses on agricultural industries (Carlson et al., 2012). In different words, the impact local communities may have on inducing land-use changes and transforming tropical landscapes has largely been neglected. The urgency to address this gap in literature is rising considering the increasing importance of smallholder farmers within the Indonesian oil palm sector.

The emergence of an oil palm sector in Indonesia has, as mentioned, affected millions of rural livelihoods. However, despite the fact that private oil palm companies and the involvement of smallholder farmers under contract farming schemes have been shaping economic outcomes already for more than the past three decades, the empirical evidence remains scarce and mixed. For example, authors have pointed out that, in addition to the mentioned negative social implication (i.e. land and contractual conflicts), contract farming arrangements have not equally been accessible to all farmers (McCarthy, 2010). Another study concludes that richer contracted smallholders tend to benefit considerably more compared to their poorer fellow smallholders (Cahyadi and Waibel, 2013). On the other hand, oil palm cultivation has contributed to increased incomes and higher returns to land and labor (Feintrenie et al., 2010; Rist et al., 2010; Cahyadi and Waibel, 2013). Overall, this strand of literature examines socioeconomic effects for rural farming households. Considering, however, that the emergence of the oil palm sector induced investments into transportation and market infrastructure (Larson, 1996), broader development implications for local communities have largely been neglected. In addition, research has mainly relied on case study and descriptive analyses, restricting broader inferences and thus also limiting the formulation of sound policies.

Moreover, focusing on local communities rather than households allows the adoption of a broader perspective on the inclusion into the oil palm sector. To date, studies have mainly focused on households' decisions to adopt oil palm contracts within village communities (see for example McCarthy, 2010; Cahyadi and Waibel, 2013). In 
particular, in the oil palm sector private investors have targeted entire village communities. In addition, the decision to adopt or reject a contract offer proposed by an investor is usually a group outcome preceding negotiations that took place at the village or farmer cooperative level (McCarthy and Cramb, 2009). To the best of our knowledge, an empirical investigation on the factors that determine contract adoption across villages is missing in the literature.

Apart from visible effects on land-use and economic development, the emergence of the Indonesian oil palm sector increasingly integrated rural villages into formalized markets and thus also affected more intangible aspects of village life; specifically, village institutions. In detail, village communities were increasingly integrated into formalized markets through contract farming arrangements (Swinnen and Maertens, 2007). A small but growing strand of literature examines the relationship between such institutional changes (i.e. formalizing institutions) and informal institutions, such as trust. The empirical evidence, however, remains scarce and also mixed. Whereas the majority of the findings suggest that formalized institutions, such as formal market integration, has a positive effect on trust levels (Berggren and Jordahl, 2006; Fischer, 2008, Henrich et al., 2010; Meijerink et al., 2014), other scholars report lowered trust levels (Siziba and Bulte, 2012). Most of the mentioned studies base their results on cross-country analysis and, in addition, measure trust preferences with survey questions. However, it has been argued that survey questions, as used in the World Value Survey, are often ill-suited to actually measure trust (Glaeser et al., 2000). Thus, more research is required to contribute to the existing empirical literature investigating the link between market integration and trust by applying measures of trust that go beyond simple survey questions.

Taken together, in this dissertation I study the implications of a specific emerging agricultural sector within three different, yet related, domains of a village community. In more detail, I empirically investigate the effects of the Indonesian oil palm sector on land-use dynamics, economic development, and institutional change. Rural areas in the 
province of Jambi were chosen as the study location because Jambi represents a tropical frontier of transformations towards oil palm plantations (Faust et al., 2013). ${ }^{2}$

In addition, I want to stress that the village is the unit of analysis in the overall study. In contrast to more disaggregated and conventional analyses, say, at the individual level, the village level allows for the examination of broader implications on land-use dynamics, economic development, and institutional change. Conducting the analysis at the village level allows me to examine land-use dynamics by taking wider spatial areas into consideration. In addition, I can evaluate broader socioeconomic and institutional implications for entire village communities. In particular for the oil palm sector in our study region a village-level analysis provides a natural perspective: rather than individuals, oil palm investors targeted entire villages for the inclusion into the oil palm sector. Furthermore, in case a contract was signed in a village, the inclusion into the oil palm sector induced the transformation of many village aspects (i.e. village organization, infrastructure, institutions) likely affecting all village inhabitants, contracted or not. Finally, with the adoption of a village-level perspective I intend to provide an unconventional look that could support policy-makers in the formulation of comprehensive policies.

I formulate the following research objectives:

1. Examining land-use dynamics and explaining land-use by various determinants (i.e. socioeconomic and policy).

2. Analyzing factors predicting the inclusion into the oil palm sector and evaluating the effects of market integration on economic development.

3. Exploring the effects of market integration on village institutions (i.e. generalized trust).

2 This study is part of a collaborative research center (CRC) which focuses on ecological and socioeconomic functions of tropical lowland rainforest transformation systems. Thus, not only oil palm as a major transformation system lies at the core of the overall research center but also rubber plantations and rubber agroforestry. Please refer to Faust et al. (2013) for a detailed description of the study area and further information on the objectives of the CRC. 
To address the research objectives, I make use of both survey and behavioral data that were collected through a structured questionnaire and an economic experiment, respectively. For details on the village questionnaire please refer to B1 in the Appendix. The behavioral data were elicited through an experimental game. A total of 902 respondents, who were selected on a random basis prior to participation, participated in the experiment. All respondents also participated in a short individual survey after the experiment (B2 in the Appendix).

Figure 3. Map of Jambi province with sample villages

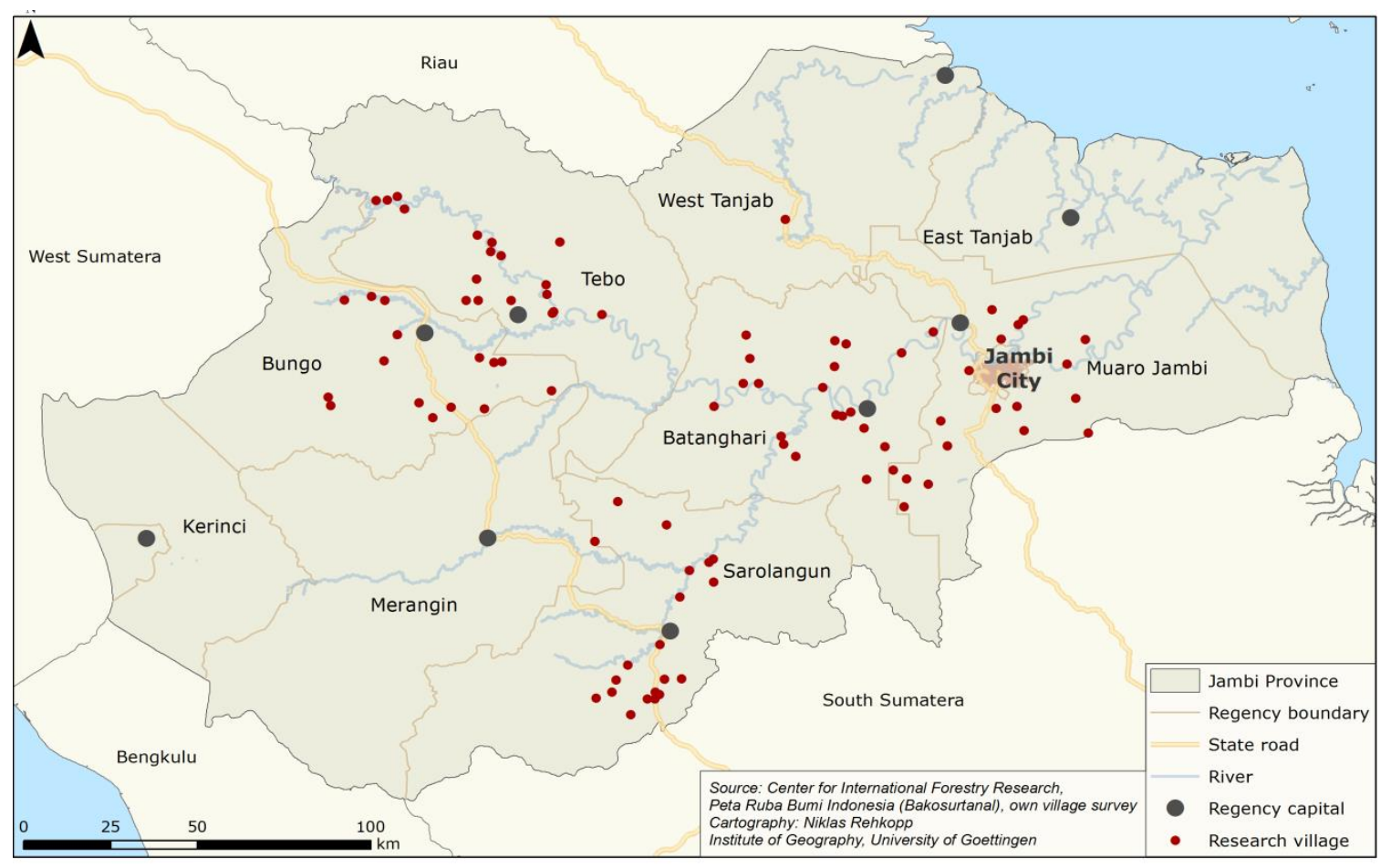

The data are collected in a total of 98 villages in Jambi province (Figure 3). Regarding the general sampling strategy, I purposively selected five districts in the lowlands of Jambi province. These districts, namely Muaro Jambi, Batang Hari, Sarolangun, Tebo, and Bungo, have largely been affected by agricultural investment and, thus, are subject to major land-use changes. On a random basis I further selected 25 sub-districts, five per district. For all 25 sub-districts I compiled complete lists of villages using data from the 
Indonesian national village census (PODES). From these lists, I randomly sampled four villages per sub-district, resulting in a total of 100 villages. However, due to logistical problems, two of these villages could not be reached, leaving us with a total sample of 98 villages for this study. ${ }^{3}$ The data collection took place between September and December 2012.

\subsection{Dissertation outline}

This study is organized as follows. The above formulated research objectives are individually addressed in the subsequent chapters. Thus, Chapter 2, which addresses research objective one, examines land-use dynamics and analyzes village-level factors that are associated with observed land-use. Specifically, I analyze land-use dynamics of three major land-use systems: oil palm, rubber, and forest. The dynamics are analyzed by looking at land-use over time. In particular, I explain village-level land-use in 2002 and 2012 by several lagged land-use systems as well as socioeconomic and policy variables. Econometrically, a seemingly unrelated regression (SUR) model is applied which accommodates a simultaneous estimation of various equations and accounts for the likely correlation of the land-use equations.

In Chapter 3, which addresses research objective two, I investigate the factors that determine the inclusion of villages into the oil palm sector through contract farming schemes and evaluate the impact of this form of market integration on economic development. Since the adoption of contract farming arrangements is conditional on an investor who visits a village to propose a contract, I investigate contract adoption at the village level as a two-step model. In particular, I employ a bivariate model with selection. Furthermore, to examine the effects of market integration on economic development at the village level I use a wealth index (WI) that is based on shares of

\footnotetext{
${ }^{3}$ Further details on the sampling strategy and a detailed list of the selected villages can be found in Faust et al. (2013). Note that the sampling framework was jointly established with other sub-projects within the CRC.
} 
households owning various assets as a proxy. A recall dataset is used to analyze wealth effects over time, in particular between 2002 and 2012.

In Chapter 4, I explore the effects of market integration on village institutions. Specifically, I want to understand how contract farming schemes, that introduce institutional changes towards more formalized and anonymous business relationships, affect generalized trust preferences at the village level. To do so, I make use of both survey data and behavioral data elicited through a behavioral experiment. I further probe generalized trust differences between contract participants and non-contract participants who live in the same village.

Finally, Chapter 5 concludes by summarizing the overall study and presenting the key findings. I further derive policy recommendations and state the limitations of this study jointly with suggesting avenues for future research. 


\title{
Chapter 2
}

\section{Land-use Dynamics:}

\section{The Role of Policies and Socioeconomic Factors}

\begin{abstract}
We investigate land-use dynamics in Jambi, Sumatra, one of the hotspots of Indonesia's recent oil palm boom. Data from a structured village survey are used to analyze the role of socioeconomic and policy factors. Oil palm is partly grown on large plantations, but smallholders are also involved to a significant extent. We find that, in spite of considerable oil palm expansion, rubber remains the dominant crop. Most of the oil palm growth takes place on previous fallow and rubber land. Oil palm has not been a major driver of deforestation. Much of the forest in Jambi was cleared more than 20 years ago, and rubber was an established cash crop long before the oil palm boom started. However, oil palm growth occurs in locations with ongoing logging activities, so indirect effects on deforestation are possible. The Indonesian government's transmigration program of the 1980s and 1990s was instrumental for the start and spread of oil palm in Jambi. Some autochthonous villages have adopted oil palm, but adoption started later than in the villages of the transmigrants from Java and it happens at a slower pace.
\end{abstract}

\subsection{Introduction}

Recently, tropical lowland regions in many parts of the world have experienced major land-use changes. The forest area declined significantly, while the area used for agricultural production increased. In Southeast Asia in particular, the land under oil palm was expanded considerably. In Indonesia, which has been the largest palm oil producer worldwide since 2008, the oil palm area increased from 0.7 million ha in 1990 to 6.5 million ha in 2012 (FAOSTAT, 2014). Globally, the oil palm expansion is driven by 
rising demand for oil palm products for human and livestock consumption, as ingredients in the cosmetics industry, and to some extent also for biofuel (McCarthy, 2010). While oil palm has caused an economic boom in the producing regions, it has also attracted criticism on environmental and social grounds. Oil palm expansion is often held responsible for deforestation, biodiversity loss, increased greenhouse gas emissions, and conflicts over land rights between oil palm companies and local communities (Curran et al., 2004; Fitzherbert et al., 2008; Koh and Wilcove, 2008; Wilcove and Koh, 2010; Koh et al., 2011; Wicke et al., 2011; Carlson et al., 2012; Margono et al., 2012; Obidzinski et al., 2013; Dewi et al., 2013; Wheeler et al., 2013; Barnes et al., 2014). However, oil palm is not only grown on large-scale plantations. Local smallholder farmers are increasingly involved as well (Feintrenie et al., 2010a; Feintrenie et al., 2010b; Rist et al., 2010). In Indonesia, the active involvement of smallholder farmers in oil palm cultivation is part of an official government policy (Larson, 1996).

What are the drivers of the oil palm expansion and related other land-use changes at the local level? Why are the trends more pronounced in certain locations than in others? Addressing such questions could help adjust policies aimed at avoiding undesirable outcomes, but related research is scant (Nesheim et al., 2014). Several studies have analyzed land-use changes in oil palm hotspots using satellite images (Hansen et al., 2009; Koh et al., 2011; Carlson et al., 2012; Margono et al., 2012). However, while satellite images for different points in time provide reliable information about the types of land-use changes, they cannot explain why these changes occurred. In other words, the socioeconomic and policy drivers remain unclear. Regional policies in particular are expected to play an important role for land-use changes. In Indonesia, for instance, the government has implemented the so-called transmigration program since the 1980s in which people from Java were relocated to Sumatra and other less densely populated islands and supported in oil palm cultivation and other economic activities (Larson, 1996; Fearnside, 1997; Levang, 1997). 
In this chapter, we address this knowledge gap and analyze the types and determinants of land-use changes in Indonesia. The concrete study region is the province of Jambi on the island of Sumatra, where the expansion of oil palm has been very rapid over the last 30 years. Other important land-use systems in Jambi include rubber and forest. We use data from a survey of randomly selected villages to explain land-use at a certain point in time through land-use in previous time periods and a set of socioeconomic and policy factors. We account for likely correlation between different land-use equations by using a SUR approach.

The remainder of this chapter is structured as follows. The next section provides some background of Jambi and the Indonesian government's transmigration program. After that, the village survey and the statistical approach are described, before the estimation results are presented and discussed. The last section concludes.

\subsection{Background}

\section{Land-use in Jambi province}

Located in central Sumatra, the province of Jambi has increasingly become a hotspot of oil palm cultivation during recent decades. The area under oil palm in Jambi almost quadrupled from 150,000 ha in 1996 to 550,000 ha in 2011 (Figure 4; BPS, 2012). During the same period, the area under rubber increased by only $27 \%$, from 510,000 to 650,000 ha. Despite this rapid expansion of oil palm, rubber remains the dominant crop in Jambi. We also observe a considerable increase in fallow land. Fallow land is locally often referred to as 'sleeping land', because households and communities keep this land with the intention of some future use. Fallow land is either over-logged forest or unproductive plantation land. Paddy cultivation is only observed in some pockets of Jambi with a declining trend. Primary forest land declined considerably over the last decades while the land for agricultural use expanded (Margono et al., 2012; Villamor et al., 2014). While the mountainous regions in southwestern Jambi still hold large natural 
forests, the remaining forest in the lowlands is small and nowadays largely confined to two national parks and a protected area. In addition, villages in the lowlands have shrinking patches of secondary forest at various levels of degradation.

Figure 4. Land-use change in Jambi province between 1990-2012

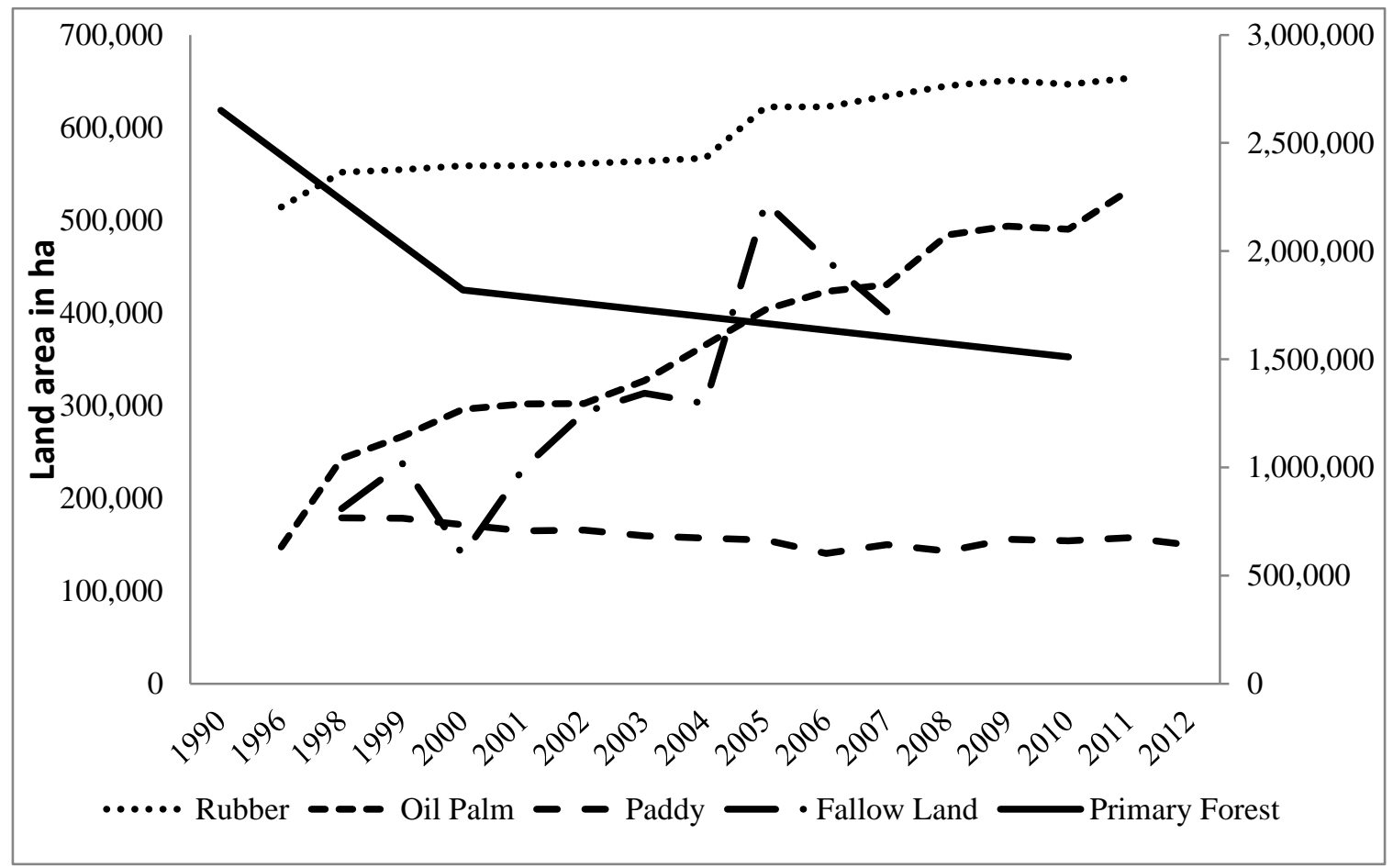

Notes: The left-hand Y-axis refers to rubber, oil palm, paddy and fallow land; the right-hand Yaxis refers to primary forest; source: Badan Pusat Statistik (BPS, 2012); Margono et al. (2012).

\section{Transmigration program}

We expect that the government's transmigration program played an important role in shaping land-use changes in Jambi. As part of this program, families from Java's densely populated areas were relocated on a voluntary basis to the so-called 'Outer Islands' Sumatra, Kalimantan, and Papua. Apart from a spatial-political rationale of Suharto's New Order Regime in achieving unity across the various ethnicities (Elmhirst, 1999), the transmigration program facilitated the government's efforts to spur economic 
development in rural areas. At the beginning of the program, in the early-1980s, transmigrants were allocated rice fields in their new homes mainly for subsistence farming. But relatively soon, transmigrants also received government support to cultivate rubber as a cash crop (Levang, 1997). From the late-1980s, the Indonesian government changed the focus and started to develop the oil palm sector. This was also the time when the first 'oil palm transmigrants' arrived in Jambi through fully government-sponsored schemes. These oil palm transmigrants were placed into newly established settlements next to large government-managed oil palm estates. Participants were allocated a piece of oil palm land (usually 2-3 ha per family) at the periphery - the plasma - of the estate. Likewise, agricultural inputs and extension services were provided by the government through a loan system (Fearnside, 1997). After loan repayment, transmigrant families could obtain a formal title for their piece of land (Murdiyarso et al., 2002). At the core of the plantation area - the inti - an oil palm mill was established, allowing the processing of the FFB within a short period after harvest. Such inti-plasma systems are often referred to NES schemes. Similar NES schemes for oil palm were soon also established with the involvement of private companies under strict contractual conditions. In exchange for land concessions and access to subsidized capital provided by the government, private companies had to guarantee the involvement of smallholder transmigrants, and sometimes also autochthonous communities. However, autochthonous communities started to be involved in oil palm schemes significantly later. For many of them, rubber is still the most important crop.

The NES schemes that were established in the 1980s and 1990s largely remained in place until now, although the overall conditions have changed. Due to the large costs and the fall of the Suharto Regime in 1998, the government gradually backed out. Today, the oil palm sector in Jambi is dominated by private companies and smallholder farmers. After 1999, the post-Suharto government implemented a decentralization process, shifting decision-making power to local authorities. Companies that wish to establish new oil palm plantations now have to negotiate directly with district governments and local communities over access to land (Larson, 1996; McCarthy, 2010). Such contracts are 
often similar to NES schemes, because communities that provide part of their land for plantation establishment may request loans and other support from companies for their own oil palm cultivation. However, most autochthonous communities do not hold formally recognized titles for their land (Barkmann et al., 2010). Hence, conflicts over land rights and contractual details are commonplace. In this respect, transmigrants who received a formally recognized land title after loan repayment have a clear advantage over the autochthonous population. Autochthonous people can also apply for formal land titles, but the administrative procedure is costly and time-consuming (Thorburn, 2004).

In addition to the contracts, an increasing number of smallholders have recently started to cultivate oil palm independently. In some cases, these are farmers whose initial contracts expired. Other independent oil palm growers never had a contract, but could access the required capital and knowledge through other channels. In our analysis, we are particularly interested to analyze recent land-use changes and possible differences between migrants and autochthonous people.

\subsection{Materials and methods}

\section{Village survey}

We carried out a village survey in the lowland regions of Jambi province that have been most affected by land-use changes over the last few decades. The five major lowland districts in Jambi are Muaro Jambi, Batang Hari, Sarolangun, Tebo, and Bungo. In each of these five districts, five sub-districts were randomly selected for the survey. For all these 25 sub-districts we compiled complete lists of villages using data from PODES. From these lists, we randomly sampled four villages in each sub-district, resulting in a total of 100 villages. Due to logistical problems, two of these villages could not be reached; the other 98 villages were visited for detailed data collection through interviews with the village leadership. The locations of these 98 sample villages are shown in the map in Figure 3. 
Data collection took place from September to December 2012. A structured questionnaire was designed for this purpose. Interviews were carried out in the local language by enumerators from Jambi University. These enumerators were trained intensively and supervised in the field by the researchers. Before visiting the villages, we made appointments with the village head, explaining the purpose of the study and asking for cooperation. We organized group interviews with several village representatives. All village heads agreed to participate in the group interviews. In addition, other village officials, such as the village secretary, village hamlet leaders, and elderly villagers were invited to participate. Usually, the group interviews were organized in the house of the village head or his/her office and lasted for three to four hours in each village. In most villages, statistical data about current and past population structures, land use, land titles, and related details are kept as hard copy or digital files, which facilitated the process of filling in the questionnaire considerably.

The survey data collected include a breakdown of the total village area by land-use systems. The village area comprises the land that village households use individually as well as communal areas and land leased out to companies. The three major land-use systems in Jambi's lowlands are rubber, oil palm, and (secondary) forest. Furthermore, villages have varying areas of fallow land and to a lesser degree also cultivate paddy. For rubber in particular, different production intensities are observed, ranging from extensive agroforestry systems (sometimes referred to as 'jungle rubber') to intensively cultivated rubber plantations. As boundaries are fluid, we do not differentiate between production intensities in the main part of the analysis. However, we test the robustness of the results by further disaggregating rubber systems in supplementary estimates. ${ }^{4}$

\footnotetext{
${ }^{4}$ In the village questionnaire, we made the distinction between perkebunan karet (rubber monoculture) and hutan karet (jungle rubber/rubber agroforest). Yet we realized that the definitions are not uniform. In several villages, the term hutan karet was also used when only a few fruit trees had been planted into a rubber monoculture plantation. This might potentially bias the results of the disaggregated analysis. Another concern may be related to the distinction between forest and rubber agroforest. Ekadinata and Vincent (2011) noted that it is hard to distinguish complex rubber agroforests from secondary forests in satellite images. This problem is less relevant in our context, because we use people's responses from the
} 
In the group interviews, we asked for the land-use details in all villages as well as for village socioeconomic data, such as population structure, infrastructure conditions, and types of institutions. Furthermore, we asked the group of respondents for estimates on the share of village households owning certain assets and using particular technologies. All variables were captured for 2012, representing the status quo at the time of the interviews. Moreover, we asked the same questions also for 2002 and 1992, thus covering changes over a period of 20 years. The data for 2002 and 1992 were recalled by the villagers, which may potentially lead to lower data accuracy. However, for many of the variables data were available from statistical records kept at the village level. For other variables, group discussions proved to be very useful, as collective memories are often better than individual ones. While some measurement error is possible, we are confident that the data quality is sufficient to reveal important trends. These data are used in the statistical analysis as explained below.

\section{Modeling land-use dynamics}

We want to understand how land-use in the lowlands of Jambi changed during the last 20 years and what factors contributed to these changes. To model land-use dynamics, we specified the following system of equations:

$$
\begin{aligned}
& O P_{v t}=\alpha_{1}+\beta_{1} 2012_{v}+\gamma_{1}^{\prime} L U_{v t-10}+\delta_{1} L_{v t}+\rho_{1}^{\prime} S_{v t-10}+\varepsilon_{1 v}+\mu_{1 v t}, \\
& R U_{v t}=\alpha_{2}+\beta_{2} 2012_{v}+\gamma_{2}^{\prime} L U_{v t-10}+\delta_{2} L_{v t}+\rho_{2}^{\prime} S_{v t-10}+\varepsilon_{2 v}+\mu_{2 v t} \\
& F O_{v t}=\alpha_{3}+\beta_{3} 2012_{v}+\gamma_{3}^{\prime} L U_{v t-10}+\delta_{3} L_{v t}+\rho_{3}^{\prime} S_{v t-10}+\varepsilon_{3 v}+\mu_{3 v t}
\end{aligned}
$$

where $O P_{v t}$ is the oil palm area, $R U_{v t}$ the rubber area, and $F O_{v t}$ the forest area in village $v$ at time $t$, all expressed in ha. $L U_{v t-10}$ is a vector of land-use systems in the same village 10 years earlier. $L_{v t}$ is the total area in village $v$ at time $t$, which we include on 
the right-hand side to control for villages of different land size. The total village area includes land under forest, rubber, oil palm, and fallow, as well as other uses such as residential areas and food crop cultivation (paddy, fruits, vegetables). $S_{v t-10}$ is a vector of village-level socioeconomic variables; to avoid endogeneity we use lagged values for time period $t-10$. $\varepsilon$ captures the time-invariant unobserved factors in each equation that may affect land use. To control for such unobserved factors, we include village fixed effects. $\mu_{v t}$ in each equation is the idiosyncratic error term that changes over time and across villages. Time $t$ includes the observations for 2002 and 2012. To control for a time trend, we include a year dummy for 2012. Accordingly, $t-10$ includes the observations for 1992 and 2002.

The vector of lagged land-use systems $\left(L U_{v t-10}\right)$ includes oil palm, rubber, forest, and fallow land, all expressed in ha. The estimated coefficients for these land-use variables $\left(\gamma^{\prime}\right)$ help us to identify land-use trends. For instance, a positive and significant coefficient for the lagged forest area in the oil palm equation would suggest that the oil palm expansion contributes directly to deforestation. A positive and significant coefficient for the lagged oil palm area in the oil palm equation would suggest a path-dependency towards specialization at the village level.

In terms of socioeconomic variables as part of vector $S_{v t-10}$, we build on the land-use change and deforestation literature (e.g., Lambin et al., 2003; Mitsuda and Ito, 2011). We use village characteristics such as population density, distance to road, share of households with formal land titles, and share of households using certain types of technologies such as mineral fertilizers. Furthermore, wealth may play an important role for land-use change decisions, such as switching towards oil palm (Feintrenie et al., 2010b). We constructed a wealth index - WI - at the village level, building on data on the percentage of households owning assets such as cars, television, fridges, and mobile phones. The WI was calculated using principle component analysis, as described in Sahn and Stifel (2003). It is normalized in the 0-1 range, with higher values representing higher village-level wealth. 
In this model, equations (1) to (3) are not independent. When total land is limited, landuse change decisions from one system to another are made simultaneously. We therefore estimate this system of equations with the SUR approach. The SUR model produces consistent estimates also when there is error term correlation (Cameron and Trivedi, 2009, p.162). The Breusch-Pagan test is used to test for error term correlation. We estimate the SUR model with a feasible generalized least squares estimator, which requires the equations not to have identical sets of regressors (Cameron and Trivedi, 2009, p.163). We therefore exclude individual variables from $L U_{v t-10}$ in equations (2) and (3).

\section{Modeling the role of migration}

In addition to other socioeconomic factors, we are interested to better understand the role of migration. As discussed above, transmigrants from Java were the first smallholders to start oil palm cultivation in Jambi. We use a transmigrant dummy for villages that were initiated as part of the government's transmigration program. Moreover, we use a dummy for villages that were started by spontaneous migrants. Spontaneous migrants may also be from Java, or from other parts of Sumatra, who came to Jambi without being part of the transmigration program. The reference group consists of villages that were founded by autochthonous people, mainly the Melayu Jambi. Autochthonous people are characterized by a more sedentary lifestyle. These dummies refer to the migration status of villages, not necessarily other ethnic characteristics of the village population. Nowadays, most villages in Jambi comprise a mixture of ethnicities due to marriages and additional migration. To capture the possible role of ethnical homogeneity for land-use changes, we use a variable measuring the population share of the dominant ethnicity in a particular village.

The two migration dummies (spontaneous migration and transmigration) are closely correlated with the village fixed effects, leading to collinearity problems in estimation. 
Hence, we first estimate a model with village fixed effects but without migration dummies. In a second specification, we include the migration dummies and exclude the village fixed effects. In additional specifications, we test whether spontaneous migration and transmigration also affect the coefficients of the other variables by interacting with $L U_{v t-10}$ and $S_{v t-10}$. For instance, it might be possible that the availability of forest land affects oil palm expansion differently in autochthonous and migrant villages. Similarly, the role of wealth or land titles for land-use change decisions may differ by migration background. Including all possible interaction terms in one specification would inflate the standard errors due to low degrees of freedom. We therefore use a sequence of additional specifications, including different groups of interaction terms always along with the other control variables.

\subsection{Results}

\section{Descriptive statistics}

Table 1 shows descriptive statistics for our sample of villages for the three points in time: 1992, 2002, and 2012. Of the 98 villages for which we had collected data in 2012, 8 villages had to be dropped for the following reasons. In five cases, the villages had recently emerged through separation from another village; for these five villages, we could collect data for 2012 but not for the previous time periods. Since we want to model trends over time, using these five villages in this analysis did not make sense. Three other villages had to be dropped because of missing data and stark outliers for some of the variables. We therefore remain with 90 village observations. These 90 villages include a few that were newly founded during the last 20 years (e.g. through a new transmigration settlement). Therefore, the numbers of observations are somewhat smaller in 1992 and 2002 than in 2012. When villages were newly founded and did not emerge through separation from another village, we decided to keep them in order not to further reduce 
the sample size. We include an additional dummy variable into the model to control for possible differences between old and newly founded villages.

Table 1. Village descriptive statistics

\begin{tabular}{|c|c|c|c|c|c|c|}
\hline \multirow{2}{*}{ Land-use variables } & \multicolumn{2}{|c|}{$\begin{array}{c}1992 \\
(\mathrm{~N}=72) \\
\end{array}$} & \multicolumn{2}{|c|}{$\begin{array}{c}2002 \\
(\mathrm{~N}=76)\end{array}$} & \multicolumn{2}{|c|}{$\begin{array}{c}2012 \\
(\mathrm{~N}=90) \\
\end{array}$} \\
\hline & & & & & & \\
\hline Oil palm (ha) & 61.5 & $(225.67)$ & 269.09 & $(543.52)$ & 565.78 & $(780.75)$ \\
\hline Rubber (ha) & 2387.65 & $(6821.96)$ & 2435.63 & $(6753.58)$ & 2334.12 & $(6254.25)$ \\
\hline Forest (ha) & 1417.49 & $(2615.41)$ & 866.05 & $(1978.17)$ & 779.11 & $(1872.04)$ \\
\hline Fallow (ha) & 660.13 & $(1155.75)$ & 669.26 & $(1157.21)$ & 662.61 & $(1137.99)$ \\
\hline Total land (ha) & 5057.72 & $(7640.09)$ & 4889.79 & $(7417.02)$ & 4558.11 & $(6951.48)$ \\
\hline \multicolumn{7}{|l|}{ Migration dummies } \\
\hline Autochthonous village (d) & 0.611 & $(0.491)$ & 0.592 & $(0.495)$ & 0.578 & $(0.497)$ \\
\hline Spontaneous migrant village (d) & 0.167 & $(0.375)$ & 0.158 & $(0.367)$ & 0.167 & $(0.375)$ \\
\hline Transmigrant village (d) & 0.222 & $(0.418)$ & 0.251 & $(0.436)$ & 0.256 & $(0.439)$ \\
\hline \multicolumn{7}{|l|}{ Socioeconomic variables } \\
\hline Population density (pop/ha) & 0.486 & $(0.565)$ & 0.761 & $(0.818)$ & 1.006 & $(1.039)$ \\
\hline Distance to road $(\mathrm{km})$ & 4.244 & $(14.31)$ & 2.181 & $(7.351)$ & 1.266 & $(5.427)$ \\
\hline Chemical fertilizer (share of households) & 0.186 & $(0.342)$ & 0.328 & $(0.381)$ & 0.496 & $(0.366)$ \\
\hline Wealth index $(0-1)$ & 0.151 & $(0.163)$ & 0.479 & $(0.291)$ & 0.724 & $(0.131)$ \\
\hline Dominant ethnicity (share of households) & 0.762 & $(0.327)$ & 0.787 & $(0.273)$ & 0.806 & $(0.167)$ \\
\hline Land title (share of households) & 0.213 & $(0.356)$ & 0.351 & $(0.393)$ & 0.458 & $(0.349)$ \\
\hline
\end{tabular}

Note: Mean values are shown with standard deviations in parentheses.

On average, in 2012 villages had a total land area of 4558 ha, of which $51 \%$ was covered with rubber (Table 1). This underlines that rubber is still the dominant agricultural crop in Jambi. The rest of the village land is under secondary forest (17\%), fallow (15\%), oil palm (12\%), and other uses (5\%), including residential areas and food crops, such as paddy, fruits, and vegetables. However, land use changed considerably over the last 20 years. In particular, the oil palm area has increased almost tenfold since 1992, while the forested area was nearly cut in half. The fallow area and the land under rubber did not change much in size, although nowadays rubber is often cultivated more intensively than 20 years ago. That the average fallow land did hardly change since 1992 does not mean that exactly the same pieces of land are still fallow 20 years later. As mentioned, fallow 
land is either over-logged forest or unproductive plantation land. ${ }^{5}$ Fallow is therefore a temporary state in which the land is kept available for new land-use decisions by individual households or the village community.

Table 1 also shows other village characteristics. In 2012, 58\% of the sample villages were autochthonous, 25\% were transmigrant, and $17 \%$ were spontaneous migrant villages. As expected, the proportion of transmigrant villages increased somewhat over time with new settlements being established under the government program. The data on population density suggest significant population growth over the 20-year period. Furthermore, the use of agricultural technology (chemical fertilizer) and mean wealth levels have significantly increased, and infrastructure conditions have improved since 1992.

\section{Base model estimation results}

Table 2 presents results from estimation of equations (1) to (3). The Breusch-Pagan test statistic shows that the null hypothesis of no error term correlation between the equations has to be rejected. We conclude that the SUR approach is more suitable than the ordinary least squares (OLS) estimator. The number of observations in the regressions is 180, consisting of the 90 villages observed for $t=2012$ and $t=2002$, and corresponding lagged time periods for 2002 and 1992. Not all of the villages sampled in 2012 existed in previous periods. When a village did not exist in 2002 or 1992, all variable values for these years were set to zero. To control for possible systematic differences between such new villages and older ones, we additionally include an 'old village' dummy, which takes a value of one for all villages that already existed in 1992 and zero otherwise.

\footnotetext{
${ }^{5}$ Traditionally, fallow land in Jambi was connected to swidden agriculture. However, with increasing population density and the growing role of tree crops, swidden agriculture disappeared almost completely (De Jong et al., 2001). In the village questionnaire, we attempted to avoid any confusion by defining fallow land as over-logged or unproductive plots.
} 
We first focus on the left-hand part of Table 2 (columns 1 to 3). The year dummy for 2012 in column (1) suggests that the oil palm area increased significantly, on average by 502 ha per village during the 2002-2012 period. For rubber (column 2), no such effect is observed. For the forest area (column 3), a negative time trend occurs, which is not statistically significant though. Looking at the role of lagged land-use systems, oil palm cultivation in the past contributes to further expansion of oil palm, while rubber cultivation in the past contributes to further expansion of rubber. However, the positive and significant lagged rubber coefficient in column (1) indicates that there is also some conversion of rubber to oil palm. Furthermore, fallow land in the past contributes significantly to oil palm expansion. The coefficient for lagged forest land in column (1) is not significantly different from zero, suggesting that the oil palm expansion during the last 10 years did not contribute to deforestation directly. On the other hand, the results in column (3) show that oil palm cultivation and fallow land in the past both contributed to declining forest land at the village level.

Turning to the effect of the socioeconomic variables, we observe that old villages that already existed in 1992 increased the oil palm area significantly less than newly established villages. We further find that higher population density in the village 10 years ago is associated with less oil palm cultivation today (column 1), whereas the association between population density and forest land is insignificant (column 3). In terms of infrastructure conditions, distance to an all-season road in the past is associated with more oil palm and forest land today. Each additional $\mathrm{km}$ of distance increases the village oil palm area by 11 ha and the forest area by 38 ha. Wealth does not have a significant effect for rubber and forest land, but it does play an important role for oil palm expansion. Villages with a higher lagged WI increased their oil palm land significantly less than poorer villages. Implications of these results are discussed further below. 
Table 2. Land-use equations (SUR model)

\begin{tabular}{|c|c|c|c|c|c|c|}
\hline & $\begin{array}{c}\text { (1) } \\
\text { Oil palm }\end{array}$ & $\begin{array}{c}(2) \\
\text { Rubber }\end{array}$ & $\begin{array}{c}(3) \\
\text { Forest }\end{array}$ & $\begin{array}{c}\text { (4) } \\
\text { Oil palm }\end{array}$ & $\begin{array}{c}(5) \\
\text { Rubber }\end{array}$ & $\begin{array}{c}(6) \\
\text { Forest }\end{array}$ \\
\hline Year $2012(d)$ & $\begin{array}{l}501.88 * * * \\
(85.73)\end{array}$ & $\begin{array}{l}-8.531 \\
(110.52)\end{array}$ & $\begin{array}{l}-250.31 \\
(162.94)\end{array}$ & $\begin{array}{l}224.23 * * * \\
(81.19)\end{array}$ & $\begin{array}{l}170.31 \\
(109.93)\end{array}$ & $\begin{array}{l}-40.18 \\
(158.01)\end{array}$ \\
\hline \multicolumn{7}{|l|}{ Land-use variables } \\
\hline Oil palm ${ }_{\mathrm{t}-10}$ & $\begin{array}{l}0.252 * * * \\
(0.095)\end{array}$ & $\begin{array}{l}-0.027 \\
(0.115)\end{array}$ & $\begin{array}{l}-0.745^{* * *} \\
(0.175)\end{array}$ & $\begin{array}{l}0.951 * * * \\
(0.092)\end{array}$ & $\begin{array}{l}-0.184 \\
(0.123)\end{array}$ & $\begin{array}{l}-0.427 * * \\
(0.172)\end{array}$ \\
\hline Rubber $_{t-10}$ & $\begin{array}{l}0.304 * * * \\
(0.074)\end{array}$ & $\begin{array}{l}0.457 * * * \\
(0.108)\end{array}$ & & $\begin{array}{l}-0.077 * * * \\
(0.028\end{array}$ & $\begin{array}{l}1.024 * * * \\
(0.026)\end{array}$ & \\
\hline Forest $_{t-10}$ & $\begin{array}{l}0.002 \\
(0.032)\end{array}$ & & $\begin{array}{l}0.085 \\
(0.069)\end{array}$ & $\begin{array}{l}0.015 \\
(0.029)\end{array}$ & & $\begin{array}{l}0.522 * * * \\
(0.037)\end{array}$ \\
\hline Fallow $_{\mathrm{t}-10}$ & $\begin{array}{l}0.359 * * * \\
(0.081)\end{array}$ & $\begin{array}{l}-0.194 * \\
(0.105)\end{array}$ & $\begin{array}{l}-0.693 * * * \\
(0.145)\end{array}$ & $\begin{array}{l}-0.126 * * * \\
(0.044)\end{array}$ & $\begin{array}{l}0.209 * * * \\
(0.052)\end{array}$ & $\begin{array}{l}-0.001 \\
(0.067)\end{array}$ \\
\hline Total land ${ }_{\mathrm{t}}{ }^{\mathrm{a}}$ & $\begin{array}{l}-0.053 \\
(0.036)\end{array}$ & $\begin{array}{l}0.255^{* * * *} \\
(0.047)\end{array}$ & $\begin{array}{l}0.304 * * * \\
(0.071)\end{array}$ & $\begin{array}{l}0.099 * * * \\
(0.027)\end{array}$ & $\begin{array}{l}-0.021 \\
(0.024)\end{array}$ & $\begin{array}{l}0.006 \\
(0.011)\end{array}$ \\
\hline \multicolumn{7}{|l|}{ Socioeconomic variables } \\
\hline Old village $(\mathrm{d})$ & $\begin{array}{l}-608.46^{* *} \\
(283.15)\end{array}$ & $\begin{array}{l}-280.62 \\
(368.22)\end{array}$ & $\begin{array}{l}38.29 \\
(544.39)\end{array}$ & $\begin{array}{l}8.326 \\
(104.89)\end{array}$ & $\begin{array}{l}-194.31 \\
(142.94)\end{array}$ & $\begin{array}{l}-167.38 \\
(205.14)\end{array}$ \\
\hline Population density $\mathrm{t}_{\mathrm{t}-10}(\mathrm{pop} / \mathrm{ha})$ & $\begin{array}{l}-201.92 * \\
(118.76)\end{array}$ & $\begin{array}{l}-57.38 \\
(155.43)\end{array}$ & $\begin{array}{l}284.37 \\
(224.69)\end{array}$ & $\begin{array}{l}-59.44 \\
(61.06)\end{array}$ & $\begin{array}{l}-28.67 \\
(83.06)\end{array}$ & $\begin{array}{l}-30.81 \\
(119.24)\end{array}$ \\
\hline Distance to $\operatorname{road}_{\mathrm{t}-10}(\mathrm{~km})$ & $\begin{array}{l}10.68 * * \\
(4.816)\end{array}$ & $\begin{array}{l}-6.778 \\
(6.245)\end{array}$ & $\begin{array}{l}38.394 * * * \\
(9.332)\end{array}$ & $\begin{array}{l}-13.51 * * * \\
(3.569)\end{array}$ & $\begin{array}{l}0.871 \\
(4.778)\end{array}$ & $\begin{array}{l}24.58 * * * \\
(6.969)\end{array}$ \\
\hline Chemical fertilizer $_{\mathrm{t}-10}($ share of $\mathrm{HH})$ & $\begin{array}{l}-46.03 \\
(144.68)\end{array}$ & $\begin{array}{l}-169.41 \\
(186.61)\end{array}$ & $\begin{array}{l}-279.29 \\
(277.29)\end{array}$ & $\begin{array}{l}-252.65 * * \\
(101.39)\end{array}$ & $\begin{array}{l}-14.11 \\
(138.47)\end{array}$ & $\begin{array}{l}276.25 \\
(195.93)\end{array}$ \\
\hline Wealth index $\mathrm{t}_{\mathrm{t}-10}$ & $\begin{array}{l}-560.54 * * * \\
(194.96)\end{array}$ & $\begin{array}{l}362.87 \\
(253.25)\end{array}$ & $\begin{array}{l}-23.78 \\
(376.64)\end{array}$ & $\begin{array}{l}-141.24 \\
(162.89)\end{array}$ & $\begin{array}{l}-218.15 \\
(222.21)\end{array}$ & $\begin{array}{l}31.66 \\
(318.62)\end{array}$ \\
\hline Land title $_{\mathrm{t}-10}($ share of $\mathrm{HH})$ & $\begin{array}{l}176.08 \\
(132.95)\end{array}$ & $\begin{array}{l}-1.888 \\
(168.45)\end{array}$ & $\begin{array}{l}88.51 \\
(255.39)\end{array}$ & $\begin{array}{l}52.42 \\
(108.59)\end{array}$ & $\begin{array}{l}-114.11 \\
(151.47)\end{array}$ & $\begin{array}{l}14.42 \\
(217.29)\end{array}$ \\
\hline Dominant ethnicity $_{\mathrm{t}-10}($ share of $\mathrm{HH})$ & $\begin{array}{l}-237.97 \\
(-238.07)\end{array}$ & $\begin{array}{l}-56.73 \\
(-300.53)\end{array}$ & $\begin{array}{l}536.13 \\
(446.86)\end{array}$ & $\begin{array}{l}-92.13 \\
(111.05)\end{array}$ & $\begin{array}{l}-41.65 \\
(153.17)\end{array}$ & $\begin{array}{l}-96.08 \\
(220.57)\end{array}$ \\
\hline Spontaneous migrant village (d) & & & & $\begin{array}{l}62.76 \\
(100.66)\end{array}$ & $\begin{array}{l}-389.45 * * * \\
(137.57)\end{array}$ & $\begin{array}{l}-318.55^{*} \\
(191.85)\end{array}$ \\
\hline Transmigrant village (d) & & & & $\begin{array}{l}287.53 * * * \\
(106.57)\end{array}$ & $\begin{array}{l}-42.89 \\
(145.68)\end{array}$ & $\begin{array}{l}-283.45 \\
(203.51)\end{array}$ \\
\hline Constant & $\begin{array}{l}-646.19 * \\
(387.19)\end{array}$ & $\begin{array}{l}-168.45 \\
(502.89)\end{array}$ & $\begin{array}{l}396.27 \\
(746.53)\end{array}$ & $\begin{array}{l}94.84 \\
(120.84)\end{array}$ & $\begin{array}{l}183.31 \\
(183.54)\end{array}$ & $\begin{array}{l}181.65 \\
(225.73)\end{array}$ \\
\hline Village fixed effects & YES & YES & YES & NO & NO & $\mathrm{NO}$ \\
\hline Observations & 180 & 180 & 180 & 180 & 180 & 180 \\
\hline $\mathrm{R}^{2}$ & 0.87 & 0.99 & 0.91 & 0.58 & 0.99 & 0.71 \\
\hline Breusch-Pagan independence test $\left(\mathrm{chi}^{2}\right)$ & & $51.68 * * *$ & & & $19.01 * * *$ & \\
\hline
\end{tabular}

Notes: Estimation coefficients are shown with standard errors in parentheses. All land-use variables are expressed in ha. HH, households. *** Significant at the $1 \%$ level. ** Significant at the 5\% level. * Significant at the $10 \%$ level. ${ }^{a}$ Total land comprises the total village area, including oil palm, rubber, forest, and fallow land, as well as residential areas and food crops such as paddy, fruits, and vegetables. 


\section{Results on the role of migration}

We now present the results regarding the role of migration in more detail by including migration dummies for villages that were started by spontaneous migrants and transmigrants as explanatory variables. Results of this expanded model are shown in columns (4) to (6) of Table 2. Controlling for other factors, transmigrant villages have significantly larger oil palm areas than autochthonous villages that constitute the reference group (column 4). However, the transmigrant dummy has no significant effect on rubber and forest areas (columns 5 and 6). As explained, early transmigrants were supported in rubber cultivation. Yet spontaneous migrant villages have significantly less rubber than autochthonous villages. They also tend to have less forest land.

The other coefficients of the land-use and socioeconomic variables are also affected, which is largely due to the exclusion of village fixed effects in columns (4) to (6). As explained, the joint inclusion of migration dummies and village fixed effects causes collinearity problems. Differences in the coefficients with and without village fixed effects should not be overinterpreted. Nonetheless, it appears that migration might have more systematic effects on land-use change that cannot be fully captured with the two migration dummies alone. We therefore, interact these dummies with the major land-use and other socioeconomic variables to gain further insights. As described above, we use a sequential approach and estimate the model separately with different groups of interaction terms included. Results of these additional specifications are shown in Tables 3 and 4.

In Table 3, we analyze in how far the effects of previous land-use variables differ between autochthonous and migrant villages. Part A of the Table reveals that each ha of oil palm 10 years ago contributes to 0.19 ha of additional oil palm today (column 1 ). This effect is smaller than the one observed in column (1) of Table 2; in Table 3 it only refers to autochthonous villages because we now include interaction terms with the two migration dummies. The significant coefficient for the transmigrant interaction shows 
Table 3. Model results with interactions between migration dummies and land-use systems (SUR model)

\begin{tabular}{|c|c|c|c|c|}
\hline & & $\begin{array}{c}(1) \\
\text { Oil palm }\end{array}$ & $\begin{array}{c}(2) \\
\text { Rubber } \\
\end{array}$ & $\begin{array}{c}(3) \\
\text { Forest }\end{array}$ \\
\hline \multirow{3}{*}{$A$} & Oilpalm ${ }_{\mathrm{t}-10}$ & $\begin{array}{l}0.188^{*} \\
(0.101)\end{array}$ & $\begin{array}{l}-0.054 \\
(0.123)\end{array}$ & $\begin{array}{l}-0.679 * * * \\
(0.193)\end{array}$ \\
\hline & Spontaneous $*$ oil palm $\mathrm{t}_{\mathrm{t}-10}$ & $\begin{array}{l}0.189 \\
(0.404)\end{array}$ & $\begin{array}{l}-0.121 \\
(0.532)\end{array}$ & $\begin{array}{l}-0.097 \\
(0.798)\end{array}$ \\
\hline & Transmigrant $*$ oil palm $\mathrm{t}_{\mathrm{t}-10}$ & $\begin{array}{l}0.481^{*} \\
(0.291)\end{array}$ & $\begin{array}{l}0.261 \\
(0.387)\end{array}$ & $\begin{array}{l}-0.465 \\
(0.572)\end{array}$ \\
\hline \multirow{3}{*}{ B } & Rubber $_{t-10}$ & $\begin{array}{l}0.231 * * * \\
(0.077)\end{array}$ & $\begin{array}{l}0.581 * * * \\
(0.112)\end{array}$ & \\
\hline & Spontaneous $*$ rubber $_{\mathrm{t}-10}$ & $\begin{array}{l}0.484 * * * \\
(0.171)\end{array}$ & $\begin{array}{l}-0.797 * * * \\
(0.258)\end{array}$ & \\
\hline & Transmigrant $*$ rubber $_{\mathrm{t}-10}$ & $\begin{array}{l}0.447 \\
(0.421)\end{array}$ & $\begin{array}{l}-0.648 \\
(0.637)\end{array}$ & \\
\hline \multirow{3}{*}{$\mathrm{C}$} & Forest $_{\mathrm{t}-10}$ & $\begin{array}{l}0.003 \\
(0.032)\end{array}$ & & $\begin{array}{l}0.083 \\
(0.061)\end{array}$ \\
\hline & Spontaneous $*$ forest $_{\mathrm{t}-10}$ & $\begin{array}{l}-0.404 * * \\
(0.169)\end{array}$ & & $\begin{array}{l}-0.028 \\
(0.326)\end{array}$ \\
\hline & Transmigrant $*$ forest $_{\mathrm{t}-10}$ & $\begin{array}{l}0.032 \\
(0.407)\end{array}$ & & $\begin{array}{l}-1.317 * \\
(0.795)\end{array}$ \\
\hline \multirow{7}{*}{ D } & Fallow $_{\mathrm{t}-10}$ & $\begin{array}{l}0.376^{* * * *} \\
(0.082)\end{array}$ & $\begin{array}{l}-0.229 * * \\
(0.106)\end{array}$ & $\begin{array}{l}-0.731 * * * \\
(0.151)\end{array}$ \\
\hline & Spontaneous $*$ fallow $_{\mathrm{t}-10}$ & $\begin{array}{l}-0.243 \\
(0.311)\end{array}$ & $\begin{array}{l}0.634 * \\
(0.401)\end{array}$ & $\begin{array}{l}0.552 \\
(0.597)\end{array}$ \\
\hline & Transmigrant $*$ fallow $_{\mathrm{t}-10}$ & $\begin{array}{l}-0.695 \\
(0.787)\end{array}$ & $\begin{array}{l}1.259 \\
(1.013)\end{array}$ & $\begin{array}{l}0.489 \\
(1.522)\end{array}$ \\
\hline & Land-use controls & YES & YES & YES \\
\hline & Socioeconomic controls & YES & YES & YES \\
\hline & Village fixed effects & YES & YES & YES \\
\hline & Observations & 180 & 180 & 180 \\
\hline
\end{tabular}

Notes: Estimation coefficients are shown with standard errors in parentheses. All land-use variables are expressed in ha. Parts A, B, C, and D were estimated in separate regressions. All regressions contain a year 2012 dummy and the same land-use and socioeconomic variables as in Table 2; these other variables are not shown here for brevity. *** Significant at the $1 \%$ level. ** Significant at the $5 \%$ level. * Significant at the $10 \%$ level. 
Table 4. Model results with interactions between migration dummies and other socioeconomic variables (SUR model)

\begin{tabular}{|c|c|c|c|c|}
\hline & & $\begin{array}{c}(1) \\
\text { Oil palm }\end{array}$ & $\begin{array}{c}(2) \\
\text { Rubber }\end{array}$ & $\begin{array}{c}(3) \\
\text { Forest } \\
\end{array}$ \\
\hline \multirow{3}{*}{ A } & Population density $\mathrm{t}_{\mathrm{t}-10}$ & $\begin{array}{l}-437.38 * * * \\
(177.01)\end{array}$ & $\begin{array}{l}83.75 \\
(231.52)\end{array}$ & $\begin{array}{l}595.66^{*} \\
(341.31)\end{array}$ \\
\hline & Spontaneous $*$ population density $\mathrm{t}_{\mathrm{t}-10}$ & $\begin{array}{l}150.15 \\
(260.95)\end{array}$ & $\begin{array}{l}-244.94 \\
(340.75)\end{array}$ & $\begin{array}{l}-349.79 \\
(509.12)\end{array}$ \\
\hline & Transmigrant $*$ population density $\mathrm{t}_{\mathrm{t}-10}$ & $\begin{array}{l}446.48 * * \\
(226.64)\end{array}$ & $\begin{array}{l}-208.74 \\
(295.53)\end{array}$ & $\begin{array}{l}-532.04 \\
(442.28)\end{array}$ \\
\hline \multirow{3}{*}{ B } & Distance to road $t-10$ & $\begin{array}{l}9.747 \\
(6.577)\end{array}$ & $\begin{array}{l}-12.35 \\
(8.325)\end{array}$ & $\begin{array}{l}83.52 * * * \\
(11.63)\end{array}$ \\
\hline & Spontaneous $*$ distance to $\operatorname{road}_{\mathrm{t}-10}$ & $\begin{array}{l}-10.54 \\
(22.64)\end{array}$ & $\begin{array}{l}-45.64 * \\
(29.05)\end{array}$ & $\begin{array}{l}-27.73 \\
(39.95)\end{array}$ \\
\hline & Transmigrant $*$ distance to $\operatorname{road}_{\mathrm{t}-10}$ & $\begin{array}{l}2.698 \\
(8.669)\end{array}$ & $\begin{array}{l}14.23 \\
(11.14)\end{array}$ & $\begin{array}{l}-89.73 * * * \\
(15.32)\end{array}$ \\
\hline \multirow{3}{*}{$\mathrm{C}$} & Wealth index $\mathrm{x}_{\mathrm{t}-10}$ & $\begin{array}{l}-725.22 * * * \\
(224.93)\end{array}$ & $\begin{array}{l}604.08 * * \\
(291.25)\end{array}$ & $\begin{array}{l}-150.27 \\
(436.54)\end{array}$ \\
\hline & Spontaneous * wealth index $\mathrm{x}_{\mathrm{t}-10}$ & $\begin{array}{l}326.03 \\
(287.24)\end{array}$ & $\begin{array}{l}-693.42 * \\
(371.05)\end{array}$ & $\begin{array}{l}284.47 \\
(559.47)\end{array}$ \\
\hline & Transmigrant $*$ wealth index $\mathrm{x}_{\mathrm{t}-10}$ & $\begin{array}{l}329.98 \\
(281.44)\end{array}$ & $\begin{array}{l}-309.06 \\
(363.47)\end{array}$ & $\begin{array}{l}228.52 \\
(547.47)\end{array}$ \\
\hline \multirow{7}{*}{$\mathrm{D}$} & Land titles $_{\mathrm{t}-10}$ & $\begin{array}{l}-1359.02 * * \\
(601.18)\end{array}$ & $\begin{array}{l}-188.71 \\
(483.02)\end{array}$ & $\begin{array}{l}1675.56 \\
(1088.21)\end{array}$ \\
\hline & Spontaneous $*$ land titles $\mathrm{t}_{\mathrm{t}-10}$ & $\begin{array}{l}1768.16 * * * \\
(657.96)\end{array}$ & $\begin{array}{l}611.52 \\
(613.52)\end{array}$ & $\begin{array}{l}-1510.26 \\
(1223.82)\end{array}$ \\
\hline & Transmigrant $*$ land titles $\mathrm{t}_{\mathrm{t}-10}$ & $\begin{array}{l}1552.54 * * * \\
(611.01)\end{array}$ & $\begin{array}{l}136.01 \\
(506.91)\end{array}$ & $\begin{array}{l}-1682.98 \\
(1115.01)\end{array}$ \\
\hline & Land-use controls & YES & YES & YES \\
\hline & Socioeconomic controls & YES & YES & YES \\
\hline & Village fixed effects & YES & YES & YES \\
\hline & Observations & 180 & 180 & 180 \\
\hline
\end{tabular}

Notes: Estimation coefficients are shown with standard errors in parentheses. All land-use variables are expressed in ha. Parts A, B, C, and D were estimated in separate regressions. All regressions contain a year 2012 dummy and the same land-use and socioeconomic variables as in Table 2; these other variables are not shown here for brevity. *** Significant at the $1 \%$ level. ** Significant at the $5 \%$ level. * Significant at the $10 \%$ level. 
that the lagged oil palm effect is larger among transmigrants as compared to the base category of autochthonous villages. The combined effect for transmigrant villages is derived as the sum of both coefficients, in this case $0.19+0.48=0.67$. Part B reveals significant differences also in the effect of lagged rubber land on oil palm expansion between autochthonous and migrant villages (column 1). Lagged rubber land has a positive effect in all village types, suggesting significant conversion of rubber to oil palm. But the effect is much stronger in migrant villages, and especially among spontaneous migrants. On the other hand, lagged rubber land contributes to more future rubber only in autochthonous villages (column 2).

Parts $\mathrm{C}$ and $\mathrm{D}$ in Table 3 show differential effects between village types for lagged forest and fallow land. In spontaneous migrant villages, there seems to be significant conversion of forest into oil palm land - an effect that is not observed in autochthonous and transmigrant villages. Past fallow land is associated with more future oil palm and less future rubber and forest land in autochthonous villages. Most of the interaction terms are not significant, suggesting that fallow land plays a similar role also in spontaneous migrant and transmigrant villages.

Table 4 shows results with interaction terms between the migration dummies and other socioeconomic factors. Part A reveals that higher population density in the past is associated with significantly smaller oil palm areas in autochthonous villages. The effect seems to be similar in spontaneous migrant villages, but not in transmigrant villages. The combined effect in transmigrant villages is close to zero $(-437.38+446.48=9.10)$, suggesting that oil palm expansion in these villages occurs independent of population density.

Part B of Table 4 shows that an increase of lagged road distance is positively associated with forest land in autochthonous villages. However, the same effect is not observed in transmigrant villages; in the transmigration program, new villages were sometimes deliberately established in remoter areas. Also for wealth, we observe notable differences 
between migrant and autochthonous villages (part $\mathrm{C}$ ). Above we found that lagged wealth is associated with less oil palm expansion. We now see that this effect only holds for autochthonous villages, where wealth contributes to less oil palm and more rubber land. For the migrant villages, the combined wealth effects are not statistically significant.

Finally, part D of Table 4 reveals interesting results for the role of land titles. The variable land title is measured as the share of households in the village holding a land title. A larger lagged share of households with land titles is associated with further oil palm expansion in transmigrant and spontaneous migrant villages. In contrast, in autochthonous villages the lagged share of households with land titles has a negative effect on oil palm cultivation. We discuss these results and their implications in more detail further below.

\section{Robustness checks}

In this subsection, we test whether the main results also hold with some changes in model specification. For this purpose, we use the model shown in Table 2 with village fixed effects (columns 1-3) as the base and introduce several changes, as described in the following.

First, we examine whether differentiating between different rubber production systems would affect the results. As described above, rubber is cultivated with different intensities, including monoculture plantations and rubber agroforests. Boundaries are not always clear-cut, so that in the base model we decided to club different intensities into one single rubber variable. In an alternative specification, we distinguished further and used the lagged land under rubber plantations and rubber agroforests (as stated by villagers in the group interviews) as two separate explanatory variables. These alternative results are shown in Table A1 in the Appendix. Both variables are positive and 
significant in the oil palm equation, but the size of the coefficients differs. The results suggest that conversion to oil palm is more likely on previous rubber agroforest land than on previous monoculture rubber plantations. The other estimates are very similar to the base model results in Table 2 .

Second, location factors beyond distance to road may play a role for land-use decisions. In particular, access to an oil palm mill is important for the decision to grow oil palm, because the fruits are perishable and have to be milled within 48 hours after harvest. The only mills that exist in Jambi are those that were established by state or private plantations that also involve smallholders through NES schemes. While we do not have information about the exact distance between villages and mills for the three points in time, we know whether or not an NES contract exists in the village and when such a contract has been made. Hence, we include a contract dummy into the model as a proxy for access to an oil palm mill. ${ }^{6}$ In addition, the contract dummy is also a proxy for technical and managerial knowledge about oil palm cultivation, because contracted farmers also receive training and access to inputs. Results of this alternative specification with a contract dummy included are shown in Table A2 in the Appendix. Unsurprisingly, contracts are associated with significant oil palm expansion in the village. The other results are very similar to those in the base model.

Third, and related to the previous point, the institutional conditions under which oil palm farming occurs may affect land-use developments over time. In addition to contract farming, there are also many smallholders in Jambi who cultivate oil palm independently (Cahyadi and Waibel, 2013). This is not fully captured by the contract dummy at the village level, because contracts usually involve some but not all farmers in a village. Even in transmigrant villages, which were established as part of NES schemes, there are independent oil palm growers whose contracts have expired or who moved to the village after the transmigration program had ended. We therefore tested another model

\footnotetext{
${ }^{6}$ A contract dummy was not included in the base model, because this variable may potentially be endogenous.
} 
specification where we used the share of village oil palm land that is cultivated independently as explanatory variable. Results in Table A3 (Appendix) reveal that this variable is associated with significant growth of the oil palm area. This is plausible, because the independent oil palm land can be expanded more flexibly than the oil palm area under contract. Again, the other results are similar to those in the base model.

In terms of institutional conditions, the status of the forest land surrounding the villages may potentially affect land-use dynamics too. For instance, one might expect that state forest land (kawasan hutan) would be less prone to deforestation than forest land that is owned by the village communities or by individual households. However, while more than $70 \%$ of the national forest area in Indonesia is state forest land, this does not have a significant influence on deforestation activities at the local level. In local communities, de facto tenure is considered more important than formal land rights (Krishna et al., 2014). Moreover, in the post-New Order Regime (after 1998) customary land rights have again received increasing recognition. Against this background, we argue that not controlling for the status of the forest land does not introduce a bias to the analysis.

\subsection{Discussion}

\section{Interpretation of results}

Jambi province has undergone tremendous land-use changes over the last decades. We have analyzed the role of lagged land use on current developments and found significant path-dependencies: villages that cultivated much oil palm (rubber) in the past also expanded their oil palm (rubber) area more extensively in subsequent periods. The oil palm expansion has taken place primarily on previous fallow land, not on forest land. Hence, the increasing oil palm cultivation by smallholders has not been a major driver of deforestation. In this regard, Jambi is not representative of rainforest frontier regions. Much of the primary forest in Jambi was cleared more than 20 years ago, and rubber was an established cash crop long before the oil palm boom started. Some conversion of 
rubber to oil palm can be observed in Jambi. Such conversion is more likely for extensively cultivated agroforestry rubber than on intensive rubber plantations. This is likely due to the past investments made for establishing rubber plantations and the large foregone profits in an unproductive interim period when clearing the land and establishing a new oil palm plantation (Feintrenie and Levang, 2009).

Concerning deforestation, our results point at another path-dependency: more intensive logging and land conversion in the past are associated with more deforestation also in the future. Oil palm expansion occurs in locations with ongoing logging activities, so indirect effects on deforestation are possible. However, the results suggest that villagers in Jambi do not clear forest with the immediate intention to use the land for oil palm. This is in line with a recent study in Papua New Guinea, where Nelson et al. (2013) found that deforestation takes place without the explicit intention to grow oil palm in the future. While industrial oil palm plantations appear to play a role for deforestation (Gaveau et al., 2009; Carlson et al., 2012; Carlson et al., 2013), other extractive industries were often found to be more relevant. For large parts of Indonesia (i.e. Kalimantan, Sumatra, Papua, Sulawesi and Moloccus), Abood et al. (2014) showed that fiber plantations and logging concessions rank first and second as drivers of deforestation; according to that study the oil palm industry ranks third.

In terms of socioeconomic variables, we observe that population density has no significant effect on forest land conversion. This is noteworthy, because population pressure has often been identified as a driver of deforestation (e.g., Mertens et al., 2000; Kirby et al., 2006; Mena et al., 2006). However, DeFries et al. (2010) pointed out that urban population growth and associated increases in the demand for agricultural products are probably more important drivers of deforestation than rural population growth, as captured in our data. However, our results suggest that higher population density is associated with lower rates of oil palm expansion. This cannot be explained by differences in wealth between villages with higher and lower population density, because we have controlled for average wealth levels. We rather feel that differences in labor 
availability and labor costs may be important. Intensive rubber cultivation has much higher labor requirements than oil palm cultivation. In particular, rubber plantations require continuous labor availability for tapping the trees. In contrast, for oil palm significant labor input is required only in certain intervals for harvesting the ripe fruits. Hence, more densely populated villages with higher labor availability have lower incentives to switch to oil palm. The population density effect was found to be particularly strong in autochthonous villages.

The positive association between road distance and forest area was expected and is in line with the literature showing that better road infrastructure can contribute to deforestation (Kirby et al., 2006). Yet the positive association between road distance and oil palm area is somewhat surprising. Conventionally, one would expect that better infrastructure contributes to more cash crop cultivation (Gaveau et al., 2009). However, as mentioned, in Jambi rubber was already a major cash crop before the oil palm boom started (Feintrenie and Levang, 2009). Many of the oil palm NES schemes were deliberately established in remoter regions. These remoter regions later also benefited from infrastructure improvements, but infrastructure developments were not the trigger of the oil palm expansion.

The negative association between past village wealth and oil palm expansion may also be contrary to initial expectations. Establishing new oil palm plantations requires access to capital for buying the planting material and other inputs, and also to bridge the period of 3-5 years before the first fruits can be harvested. However, participants in oil palm NES schemes had access to subsidized loans and other support measures, so that for them limited initial wealth was not a major constraint to start oil palm cultivation. On the other hand, wealthier villages with productive rubber plantations had fewer incentives to switch to oil palm that was brought to Jambi from outside. These differences in financial incentives can also explain the observed path-dependencies that were mentioned above. ${ }^{7}$

\footnotetext{
${ }^{7}$ The negative association between wealth and oil palm expansion was found to be particularly pronounced in autochthonous villages. However, Feintrenie and Levang (2009) observed cases where wealthy
} 
In terms of the role of migration, our findings suggest that migrant villages (i.e., villages founded by the transmigration program or by spontaneous migrants) differ from autochthonous villages. Migrant villages have more oil palm land. For transmigrant villages the reason is obvious, as many of these villages were established as part of an oil palm NES scheme. For spontaneous migrants, who were not allocated any land by the government, clearing forest land is one way of getting access to an own agricultural production base. Spontaneous migrants have no rubber-growing tradition, and they migrated at a time when the oil palm boom had already started in Jambi. It is therefore not surprising that spontaneous migrants focused more on oil palm than on rubber cultivation. Like the transmigrants, many of the spontaneous migrants came from Java, so cultural similarities can be expected. Nevertheless, we found some significant differences between the two types of villages in terms of land-use dynamics (Table 3). These differences support the hypothesis that the government's transmigration program had significant long-term effects on land-use decisions.

One important benefit that transmigrants enjoy is the option to obtain formal land titles after loan repayment. Among other advantages, land titles can be used as collateral and therefore improve households' access to agricultural credit (Feder and Nishio, 1998). While transmigrants in particular received subsidies for oil palm cultivation in the beginning, these subsidized programs ceased. Many successful transmigrants who had obtained land titles have started to establish new independent oil palm plantations more recently. For spontaneous migrants, land titles were also found to be important for oil palm expansion, but spontaneous migrants either purchased titled land or they obtained a title for appropriated land through a costly application process. Spontaneous migrants do not fall under the customary law, where de facto land rights are recognized without formal titles. These customary land rights only apply to the autochthonous population. Against this background, the negative association between land titles and oil palm expansion in autochthonous villages is plausible. While autochthonous households can

individuals from autochthonous villages had invested in oil palm plantations (within NES schemes) outside their own villages. 
apply for land titles, many of them have never entered this costly procedure, unless they plan to sell their land. Hence, obtaining land titles can be considered as a strategy of autochthonous people to exit own agricultural production in the medium run, rather than investing in new oil palm plantations. Formal land transactions are increasingly observed in Jambi with autochthonous people as sellers and migrants as buyers (Krishna et al., 2014).

Traditional land rights are also important for land-use decisions from a different perspective. Many autochthonous villages still apply a matrilineal inheritance system. This system has undergone substantial transformations from communal towards individualized (single family) ownership (Otsuka et al., 2001). Clearing forest land and subsequently planting trees may be interpreted as one strategy of men to strengthen their land rights and privately claim land that was previously controlled by the community (Villamor et al., 2013).

\section{Limitations}

The analysis has shown that the use of survey data represents an effective tool to analyze land-use dynamics, especially with a view to better understanding the role of socioeconomic and policy factors. However, survey data also come with certain disadvantages. Compared to satellite images, the accuracy of the land-use data obtained from a survey is lower. This is especially true when long recall periods are used in the interviews. We tried to minimize inaccuracies to the extent possible, but differences in perception, definitions, and memories certainly play a role and cannot be ruled out completely. To describe land-use dynamics, explain the observed trends, and derive policy implications, a combination of remotely sensed land-use data with socioeconomic data obtained from surveys seems to be a promising avenue, as a growing strand of literature demonstrates (e.g. Muller and Zeller, 2002; Caviglia-Harris and Harris, 2008, De Souza Soler and Verburg, 2010). It should also be stressed that the interpretation of 
causality in our models should be done with caution. While we have tried to control for possible confounding factors, correlation between explanatory variables and error terms may still occur in some cases.

\subsection{Conclusion}

In this chapter, we have investigated land-use dynamics in the province of Jambi on the island of Sumatra, using data from a survey of randomly selected villages. Through structured interviews with village leaders we collected recall data on land use and a broad set of other village-level variables covering a period of 20 years, from 1992 to 2012. The data reveal considerable land-use changes, with a decline in forest land and a rapid expansion of oil palm. Nevertheless, rubber remains the dominant crop in Jambi. Oil palm is partly grown on large public sector or private company plantations, but smallholder farmers are also involved to a considerable extent. While it is often argued that oil palm is the main driver of deforestation, this has not been the case in Jambi in the recent past. Most of the oil palm growth takes place on previous fallow and unproductive rubber land. This land was covered with forest at some point, but it was logged and cleared without the immediate intention to grow oil palm. However, our data also show that oil palm growth occurs in locations with ongoing logging activities, so that indirect effects on deforestation are possible.

In terms of socioeconomic and policy factors, our results show that the Indonesian government's transmigration program played a key role for the start and spread of oil palm cultivation in Jambi and the significant involvement of smallholder farmers. In the transmigration program, people from densely populated islands (e.g. Java or Bali) were relocated to less populated areas in Sumatra (and elsewhere) and supported in oil palm cultivation in so-called NES schemes. Many of these schemes were established in the 1980s and 1990s in relatively remote areas. Although some autochthonous villages in Jambi are now also growing oil palm, they have started later than the transmigrant 
villages and expand their oil palm area at a slower pace. Field observations suggest that the government-supported oil palm NES schemes were beneficial for many of the transmigrant families. At the same time, the transmigrant program may have contributed to the risk of unequal developments between the transmigrant and autochthonous population. Analyzing trends and possible causes of inequality further would be an interesting area for future research.

Our results do not allow statements on whether the oil palm expansion in Jambi is good or bad. Such statements would require comprehensive analysis of the economic, social, and environmental impacts, which is beyond the scope of this study. However, our study clearly shows that socioeconomic and policy factors play an important role in explaining land-use trends at the local level. In this regard, our results go beyond spatially explicit analyses with satellite data, which often analyze land-use trajectories without explaining them. Improved understanding of socioeconomic and policy factors is an important precondition to design sustainable land-use policies. 


\title{
Chapter 3
}

\section{Contract Farming and Economic Development}

\begin{abstract}
Through contract farming schemes between cohorts of farmers and private companies the Indonesian government intended to spur rural economic development. In particular within the oil palm sector, such community-company 'partnerships' are commonplace. Yet, empirical evidence of the success of these formations remains mixed. In this chapter, we investigate the effects of contract farming on economic development at the village level. At the same time, little is understood regarding the factors that determine that cohorts of farmers sign a contract. Analyzing data from a structured village survey, we find a positive effect of contract farming schemes on economic development, in particular on village wealth. The share of farmers under contract and contract length play a significant role in this. Regarding contract adoption, we observe that contract participation is conditional on the visit of a private investor. Controlling for this conditionality, we find that villages that have no access to electricity are more likely to participate in community-company partnerships. Finally, considering the government's intention to spur rural economic development through contract farming and the positive wealth effects associated with it, we find that contract farming has not been entirely equally accessible; however, we do not find evidence that the rural poor were excluded.
\end{abstract}

\subsection{Introduction}

In the wake of increasing global demand for vegetable oil, the production of palm oil has extensively been promoted in many developing countries. At the same time, the emerging oil palm sector generated opportunities to spur rural economic development and to alleviate poverty. To achieve this, the government of Indonesia - the largest palm oil producing country worldwide - promoted 'partnership' formations between 
commercial agro-industrial plantations and local communities (Feintrenie et al., 2010a). Through contract farming arrangements that were usually made with cohorts of farmers, oil palm developed along with economic development (Susila, 2004; Zen et al., 2005). However, palm oil production has also been associated with negative environmental and social implications. For example, it has contributed to deforestation, loss of biodiversity and carbon stocks, and caused the emergence of land and contractual conflicts (Colchester et al., 2006; Fitzherbert et al., 2008; Koh and Wilcove, 2008; Hansen et al., 2009; Rist et al., 2010; Carlson et al., 2012; Margono et al., 2012). Moreover, authors have pointed out that contract farming schemes have not been equally accessible to all farmers (McCarthy, 2010). Furthermore, established contracts have been found to lack transparency and to benefit private companies more than local communities (Rist et al. 2010). But also within communities the benefits are unequally shared: richer contract farmers tend to benefit considerably more than their poorer village fellows (Cahyadi and Waibel, 2013).

Thus, the empirical evidence gives rise to suspect that community-company partnerships can have detrimental effects for those villagers who participate in contract farming. At the same time, the studies show that the emerging oil palm industry in Indonesia has potential for spurring economic development and improving livelihoods in rural areas (Rist et al., 2010; Feintrenie et al., 2010; McCarthy, 2010; Rosyani, 2011; Cahyadi and Waibel, 2013). Taken together, the findings are mixed and oftentimes largely based on case studies and descriptive analyses. A quantitative evaluation is missing in the literature.

The first objective of this chapter intends to fill the empirical gap in the literature by analyzing the effects of community-company partnerships on economic development at the village level. The unit of analysis is the village, which allows us to investigate broader implications for entire village communities that participate in communitycompany partnerships. In addition, this village-level perspective recognizes that usually cohorts of farmers participate in contract farming schemes. Rather than individual 
farmers bargaining over contract conditions, contracts are frequently negotiated at the famer cooperative or even at the village level (McCarthy and Cramb, 2009). Furthermore, the village-level analysis allows us to examine indirect effects of contract farming schemes. In this respect, the government promoted the emerging industry by investing into transportation and market infrastructure (Larson, 1996). This was likely beneficial to all villagers, contracted or not. In sum, the village-level analysis allows the investigation of direct and indirect effects of community-company partnerships on economic development.

The participation in community-company partnerships within the Indonesian oil palm industry is an obvious precondition to benefit from the supposedly positive economic effects. Within villages, at the individual level it has been reported that contract farming has not been accessible to all farmers alike (McCarthy, 2010). Perhaps, the same could be true for the inclusion into the oil palm industry across village communities. The inclusion encompasses two steps. First, an oil palm representative, or investor, targets prospective villages that are suitable for being included into the oil palm industry and proposes a contract. In a second step a decision is made, usually collectively, to accept or reject the contract offer (McCarthy and Cramb, 2009). In this chapter, the second objective is to analyze the impact of certain village-level factors on the probability contract adoption at the village level. Due to the conditionality of contract adoption on being visited by an investor, we control for the impact of certain village-level factors on investor visit. To the best of our knowledge this has not been addressed in the literature. However, better understanding the conditions that determine the inclusion and thus the formation of communal-company relationships is necessary to guide the formulation of sound rural economic policies.

The remainder of this chapter is organized as follows. In the next section we present a brief historical account of the oil palm development in Indonesia with special attention placed on contract farming in our study region. Section 3 outlines our materials and 
methods used. In Section 4 we present the descriptive and estimation results. Finally, Section 5 concludes.

\subsection{Background}

In Indonesia, the oil palm development can broadly be distinguished into two major phases: first, the government-led phase $(1970$ s - 1998) that started with the arrival of oil palm in Indonesia and, second, the market-oriented phase (1999 - present) that was initiated after the fall of Suharto's New Order regime (Larson, 1996; Zen et al., 2005; McCarthy, 2010; Budidarsono et al., 2013). In this section, we will present a brief historical account of the oil palm development in Jambi province by placing the emphasis on community-company partnerships and contract farming arrangements. ${ }^{8}$

\section{Government-led phase}

In the 1970s, the Indonesian government initiated the development of an oil palm sector. Before that time the focus was mainly on rubber production which is still the major cash crop to be found in Jambi to date. Advised by the World Bank at that time, the Indonesian government intended to spur economic development in rural areas by sponsoring smallholders (Zen et al., 2005). Apart from clearing lands and planting oil palm close to newly established state-owned oil palm plantations (so-called Perseroan Terbatas Perkebunan Nusantara), smallholders were given 2-4 ha of land and technical assistance to successfully cultivate the perennial crop. The smallholders harvested and delivered the FFB to the attached oil palm mill for further processing (Larson, 1996).

Amid the 1980s the Indonesian government intended to further stimulate the oil palm sector by gradually involving a selection of private companies. On the one hand, the

\footnotetext{
${ }^{8}$ Some of this section has already been discussed in the Introduction of this dissertation. However, in this section I provide a more detailed account of the oil palm development in Jambi province.
} 
government assumed responsibility for infrastructure development and also issued large land concessions and provided subsidized loans; in exchange, companies were required to involve smallholders into their plantation plan (Larson, 1996). These communitycompany partnerships are also referred to as Perkebunan Inti Rakyat, NES, or IntiPlasma. Typically, these had the company estate at its core (Inti) and were surrounded by plantations reserved for smallholders (Plasma; Feintrenie et al., 2010a).

To adhere to the government requirements, farmers were typically included upon surrendering a certain amount of (unproductive) land to the company. In return they received an oil palm 'package'. This comprised several services, like opening and planting of land, agricultural training in the initial 4-5 years before the oil palm trees would start yielding. Moreover, the companies provided employment at the estate. Especially during those initial 4-5 years of palm oil farming this employment was very welcome to bridge an initial income gap. Most importantly, the farmers received a developed oil palm plot on which high-yielding palm trees were planted. Furthermore, the package included technical assistance, such as fertilizers, herbicides and pesticides (Zen et al., 2005). However, farmers could either choose to work and manage the plots themselves or entrust these to the company. In the latter case operating costs are deducted from the profits generated by this plot. Sometimes the farmers decided to directly sell their land to the company and get compensated in cash (Rist et al., 2010). Finally, the package included loan schemes which the participating farmers could make use of to cover establishment and operational costs. These loans had a payback of usually 20 years (Fearnside, 1997).

This package enabled contract farmers to efficiently cultivate oil palm resulting in higher yields and, thus, higher profits compared to individual smallholders. The latter often lacked the technical knowledge needed for effective fertilizer applications and often could not access or understand the relevance of high-yielding varieties (Barlow et al., 2003). 
To guarantee smooth plantation operations, the private estate and mills required labor. Apart from employing local people, the Indonesian government involved migrants in the oil palm industry. A relocation program, called the transmigrasi program was instrumental to meet the demand for cheap labor (McCarthy, 2010). Basically, the rationale was to relocate people from over-densely populated areas, such as Java, to areas of land abundance (Fearnside, 1997). This program was fully sponsored by the government, meaning that in addition to the general contract conditions, the transmigrants usually got 2-4 ha of oil palm land, (land for) housing as well as a homegarden. In contrast to most of the officially untitled land to be found in vast parts of Sumatra, transmigrants would receive a government land title after these completed to repay the granted loans (Murdiyarso et al., 2002).

During the next phase, the Koperasi Kredit Primer untuk Anggota, the mentioned package remained the contractual basis. However, after almost one decade of directly sponsoring the oil palm sector, starting around 1995, the Indonesian government decided to gradually retreat from its active role. Rather, it started to assume a monitoring function. Instead of pushing the oil palm development through direct investments, including the transmigration program, budget constraints as well as increasing land scarcity and the emerging conflicts revolving around customary versus statutory land rights (Colchester et al., 2006) resulted in a policy shift. First, (Jambi’s) local people were increasingly included. Second, rising land scarcity led companies to seek alternative land sources. They followed a rather strategic approach: villages willing to receive a contract were obliged to establish a farmer cooperative. Functioning as an intermediary between farmers and the private companies, these cooperatives were responsible for the provision of technical assistance, manage loan schemes and most of all gathered suitable village land (Larson, 1996). This land would then collectively be handed-over to the company for estate development. Established contracts at the cooperative level were binding for all its members and once a contract was signed it was usually not possible for hesitating farmers to get contracted at a later stage (McCarthy, 2010). 
Before a contract is adopted at the village level, a company representative - whom we will refer to as investor - visits a prospective village. In more detail, the investor attends several village meetings for 'socialization' where (s)he praises the benefits oil palm cultivation is associated with, for the village as a whole, but also for participating smallholder farmers in particular. In case both parties show an interest the investor proposes a contract. At large, the components included in the package were rather fix but certain aspects (i.e. initial debt estimation, prices, interest rates) remain negotiable (Feintrenie et al., 2010a). Next, contract conditions are discussed among the villagers and, in a follow-up meeting with the investor negotiations over contract conditions take place. Finally, contract proposals are either accepted and signed, rejected, or subject to renegotiation. Usually, this process is accompanied by government officials and bank representatives. But also, oftentimes the bargaining process over contractual conditions is dominated by village elites, who, occasionally, abused their authority for personal interests (Zen et al., 2005; McCarthy et al., 2012).

\section{Market-oriented phase}

The most recent phase is the laissez-faire phase which was initiated simultaneously with the fall of the Suharto regime in 1998 and set in motion a process of liberalization. In more detail, this comprised the opening of the oil palm sector to private investment and companies and, at the same time, shifted budgetary responsibility down to the district level (McCarthy et al., 2012). Even the smallest political authority, the village, was entitled to more decision-making power over village related aspects (i.e. land, budgeting). Additionally, the rights of village communities were strengthened, especially vis-à-vis private companies and the government (Rist et al., 2010). In contrast, private companies could not benefit anymore from highly subsidized capital. As a consequence, money was borrowed from private banks charging steep interest rates. The government's initial terms to include smallholders into private estates were not binding anymore (Larson, 1996); nor was the provision of the package. Against this background and the 
increasing competition among private companies, various forms of contractual arrangements evolved. In contrast to the preceding phases, here, the degree of benefits extracted from contracts highly depended on the bargaining skills of the village elite and his/her integrity. At the same time, contractual outcomes depended on the extent companies were able to exploit their favorable position. Considering district governments faced budgetary constraints, they tended to offer companies highly beneficial terms of production. This also affected negotiations because in this phase these had to be in line with district, rather than central government, regulations (McCarthy et al., 2012). Among various forms of contractual arrangements, during this phase, farmers frequently engaged in contract farming arrangements wherein they outsourced all operations to the company in exchange for a percentage of the revenue (Casson, 2000).

This phase is also typified by an increasing amount of independent smallholder oil palm farmers. Sometimes, these are farmers with expired contracts. Usually independent oil palm farmers never had a contract but accessed the required resources from a maturing sector (e.g. improved road conditions, disseminated technical knowledge, available input and output markets). In our analysis, we control for the two major phases we discussed.

\subsection{Materials and methods}

\section{Survey design}

For this research we purposively selected 5 districts representing the lowlands of Jambi province. The lowlands are chosen since these are characterized by major agricultural transformations towards monoculture (Gatto et al., 2014). In particular we included the districts Muaro Jambi, Batang Hari, Sarolangun, Bungo and Tebo. To account for spatial variability, within each of the districts we drew a random sample of 5 sub-districts. Further, based on an extensive list of villages we took from PODES, we drew a random sample of 100 villages. However, due to logistical difficulties in the field we had to exclude 2 villages. Figure 3 depicts the map of sample villages in Jambi. 
Data collection took place between September and December 2012. Interviews were carried out by six students from Jambi University, who participated in intensive training during a two week workshop prior to survey implementation. Before visiting the villages we made appointments with the village head to inquire about his/her and other village officials' availability. We organized group interviews in which we invited key village officials (i.e. village head, secretary, group leaders, elderly people) in order to elicit data on certain village aspects, such as village assets, land-use change, demographics, technology use, contractual arrangements with companies, etc., by means of a structured survey. In general, the group interviews took three to four hours and were held in the house of the village head or his/her office. In addition to collecting data on the current status of the villages in 2012, we inquired data for past village characteristics, in particular for the years 2002 and 1992. To further guarantee the quality of the data, we invited elderly people to the interviews who have been living there already for a substantial period of time. In most villages a village 'monograph' existed with current and past socioeconomic data, such as demography, land-use, land titles, and others. In case villages had a contract farming arrangement, the details were generally easier to recall due to its drastic implications for village life.

To utilize the panel structure for this study we had to drop some observations. The reasons are mainly twofold. First, unfortunately our sample includes a few villages that did not yet exist in 1992. The second exclusion criterion was that, even though some villages existed in 1992, certain villages underwent considerable changes at a given point throughout the period of interest (1992-2012). Drastic changes in, for instance, demographic or land-use characteristics occurred when a village neighborhood separated from its mother village. Hence, the data gathered for the year 2012 do not refer to the same village 20 years ago. In sum, the sample of 78 villages was used in this study. 


\section{Analytical framework}

Before an effect of company-communal partnerships on economic development can be observed, villages need to be included in the oil palm industry. Therefore, we start the analytical framework by explaining how we model the inclusion in the oil palm industry. In the then following section we describe how we model the effect of companycommunal partnerships on economic development.

\section{Modeling inclusion in oil palm industry}

Since the adoption of a contract is conditional on being visited by an oil palm investor, we specify an econometric model that accounts for a possible sample selection bias. In comparison with a randomly selected village, villages that are visited by an investor may also be more likely to adopt a contract. Apart from the observed factors we can control for, self-selection bias is problematic if the unobserved factors are the same for investor visit and contract adoption (Cameron and Trivedi, 2009; p.556). For instance, some village elites could be better connected to the industry than elites in other villages, possibly resulting in a greater chance that an investor visits and that the village adopts a contract. To control for this we employ a bivariate probit model that allows the specification of two separate probit models with correlated error terms. A significant correlation in the errors would indicate that the estimation suffers from a selection bias.

Following Greene's (2008, p.817) notation we specified the following model:

Selection equation: $\quad y_{i}^{*}=\alpha_{1}^{\prime} x_{v 1}+\varepsilon_{i}, \quad y_{i}=1$ if $y_{i}^{*}>0, \quad y_{i}=0$ if $y_{i}^{*}<0$

Outcome equation: $\quad y_{v}^{*}=\alpha_{2}^{\prime} x_{v 2}+\varepsilon_{v}, \quad y_{v}=1$ if $y_{v}^{*}>0, \quad y_{v}=0$ if $y_{v}^{*}<0$

$$
\begin{aligned}
& \varepsilon_{i}, \varepsilon_{v} \sim B V N(0,0,1,1, \rho), \operatorname{Var}\left[\varepsilon_{i}\right]=\operatorname{Var}\left[\varepsilon_{v}\right]=1, \operatorname{Cov}\left[\varepsilon_{i}, \varepsilon_{v}\right]=\rho \\
& \left(y_{v}, x_{v 2} \text { is only observed when } y_{i}=1\right) ;
\end{aligned}
$$

where $y_{i}^{*}$ is an unobserved variable reflecting the benefits for an investor $i$ of visiting a village. Likewise, $y_{v}^{*}$ reflects the utility gain for a village $v$ if a contract is adopted at the 
village. The outcome variables $y_{i}$ and $y_{v}$ are observed variables which equal one if an investor visits a village or if a village adopts a contract, respectively. The vector $x$ comprises explanatory variables such as village size (i.e. in terms of population and land area), village accessibility (i.e. distance to an all season road, distance to oil palm mill), village infrastructure (i.e. access to electricity), village institutions (i.e. share of farmers holding government land titles), village wealth, and village type (i.e. transmigrant). The error terms $\varepsilon_{i}$ and $\varepsilon_{v}$ have a bivariate normal distribution with zero mean and a unit variance. The correlation coefficient between the disturbance terms will be estimated and is denoted with $\rho$.

In modeling village inclusion into the oil palm industry we have to take the following into account. Investors visited villages and contracts were adopted throughout the entire period from 1992-2012, and thus also within the 10 year time intervals. If we used the data for 2012 to explain contract adoption, in the analysis we would likely run into issues of reverse causality because certain village-level factors may have changed as a result of adopting a contract. Therefore, we adjusted our dataset. In case investor visit occurred in the period between 1992 and 2001, we use data for the year 1992 to explain investor visit/contract adoption. Likewise, for the villages which were visited in some year between 2002 and 2012 we make use of the data for the year 2002 to explain contract adoption.

Finally, to identify the model we need a variable that introduces nontrivial variation to the outcome equation (Cameron and Trivedi, 2009, p.558). The requirements for such a variable are the same as for instruments used in regular 'instrumental variable' estimations (IV). We identified the variable average land slope as a valid instrument. At the village level, this is measured as the share of village land characterized by a certain land slope (i.e. $1=$ flat, $\ldots, 5=$ steep). In the specific case of oil palm cultivation in Jambi it may be argued that steeper average land slopes in villages reflect to some extent the attractiveness of a given village. This is because in Jambi much of the available land that is characterized by flat slopes can be found in areas already under extensive agricultural 
cultivation (i.e. rubber). Since these are less likely transformed into oil palm (Gatto et al., 2014), investors have to seek alternative areas for oil palm cultivation. Thus, we argue that steeper average land slopes are positively correlated with the incidence of investor visit. At the same time, it is not likely that the instrument directly affects the incidence of contract adoption because of the conditionality of contract adoption on investor visit.

We want to briefly discuss our expectation regarding the impact of the explanatory variables on the outcome/selection variables. From an investor's perspective it is reasonable to visit those villages that hold much agricultural potential. Thus we predict that total village land has a positive effect on investor visit. Since more populated villages are more likely to be located in urban areas, where available land is scarce, we expect a negative correlation with investor visit. Further, the farther away a village is from an all season road, a proxy for accessibility, we predict a lower probability of being visited. These expectations are largely borrowed from the literature on land-use change (for instance Lambin et al., 2003, p. 226; Mitsuda and Ito, 2011). Furthermore, proximity to an oil palm mill is likely to predict investor visit because this would guarantee that the FFB are processed in a timely manner and would reduce transactions costs. In terms of village infrastructure, access to electricity may likely be a decisive factor for being visited, since the availability of electricity would facilitate a rapid operation commencement. Moreover, we predict government land titles to be a positive predictor for attracting investors to the village. Larger shares of households holding government land titles could imply that land disputes between villagers and the government/companies are less likely to have taken place prior to investor visit. Past village involvement in land conflicts may have negative implications for the upcoming relationship between the company and the villagers (i.e. granting lease rights for land, distrust in village) jeopardizing smooth business operations. Consequently, larger shares of formal village land could be attractive for private companies to avoid future conflict. Next, we expect a negative relationship between village wealth and investor visit. This is because poorer villages may have less alternative income-generating activities and their main asset is probably land, which provides investors with a good bargaining position. 
Our expectation regarding the impact of the explanatory variables on the incidence of contract adoption largely coincide with the impact on investor visit. Generally, the village-level factors that indicate that a village is located in a more rural area (i.e. smaller population, more village land, poorer accessibility, no access to electricity) are expected to be positively correlated with contract adoption. Next, since contract farming has the potential to improve livelihoods we expect that villages with a lower wealth index are more inclined to adopt a contract. Also because a lower wealth index possibly reflects fewer outside business options. Finally, in case the explanatory variables are insignificant, this would suggest that contract farming in the oil palm sector was inclusive, conditional on being visited by an investor.

\section{Modeling impacts on economic development}

\section{Village wealth index}

We analyze the effects of communal-company partnerships on economic development that we proxy by village wealth. Thus, we created a village wealth measure - wealth index (WI) - in following the idea of Sahn and Stifel (2003). Technically, WI is a function of various percentages of individual-level assets and is specified as follows:

$W I_{v}=\beta_{1}$ motorbike $_{v}+\beta_{2}$ car $_{v}+\beta_{3}$ truck $_{v}+\beta_{4}$ tv $_{v}+\beta_{5}$ dish $_{v}+\beta_{6}$ mobile $_{v}+$

$\beta_{7}$ fridge $_{v}+\beta_{8} \operatorname{aircon}_{v}+\beta_{9}$ computer $_{v}$,

where the $\beta \mathrm{s}$ are the generated results from a principle component analysis. The various wealth components are the percentage of households owning the following assets in village $v$ : motorbike, car, truck, television, satellite dish for television reception, mobile phone, fridge, air-conditioning, and generator. ${ }^{9}$ We normalized $W I$ resulting in an index with scores between 0 and 1 , where values closer to zero reflect lower relative asset

\footnotetext{
${ }^{9}$ As a robustness check, we constructed an alternative WI adding various variables distance to a health clinic and to an elementary school - to the specification.
} 
ownership. Moreover, since the variable is within the range of $0-1$, the estimation results can be interpreted as percentages.

\section{Modeling base effects}

We want to understand how economic development (i.e. WI) at the village level is influenced by communal-company partnerships. As discussed, the involvement in these partnership formations happens through contract farming schemes which are not only beneficial to the contract participants (direct effect) but also to other villagers who benefit from improved infrastructure (indirect effect). We specified the following equation:

$W I_{1 v t}=\alpha_{1}+\beta_{1} 2012_{v}+\delta_{1}$ contract $_{v t}+\rho_{1} X_{v t-10}+\varepsilon_{1 v}+\mu_{1 v t}$

where the $W I_{v t}$ is the relative wealth of village $v$ at time $t$, contract $_{v t}$ is a dummy variable that reflects if a contract was signed in village $v$ at time $t ; X_{v t-10}$ is a vector of village-controls in village $v$ at time $t$-10; the lagged values are used to avoid issues of endogeneity. $\varepsilon$ captures the time-invariant unobserved factors that affect the WI. To control for these unobserved heterogeneities we employ a fixed/random effects model depending on the results of the Hausman test. $\mu_{1 v t}$ is the idiosyncratic error term that changes over time and across villages. We also include the year dummy $2012_{v}$ to control for a possible time trend. Time $t$ includes the observations for 2002 and 2012 and, accordingly, $t$-10 includes the values for 1992 and 2002.

The vector of variables, $X_{v t-10}$, includes socioeconomic village-level factors. We control for population density. For Jambi, higher population densities are associated with more urban settlements, whereas lower population densities are more likely to be found in Jambi's rural areas. Generally it can be expected that villages in urban areas are richer compared with their rural counterparts. Consequently, we predict that population density has a positive effect on village wealth. 
Moreover, we control for institutional differences between the villages by including the share of households holding government land titles. Our expectation is mixed. There may be a positive relationship between land titles and village wealth, because land titles can be used to access formal credit. In turn, villages with lower shares of land titles may less frequently access formal credit and, consequently, cannot use this for accumulating wealth. However, the relationship may also be negative. For example, larger shares of land titles could lead to a decrease in village wealth because the money spent on applying for a land title cannot be used to purchase other assets.

Next, access to electricity is likely to induce economic development and thus we expect a positive correlation with village wealth. In a similar vein, we predict the distance to an all season road to be positively correlated with village wealth. Better village accessibility allows for more outside options which, in turn, fosters economic development. Furthermore, the distance to an oil palm mill may be an indicator for the degree of integration into the oil palm industry. This may have positive effects on village wealth, for instance, due to reduced transaction costs. Also likely, industry development may be accompanied with the emergence of new markets and various employment opportunities (e.g. oil palm mill, oil palm estate, transportation of oil palm fruits, security, input markets) which are likely to positively affect village wealth.

Moreover, oil palm smallholders without any contract have gained increasing importance in Jambi. These may, at least partly, have an effect on the accumulation of wealth at the village level. We control for the influence of independent oil palm farmers by including a variable which captures the share of oil palm land cropped by independent smallholders. Finally, contractual conflicts with private companies may have negative implications for economic development, for instance, because farmers stop working, and/or companies would refrain from disbursing salaries.

Furthermore, we will run two additional specifications of equation (7) in which we replace contract by contract size and contract length, respectively. The reasons are the following. The contract dummy captures the effect of being included in the oil palm 
industry for the entire village. However, we realize that there are large variations regarding the amount of villagers under contract. Therefore, we account for this by including contract size in an additional specification. We argue that contract size is positively correlated with WI because not only more villagers may benefit from contract farming but also other villagers may benefit more. For example, villages with larger shares of contract farmers may be more important for private companies than villages where only a few farmers are contracted. This may result in improved village infrastructure. In a third model specification of equation (7) we include the variable contract length. In doing so, we control for a time effect. It may be argued that villages where contracts were signed in the past (say 10 years ago) could exhibit a larger WI than villages that signed a contract in the more recent past (say 2 years ago). In a similar vein, the infrastructural improvements (e.g. roads, markets) need time to develop and thus to materialize their effect on WI. Therefore, the variable contract length captures the amount of years that passed since a contract was signed in a village. Technically, it takes the value 1 if the contract was signed in 2012, the value 2 if a contract was signed in 2011, etc., and 0 if no contract was signed. In addition, to examine if the contract effect is linear or diminishes over time we add the squared terms of contract length.

\section{Modeling phase effects}

As we discussed earlier, the oil palm development in Jambi has undergone several phases. It may be argued that village wealth is affected by the actual phase a contract was adopted in. To investigate this, we distinguish two major phases: the government-led phase and the market-oriented phase. Within the former phase the basis of every contract was the package as well as subsidized loans which were not guaranteed anymore in the subsequent market-oriented phase. In fact, decentralization shifted budgetary responsibilities to the district governments which, consequently, competed for attracting private company investments (McCarthy et al. 2012). In addition, this phase introduced more competition among private companies which may have led to a better bargaining position of the village. However, negotiations had to be in line with district - rather than 
central government - regulations, providing another opportunity for private companies to exploit their favorable position vis-à-vis district governments (idem). Moreover, villages that were involved in the oil palm industry in the government-led phase were more likely benefit from spillover effects induced by government infrastructural investments (Larson, 1996). Taken together, we predict that compared to contracts adopted in the marketoriented phase, contracts adopted in government-led phase had more potential to be beneficial for village communities.

To model this, we specified an alternative specification that is almost identical to equation (7). The difference is that we break down the contract variable to account for the respective phase of adoption. In doing so, we replace contract with two dummy variables: the first dummy captures the effect of contracts that were adopted in the government-led phase; the second dummy captures the contract effect for the marketoriented phase. The reference group consists of villages without a contract. Accordingly, we specified contract size. Overall, this allows us to control for some of the potential heterogeneity originating from the respective phase of adoption that may affect our outcome variable WI.

\subsection{Results and discussion}

\section{Descriptive statistics}

Throughout the period of interest, from 1992 until 2012, contracts had been adopted in our research region. Out of our total sample of villages that existed in $1992(\mathrm{~N}=78), 49$ were visited by an investor. Figure 5 depicts the year in which villages accepted $(\mathrm{N}=27)$ or rejected $(\mathrm{N}=22)$ a contract offer. It is striking that in the early 1990s relatively few offers were made which, in turn, were almost always accepted. Especially towards the end of our period of interest, however, villages were more frequently being visited and accepted the offers less often. Considering the process of liberalization associated with 
the earlier mentioned market-oriented phase, the increasing involvement of private companies in the oil palm sector is not surprising.

Whereas contractual opportunities increased, participation in contract farming schemes had overall been reduced throughout the entire period. In this regard, Figure 6 depicts the average share of households under contract in contract villages per year. The trend is clear: the number of households under contract is decreasing. Expressed in mean values, in 2002 about $43 \%$ of the farming households participated in contract farming, and $35 \%$ in 2012 (also see Table 5). Many smallholders have started to cultivate oil palm independently due to a decreasing need for company support for various reasons (i.e. better access to loans and inputs, acquired agronomic knowledge) (McCarthy, 2010). This is also reflected in our data. In 1992, only a small share of total oil palm land was cultivated independently (5\%). This is in stark contrast to the year 2012 where the average share of independently cultivated oil palm land increased to 74\% (Table 5).

Figure 5. Contracts rejected and accepted at village by year

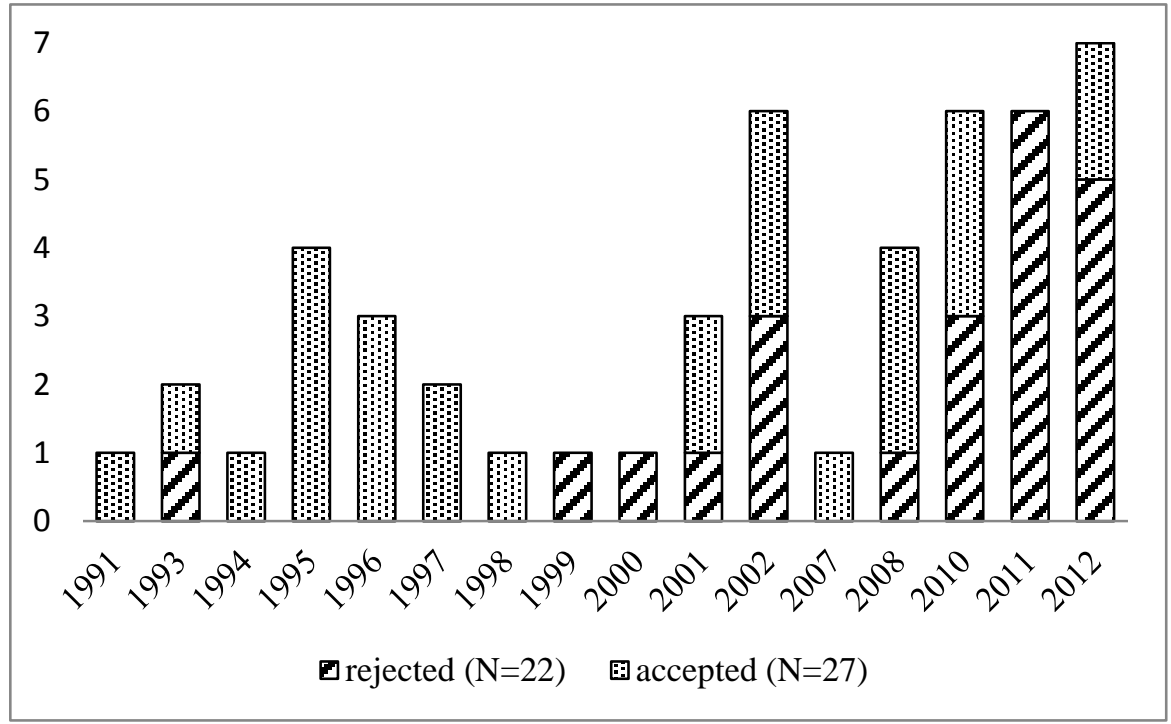


Figure 6. Average share of contract households per contract village by year

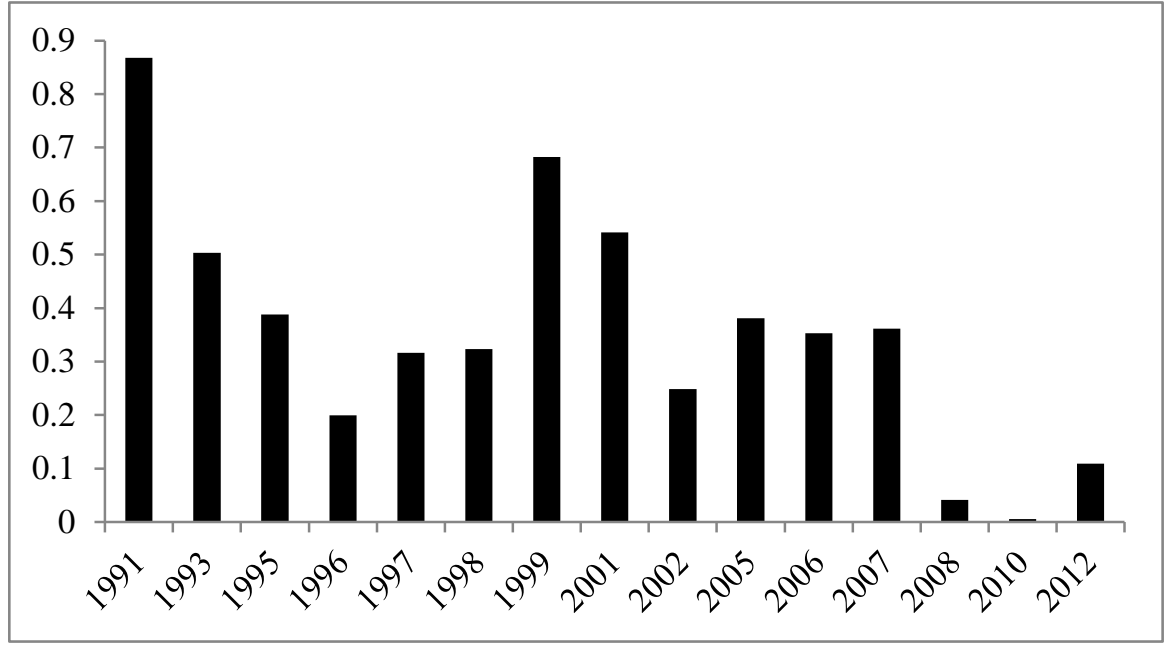

Table 5. Descriptive statistics I

\begin{tabular}{|c|c|c|c|}
\hline & \multicolumn{3}{|c|}{ Means (Std. dev.) } \\
\hline & 1992 & 2002 & 2012 \\
\hline & \multicolumn{3}{|c|}{ Full Sample $(\mathrm{N}=78)$} \\
\hline Wealth index & $\begin{array}{l}0.266 \\
(0.223)\end{array}$ & $\begin{array}{l}0.509 \\
(0.249)\end{array}$ & $\begin{array}{l}0.742 \\
(0.137)\end{array}$ \\
\hline Population density & $\begin{array}{l}0.466 \\
(0.558)\end{array}$ & $\begin{array}{l}0.753 \\
(0.813)\end{array}$ & $\begin{array}{l}1.021 \\
(1.097)\end{array}$ \\
\hline Distance to an all season road $(\mathrm{km})$ & $\begin{array}{l}4.438 \\
(14.07)\end{array}$ & $\begin{array}{l}2.639 \\
(7.831)\end{array}$ & $\begin{array}{l}1.152 \\
(5.711)\end{array}$ \\
\hline Distance to oil palm mill $(\mathrm{km})$ & $\begin{array}{l}61.44 \\
(61.24)\end{array}$ & $\begin{array}{l}45.39 \\
(50.87)\end{array}$ & $\begin{array}{l}30.63 \\
(24.64)\end{array}$ \\
\hline Electricity (d) & $\begin{array}{l}0.374 \\
(0.477)\end{array}$ & $\begin{array}{l}0.756 \\
(0.432)\end{array}$ & $\begin{array}{l}0.910 \\
(0.287)\end{array}$ \\
\hline Government land title (share of $\mathrm{HH}$ ) & $\begin{array}{l}0.201 \\
(0.346)\end{array}$ & $\begin{array}{l}0.335 \\
(0.389)\end{array}$ & $\begin{array}{l}0.466 \\
(0.351)\end{array}$ \\
\hline $\begin{array}{l}\text { Share of oil palm land under } \\
\text { independent cultivation }\end{array}$ & $\begin{array}{l}0.051 \\
(0.163)\end{array}$ & $\begin{array}{l}0.178 \\
(0.304)\end{array}$ & $\begin{array}{l}0.738 \\
(0.368)\end{array}$ \\
\hline \multicolumn{4}{|c|}{ Contract village sample (i.e. if contract exists in village) } \\
\hline & $\mathrm{N}=1$ & $\mathrm{~N}=17$ & $\mathrm{~N}=27$ \\
\hline Contract size & $\begin{array}{l}0.868 \\
\text { (.) }\end{array}$ & $\begin{array}{l}0.434 \\
(0.341)\end{array}$ & $\begin{array}{l}0.353 \\
(0.322)\end{array}$ \\
\hline Contract length (d) & $\begin{array}{l}-1 \\
(.)\end{array}$ & $\begin{array}{l}6.765 \\
(2.704)\end{array}$ & $\begin{array}{l}12.41 \\
(6.351)\end{array}$ \\
\hline Contractual conflict (d) & $\begin{array}{l}0 \\
(0)\end{array}$ & $\begin{array}{l}0.235 \\
(0.437)\end{array}$ & $\begin{array}{l}0.185 \\
(0.396)\end{array}$ \\
\hline
\end{tabular}


Next, in 2012 the average contract length was about 12.4 years (Table 5). The shortest contract length is 1 year and the longest contract lasted for 22 years suggesting that the most recent contract was adopted in 2012 and the longest lasting contract in $1991{ }^{10}$ It is also worth mentioning that none of the contracts ended during the period of interest. Finally, we observe some incidences of conflicts with a private company. These are mainly related to not well-understanding contract conditions and the alteration of conditions from the company side after the contract was agreed upon and signed. These issues have also been found to be major causes of conflict in other studies (Sirait, 2009; Rist et al., 2010). Despite the increase of signed contracts from 1992 - 2012, we observe that contractual conflicts exclusively occurred between 1992 and 2002.

Table 5 and 6 summarize the descriptive statistics for our explanatory variables. Here, we want to highlight the WI variable. In 1992, the average village had a wealth score of 0.27 . Ten years later, the average village could almost double this score. Finally, in 2012 this score reached the value 0.74. Although villages have become richer over the years, when they were first met by an investor, wealth was equally distributed across the sample villages (Table 6). In this respect, we do not find a significant difference between villages which were visited by an investor (0.36) and those which were not (0.34). Next, conditional on being visited, prior to contract adoption villages seem to have a significantly lower WI (0.32) compared to villages which rejected a contract offer $(0.41)$. Less outside options (e.g. less employment opportunities) for villages before adopting a contract may be the reason.

Comparing the remaining village characteristics of villages that were visited by an investor to those villages that were not, it seems that villages were fairly similar in terms of population, land area, distance to an all season road, access to electricity and village type (Table 6 column 2-3). The two groups of villages also differ in certain aspects. For

\footnotetext{
${ }^{10}$ Generally, we explain contract adoption with village characteristics from the year 1992. It may be argued that we run into problems of endogeneity when we use data for 1992 to explain contract adoption in 1991. However, we believe that village characteristics do not alter considerably within one year. Thus, we argue that the biases are likely to be minimal. Moreover, this is only the case for one observation.
} 
example, investor villages were characterized by significantly steeper average land slopes and a location closer to an oil palm mill. In addition, investor villages also possessed on average more government land titles prior to being visited. This may point at a companies' strategy to avoid areas with ongoing or the potential of land conflicts.

\section{Table 6. Descriptive statistics II}

\begin{tabular}{|c|c|c|c|c|c|}
\hline & \multicolumn{5}{|c|}{ Means (Std. dev.) } \\
\hline & $\begin{array}{c}\text { Full } \\
\text { sample } \\
(\mathrm{N}=78)\end{array}$ & $\begin{array}{c}\text { Investor } \\
\text { visit } \\
(\mathrm{N}=49)\end{array}$ & $\begin{array}{c}\text { No } \\
\text { investor } \\
\text { visit } \\
(\mathrm{N}=29)\end{array}$ & $\begin{array}{c}\text { Contract } \\
\text { adoption } \\
(\mathrm{N}=27)\end{array}$ & $\begin{array}{c}\text { No } \\
\text { contract } \\
\text { adoption } \\
(\mathrm{N}=22)\end{array}$ \\
\hline & (1) & (2) & (3) & (4) & (5) \\
\hline Village population & $\begin{array}{l}1217 \\
(750.4)\end{array}$ & $\begin{array}{l}1466 \\
(884.4)\end{array}$ & $\begin{array}{l}1427 \\
(785.6)\end{array}$ & $\begin{array}{l}1472 \\
(890.1)\end{array}$ & $\begin{array}{l}1457 \\
(898.1)\end{array}$ \\
\hline Village land (ha) & $\begin{array}{l}6614 \\
(11482)\end{array}$ & $\begin{array}{l}6854 \\
(9484)\end{array}$ & $\begin{array}{l}6206 \\
(14425)\end{array}$ & $\begin{array}{l}6469 \\
(6831)\end{array}$ & $\begin{array}{l}7326 \\
(12140)\end{array}$ \\
\hline Population density & $\begin{array}{l}0.526 \\
(0.619)\end{array}$ & $\begin{array}{l}0.521 \\
(0.705)\end{array}$ & $\begin{array}{l}0.535 \\
(0.451)\end{array}$ & $\begin{array}{l}0.523 \\
(0.727)\end{array}$ & $\begin{array}{l}0.516 \\
(0.693)\end{array}$ \\
\hline Average land slope & $\begin{array}{l}1.934 \\
(0.862)\end{array}$ & $\begin{array}{l}2.116 * * * \\
(0.881)\end{array}$ & $\begin{array}{l}1.628 \\
(0.746)\end{array}$ & $\begin{array}{l}2.252 \\
(0.997)\end{array}$ & $\begin{array}{l}1.949 \\
(0.701)\end{array}$ \\
\hline Distance to an all season road $(\mathrm{km})$ & $\begin{array}{l}4.438 \\
(14.06)\end{array}$ & $\begin{array}{l}3.735 \\
(11.65)\end{array}$ & $\begin{array}{l}2.061 \\
(6.154)\end{array}$ & $\begin{array}{l}3.931 \\
(12.675)\end{array}$ & $\begin{array}{l}3.493 \\
(10.555)\end{array}$ \\
\hline Distance to oil palm mill $(\mathrm{km})$ & $\begin{array}{l}61.44 \\
(61.24)\end{array}$ & $\begin{array}{l}49.75^{*} \\
(60.34)\end{array}$ & $\begin{array}{l}71.36 \\
(60.46)\end{array}$ & $\begin{array}{l}52.55 \\
(72.66)\end{array}$ & $\begin{array}{l}46.32 \\
(41.99)\end{array}$ \\
\hline Electricity (d) & $\begin{array}{l}0.374 \\
(0.477)\end{array}$ & $\begin{array}{l}0.535 \\
(0.492)\end{array}$ & $\begin{array}{l}0.621 \\
(0.494)\end{array}$ & $\begin{array}{l}0.415 \\
(0.479)\end{array}$ & $\begin{array}{l}0.682 \\
(0.477)\end{array}$ \\
\hline Wealth index & $\begin{array}{l}0.355 \\
(0.241)\end{array}$ & $\begin{array}{l}0.363 \\
(0.231)\end{array}$ & $\begin{array}{l}0.342 \\
(0.261)\end{array}$ & $\begin{array}{l}0.321 * \\
(0.224)\end{array}$ & $\begin{array}{l}0.415 \\
(0.235)\end{array}$ \\
\hline Government land title (share of $\mathrm{HH}$ ) & $\begin{array}{l}0.201 \\
(0.346)\end{array}$ & $\begin{array}{l}0.283 * * \\
(0.378)\end{array}$ & $\begin{array}{l}0.141 \\
(0.288)\end{array}$ & $\begin{array}{l}0.283 \\
(0.388)\end{array}$ & $\begin{array}{l}0.283 \\
(0.375)\end{array}$ \\
\hline Transmigrant village (d) & $\begin{array}{l}0.154 \\
(0.363)\end{array}$ & $\begin{array}{l}0.184 \\
(0.391)\end{array}$ & $\begin{array}{l}0.103 \\
(0.309)\end{array}$ & $\begin{array}{l}0.259 * \\
(0.446)\end{array}$ & $\begin{array}{l}0.091 \\
(0.294)\end{array}$ \\
\hline
\end{tabular}

Notes: Means are based on data for the years 1992 and 2002, depending on the year of investor visit/contract adoption. If investor visit/contract adoption occurred between 1992-2001, we used the data for the year 1992; likewise, if investor visit/contract adoption occurred between 2002-2012, we used the data for the year 2002; the asterisks refer to the significance levels from a simple t-test between the groups (2)-(3) and (4)-(5), respectively; *** significance at the $1 \%$ level; ** significance at the $5 \%$ level; * significance at the $10 \%$ level. 
Comparing village characteristics of villages prior to contract adoption with villages which rejected a contract offer (column 4-5), we only find little significant differences. Yet, contract villages consist significantly more of villages founded by the governmentled relocation program (26\%), named the transmigrasi program. This is not surprising because all of the villages received a contract per definition. That there are transmigration villages which rejected the contract offer (9\%) can be explained by the fact that a few transmigration villages received a contract in the 1980s and were approached by an investor after their first contract expired. It is worth mentioning that only one transmigrant village accepted a contract for the second time after the first one expired. We will now turn to the estimation results explaining contract adoption and impacts of contract farming on village wealth.

\section{Estimation results investor visit and contract adoption}

We model contract adoption in two steps because of its conditionality on investor visit. We employ a bivariate probit with selection model to deal with a possible selection bias (see Table A4 in the Appendix). The model is identified by using the average land slope as an instrument. The correlation in the errors equals -0.28 which is insignificant according to the Wald test. Consequently, our estimation results are unlikely to suffer from a selection bias. Thus, in Table 7 we present the univariate probit estimation results which generally confirm the estimation results of the bivariate probit with sample selection.

Staying with the probit results in Table 7 , the estimation results reveal that investors are more likely to visit villages with steeper average land slopes (equation 4). As we have argued, before the Indonesian government structurally focused on developing an oil palm sector in the early 1990s, the emphasis was on the rubber sector. The well-establishment of rubber in Jambi has led to a scarcity of land. As a consequence, available land was found in areas with, on average, steeper land slopes. 
Next, the results suggest that villages that are located in proximity to an existing oil palm industry (i.e. oil palm mill) are more likely to be targeted by an investor. Specifically, every additional kilometer of distance from the village to the closest oil palm mill decreases the probability of being visited by an investor by $0.2 \%$. This is not surprising because proximity to existing oil palm industry reduces transaction costs. In addition, a good connection to oil palm mills is needed to guarantee that the FFB are processed in a timely manner. Usually, when the fruits are harvested they start to perish rapidly after 48 hours.

Government land titles significantly predict investor visit. It appears that private companies are more attracted by villages with higher shares of secured land, rather than unsecured land that is largely governed by customary land rights. This is likely a response to the presence of many unresolved land conflicts between communities and companies which often resulted in physical opposition (Colchester et al., 2006) that, at the same time, disrupted smooth business operations. Overall, this result stresses the importance of formal land titles, not only for borrowing formal credit, but also to increase the villages' attractiveness.

Other factors, such as proximity to all season road and availability of electricity, we expected to be conducive to company operations, are not significant.

We now turn to the discussion of the factors that affect the probability of contract adoption. Conditional on investor visit, we find that only one variable is significant. Villages without access to electricity have a 35\% higher probability of adoption a contract. As predicted, no access to the public grid could be an indication for being located in rural areas where economic opportunities are often scant. Thus, a contract represents a welcome opportunity to stimulate economic development and thus, village wealth. Apart from this, none of the explanatory variables enter significantly in explaining contract adoption. 
Finally, as a robustness check we reduced the explanatory variables in the model and find consistent results. We now turn to the results regarding the impact of contract adoption on village wealth.

Table 7. Probit estimation results for determinants of investor visit and contract adoption

\begin{tabular}{|c|c|c|c|c|}
\hline & $\begin{array}{c}\text { Investor } \\
\text { visit } \\
\mathrm{N}=78\end{array}$ & $\begin{array}{c}\text { Contract } \\
\text { adoption } \\
\mathrm{N}=49\end{array}$ & $\begin{array}{c}\text { Investor } \\
\text { visit } \\
\mathrm{N}=78\end{array}$ & $\begin{array}{c}\text { Contract } \\
\text { adoption } \\
\mathrm{N}=49\end{array}$ \\
\hline & \multicolumn{2}{|c|}{ Coefficient } & \multicolumn{2}{|c|}{ Marginal effects } \\
\hline & (1) & (2) & (3) & (4) \\
\hline Average land slope & $\begin{array}{l}0.633 * * * \\
(0.248)\end{array}$ & & $\begin{array}{l}0.234 * * * \\
(0.088)\end{array}$ & \\
\hline Village land area (ha; $x 1000)$ & $\begin{array}{l}-0.002 \\
(0.018)\end{array}$ & $\begin{array}{l}-0.028 \\
(0.025)\end{array}$ & $\begin{array}{l}-0.001 \\
(0.001)\end{array}$ & $\begin{array}{l}-0.011 \\
(0.011)\end{array}$ \\
\hline Village population $(\mathrm{x} 1000)$ & $\begin{array}{l}-0.024 \\
(0.206)\end{array}$ & $\begin{array}{l}0.406 \\
(0.274)\end{array}$ & $\begin{array}{l}-0.009 \\
(0.081)\end{array}$ & $\begin{array}{l}0.161 \\
(0.111)\end{array}$ \\
\hline Electricity (d) & $\begin{array}{l}-0.181 \\
(0.382)\end{array}$ & $\begin{array}{c}-0.887 * \\
(0.509)\end{array}$ & $\begin{array}{l}-0.067 \\
(0.141)\end{array}$ & $\begin{array}{l}-0.349 * \\
(0.201)\end{array}$ \\
\hline Distance to all season road $(\mathrm{km})$ & $\begin{array}{l}0.004 \\
(0.013)\end{array}$ & $\begin{array}{l}-0.009 \\
(0.017)\end{array}$ & $\begin{array}{l}0.002 \\
(0.001)\end{array}$ & $\begin{array}{l}-0.003 \\
(0.011)\end{array}$ \\
\hline Distance to oil palm mill $(\mathrm{km})$ & $\begin{array}{l}-0.005^{*} \\
(0.003)\end{array}$ & $\begin{array}{l}0.000 \\
(0.002)\end{array}$ & $\begin{array}{l}-0.002 * \\
(0.001)\end{array}$ & $\begin{array}{l}-0.000 \\
(0.000)\end{array}$ \\
\hline Wealth index & $\begin{array}{l}0.204 \\
(0.795)\end{array}$ & $\begin{array}{l}-0.798 \\
(1.114)\end{array}$ & $\begin{array}{l}0.075 \\
(0.029)\end{array}$ & $\begin{array}{l}-0.315 \\
(0.438)\end{array}$ \\
\hline Transmigrant village (d) & $\begin{array}{l}0.296 \\
(0.436)\end{array}$ & $\begin{array}{l}0.611 \\
(0.512)\end{array}$ & $\begin{array}{l}0.104 \\
(0.146)\end{array}$ & $\begin{array}{l}0.227 \\
(0.172)\end{array}$ \\
\hline Government land titles (share of $\mathrm{HH}$ ) & $\begin{array}{l}1.454 * * * \\
(0.587)\end{array}$ & $\begin{array}{l}-0.289 \\
(0.501)\end{array}$ & $\begin{array}{l}0.538 * * * \\
(0.212)\end{array}$ & $\begin{array}{l}-0.114 \\
(0.197)\end{array}$ \\
\hline Constant & $\begin{array}{l}-0.854 \\
(0.618) \\
\end{array}$ & $\begin{array}{l}0.512 \\
(0.564)\end{array}$ & & \\
\hline Log likelihood & -42.19 & -29.64 & & \\
\hline Wald $\operatorname{chi}^{2}(9 / 8)$ & 15.65 & 8.00 & & \\
\hline Prob. $>$ chi $^{2}$ & 0.07 & 0.43 & & \\
\hline Pseudo $\mathrm{R}^{2}$ & 0.18 & 0.12 & & \\
\hline
\end{tabular}

Notes: Explanatory variables are based on data for the years 1992 and 2002, depending on the year of investor visit/contract adoption. If investor visit/contract adoption occurred between 1992-2001, we used the data for the year 1992; likewise, if investor visit/contract adoption occurred between 2002-2012, we used the data for the year $2002 ; * * *$ significance at the $1 \%$ level; ** significance at the $5 \%$ level; * significance at the $10 \%$ level; robust standard errors in parentheses. 


\section{Impact of oil palm contracts}

\section{Base regression results}

The regression results are depicted in Table 8 . In all regression we use a fixed effects model, as the Hausman test largely suggests.

First, we find that village wealth had increased for all villages: compared to 2002, in 2012 the WI was around 22 percentage points higher. However, the mere adoption of a contract does not seem to significantly affect village wealth (column 1). Controlling for confounding factors, contract adoption becomes positively significant at the $10 \%$ level (column 2). Jointly, it seems that the mere presence of a contract only reveals a weakly significant effect on village wealth. Rather than contract adoption per se, it may be that the share of farmers under contract is pivotal for promoting the accumulation of village wealth. Indeed, contract size has a positive effect on village wealth (column 3) which remains significant after inserting control variables to the regression (column 4). In more detail, an increase of additional $10 \%$ of farmers under contract leads to a $7.3 \%$ increase in village wealth.

Further, we argued that after a contract is adopted the materialization of wealth takes time. In different words, we predicted that village wealth increases in the years that have passed since the contract was signed. Indeed, one additional year of contract duration increases WI by about 4.4 percentage points (column 5). In addition, the effect appears to be non-linear: the squared term enters negatively significant which suggests that the positive effects associated with contract length diminish over time. These findings are robust to the effects of confounding factors (column 6).

Regarding the explanatory variables, apart from distance to an all season road and contractual conflict, the remaining variables are not significant in the overall regression estimations. We find that increasing village accessibility is positively associated with village wealth. As we predicted, better village accessibility increases the access to 
outside options and, thus, to participate in alternative income-generating activities (i.e. in neighboring cities, markets, etc.).

Table 8. Panel estimation results for contract adoption, contract size and contract length

\begin{tabular}{|c|c|c|c|c|c|c|}
\hline & \multicolumn{6}{|c|}{ Dependent variable: wealth index } \\
\hline & \multicolumn{6}{|c|}{ Coefficient (Standard error) } \\
\hline & $(1)$ & $(2)$ & (3) & (4) & $(5)$ & (6) \\
\hline \multirow[t]{2}{*}{ Year 2012 (d) } & $0.216 * * *$ & $0.223^{* * *}$ & $0.215^{* * *}$ & $0.230 * * *$ & $0.202 * * *$ & $0.199 * * *$ \\
\hline & $(0.025)$ & $(0.047)$ & $(0.024)$ & $(0.043)$ & $(0.028)$ & $(0.047)$ \\
\hline \multirow[t]{2}{*}{ Contract (d) } & 0.129 & $0.154 *$ & & & & \\
\hline & $(0.089)$ & $(0.086)$ & & & & \\
\hline \multirow[t]{2}{*}{ Contract size } & & & $0.628 * *$ & $0.729 * * *$ & & \\
\hline & & & $(0.277)$ & $(0.224)$ & & \\
\hline \multirow[t]{2}{*}{ Contract length (years) } & & & & & $0.044 * *$ & $0.048 * * *$ \\
\hline & & & & & $(0.018)$ & $(0.017)$ \\
\hline \multirow[t]{2}{*}{ Contract length squared (years) } & & & & & $-0.002 * *$ & $-0.002 * *$ \\
\hline & & & & & $(0.001)$ & $(0.001)$ \\
\hline \multirow{2}{*}{$\begin{array}{l}\text { Share of oil palm land under } \\
\text { independent cultivation }_{\mathrm{t}-10}\end{array}$} & & 0.074 & & 0.084 & & 0.119 \\
\hline & & $(0.103)$ & & $(0.106)$ & & $(0.111)$ \\
\hline \multirow[t]{2}{*}{ Distance to oil palm mill $\mathrm{t}_{-10}(\mathrm{~km})$} & & 0.000 & & 0.000 & & 0.000 \\
\hline & & $(0.000)$ & & $(0.000)$ & & $(0.000)$ \\
\hline \multirow[t]{2}{*}{ Distance to all season $\operatorname{road}_{\mathrm{t}-10}(\mathrm{~km})$} & & $-0.005^{*}$ & & $-0.005^{*}$ & & -0.003 \\
\hline & & $(0.003)$ & & $(0.003)$ & & $(0.002)$ \\
\hline \multirow[t]{2}{*}{ Population density $\mathrm{t}_{\mathrm{t}-10}$} & & -0.017 & & -0.028 & & -0.032 \\
\hline & & $(0.082)$ & & $(0.081)$ & & $(0.081)$ \\
\hline \multirow[t]{2}{*}{ Electricity $_{\mathrm{t}-10}(\mathrm{~d})$} & & -0.031 & & -0.043 & & -0.025 \\
\hline & & $(0.047)$ & & $(0.046)$ & & $(0.048)$ \\
\hline \multirow[t]{2}{*}{ Government land titles $_{\mathrm{t}-10}$} & & 0.041 & & 0.049 & & 0.075 \\
\hline & & $(0.085)$ & & $(0.082)$ & & $(0.086)$ \\
\hline \multirow[t]{2}{*}{ Contractual conflict ${ }_{\mathrm{t}-10}(\mathrm{~d})$} & & -0.082 & & -0.103 & & $-0.142 *$ \\
\hline & & $(0.056)$ & & $(0.067)$ & & $(0.087)$ \\
\hline \multirow[t]{2}{*}{ Constant } & $0.481 * * *$ & $0.457 * * *$ & $0.449 * * *$ & $0.431 * * *$ & $0.464 * * *$ & $0.436^{* * *}$ \\
\hline & $(0.025)$ & $(0.073)$ & $(0.030)$ & $(0.074)$ & $(0.024)$ & $(0.073)$ \\
\hline Observations & 156 & 156 & 156 & 156 & 156 & 156 \\
\hline $\mathrm{R}^{2}$ (overall) & 0.19 & 0.22 & 0.07 & 0.08 & 0.16 & 0.17 \\
\hline Hausman & 3.55 & $14.28 * *$ & $9.27 * * *$ & $31.84 * * *$ & $20.61 * * *$ & $53.72 * * *$ \\
\hline Model specification & FE & $\mathrm{FE}$ & FE & FE & FE & FE \\
\hline
\end{tabular}

Notes: *** significance at the $1 \%$ level; ** significance at the $5 \%$ level; $*$ significance at the $10 \%$ level; standard errors clustered at the village level in parentheses. 
Table 9. Panel estimation results for contract adoption, contract size by adoption phase

\begin{tabular}{|c|c|c|c|c|}
\hline & \multicolumn{4}{|c|}{$\begin{array}{l}\text { Dependent variable: wealth index } \\
\text { Coefficient (Standard error) }\end{array}$} \\
\hline & (1) & (2) & (3) & (4) \\
\hline Year $2012(d)$ & $\begin{array}{l}0.225 * * * \\
(0.046)\end{array}$ & $\begin{array}{l}0.206^{* * *} \\
(0.047)\end{array}$ & $\begin{array}{l}0.226 * * * \\
(0.043)\end{array}$ & $\begin{array}{l}0.209 * * * \\
(0.045)\end{array}$ \\
\hline Government-led contract (1991-1998) (d) & $\begin{array}{l}0.444 * * * \\
(0.083)\end{array}$ & $\begin{array}{l}0.437 * * * \\
(0.085)\end{array}$ & & \\
\hline Market-oriented contract (1999-2012) (d) & $\begin{array}{l}0.121 \\
(0.089)\end{array}$ & $\begin{array}{l}0.091 \\
(0.088)\end{array}$ & & \\
\hline Government-led contract size (1991-1998) & & & $\begin{array}{l}3.737 * * * \\
(0.714)\end{array}$ & $\begin{array}{l}3.689 * * * \\
(0.728)\end{array}$ \\
\hline Market-oriented contract size (1999-2012) & & & $\begin{array}{l}0.686^{* * *} \\
(0.232)\end{array}$ & $\begin{array}{l}0.623 * * * \\
(0.237)\end{array}$ \\
\hline Contract length (years) & & $\begin{array}{l}0.011 \\
(0.008)\end{array}$ & & $\begin{array}{l}0.008 \\
(0.008)\end{array}$ \\
\hline $\begin{array}{l}\text { Share of oil palm land under independent } \\
\text { cultivation } \\
\text { t-10 }\end{array}$ & $\begin{array}{l}0.031 \\
(0.103)\end{array}$ & $\begin{array}{l}0.056 \\
(0.107)\end{array}$ & $\begin{array}{l}0.039 \\
(0.103)\end{array}$ & $\begin{array}{l}0.061 \\
(0.107)\end{array}$ \\
\hline Distance to oil palm mill $\mathrm{t}_{\mathrm{t}-10}(\mathrm{~km})$ & $\begin{array}{l}0.000 \\
(0.000)\end{array}$ & $\begin{array}{l}0.000 \\
(0.000)\end{array}$ & $\begin{array}{l}0.000 \\
(0.000)\end{array}$ & $\begin{array}{l}0.000 \\
(0.000)\end{array}$ \\
\hline Distance to all season $\operatorname{road}_{\mathrm{t}-10}(\mathrm{~km})$ & $\begin{array}{l}-0.004 * \\
(0.003)\end{array}$ & $\begin{array}{l}-0.004 * \\
(0.002)\end{array}$ & $\begin{array}{l}-0.005^{*} \\
(0.003)\end{array}$ & $\begin{array}{l}-0.004 * \\
(0.002)\end{array}$ \\
\hline Population density $\mathrm{t}_{\mathrm{t}-10}$ & $\begin{array}{l}-0.002 \\
(0.084)\end{array}$ & $\begin{array}{l}-0.027 \\
(0.084)\end{array}$ & $\begin{array}{l}-0.008 \\
(0.083)\end{array}$ & $\begin{array}{l}-0.026 \\
(0.082)\end{array}$ \\
\hline Electricity $_{\mathrm{t}-10}(\mathrm{~d})$ & $\begin{array}{l}-0.022 \\
(0.048)\end{array}$ & $\begin{array}{l}-0.011 \\
(0.049)\end{array}$ & $\begin{array}{l}-0.033 \\
(0.046)\end{array}$ & $\begin{array}{l}-0.022 \\
(0.048)\end{array}$ \\
\hline Government land titles $\mathrm{s}_{\mathrm{t}-10}$ & $\begin{array}{l}0.033 \\
(0.085)\end{array}$ & $\begin{array}{l}0.014 \\
(0.085)\end{array}$ & $\begin{array}{l}0.045 \\
(0.082)\end{array}$ & $\begin{array}{l}0.031 \\
(0.082)\end{array}$ \\
\hline Contractual conflict $t_{\mathrm{t}-10}(\mathrm{~d})$ & $\begin{array}{l}-0.076 \\
(0.051)\end{array}$ & $\begin{array}{l}-0.152 * \\
(0.081)\end{array}$ & $\begin{array}{l}-0.097 \\
(0.062)\end{array}$ & $\begin{array}{l}-0.154 * \\
(0.082)\end{array}$ \\
\hline Constant & $\begin{array}{l}0.389 * * * \\
(0.082)\end{array}$ & $\begin{array}{l}0.386^{* * * *} \\
(0.085)\end{array}$ & $\begin{array}{l}0.179 \\
(0.114)\end{array}$ & $\begin{array}{l}0.179 \\
(0.116)\end{array}$ \\
\hline Observations & 156 & 156 & 156 & 156 \\
\hline $\mathrm{R}^{2}$ (overall) & 0.13 & 0.10 & 0.01 & 0.01 \\
\hline Hausman & $18.45^{* *}$ & $46.18 * * *$ & $48.07 * * *$ & $37.50 * * *$ \\
\hline Model specification & FE & $\mathrm{FE}$ & $\mathrm{FE}$ & $\mathrm{FE}$ \\
\hline
\end{tabular}

Notes: $* * *$ significance at the $1 \%$ level; $* *$ significance at the $5 \%$ level; * significance at the $10 \%$ level; standard errors clustered at the village level in parentheses. 
Finally, contractual conflict affects wealth negatively (column 6). Since, it only enters significantly in one regression specification we should not overestimate this finding. Another interesting finding is that the share of oil palm land cultivated by independent smallholders is insignificant. However, this result should not be over-interpreted considering the use of lagged values. Compared to 2012, in the past independent smallholders were relatively few. We now examine if the actual phase of contract adoption matters for explaining WI.

\section{Results on government-led versus market-oriented contracts}

The results depicted in Table 9 reveal that contracts adopted before 1999, within the government-led phase, have an overall positive effect on village wealth (column 1). Compared to villages without a contract, these villages have had increased village wealth by $45 \%$. In contrast, villages that adopted a contract after 1998 within the marketoriented phase are not significantly different from villages without a contract. Rather than using the contract dummy, contract size enters positive and significant in both phases, compared to villages without a contract (column 3). In more detail, an additional $10 \%$ increase of farmers under contract in the government-led phase leads to an increase in village wealth by about 37 percentage points. In contrast, an increase of $10 \%$ of farmers under contract within the market-oriented phase would lead to a relatively small $7 \%$ increase in village wealth. Moreover, we control for contract length (column 2 and 4). The insignificance of this variable allows us to argue that the respective phase of adoption (i.e. government-led, market-oriented), rather than the duration of the contract, matters for explaining village wealth. In terms of the size of the effect the estimation results suggest that, compared to contracts adopted within the market-oriented phase, government-led contracts reveal larger positive effects on village wealth.

In sum, as predicted, compared to the market-oriented phase, the government-led phase is more associated with village wealth. Nevertheless, also the market-oriented phase, 
associated with liberalization and more bargaining power for village communities, stimulated the accumulation of village wealth, however, to a relatively lesser degree.

\subsection{Conclusion}

In this chapter, we investigated the effects of community-company partnerships within the Indonesian oil palm sector on economic development at the village level. In addition, we examined the conditions under which partnership formations (i.e. contract farming) are established. We use data from a survey conducted in randomly selected villages where we collected recall data through structured interviews with village leaders covering a period of 20 years, from 1992-2012.

The results suggest considerable positive economic benefits for villages within partnership formations with private companies. In particular, the share of farmers under contract appears to play a decisive role in inducing the accumulation of village wealth. Moreover, contract length is relevant as well. In this regard, villages that are involved in contract arrangements for many years tend to have larger village wealth levels, compared to villages where a contract has been established more recently. These positive effects associated with contract length, however, are not continuously increasing. At some point, the positive effects diminish.

Furthermore, throughout the 20 year period of analysis contracts were established. The results suggest that contracts adopted in the government-led phase (before 1999) were more beneficial for improving village wealth than contracts that were adopted in the market-oriented phase (after 1999). We conjecture that these differences are due to contractual arrangements (i.e. oil palm service 'package', subsidized loans), government control and infrastructural investments that were more pronounced in the government-led phase. However, due to the complexity and various combinations of contract conditions, in this study we are unable to distinguish between the effects of these features. This will be an interesting avenue for future research. 
Regarding the inclusion into the oil palm industry, the data show that the availability of land, proximity to an oil palm mill and secured land are the factors predicting that villages were targeted by private companies. Regarding the first, Jambi province is characterized by large areas which were already under rubber cultivation before oil palm was introduced. Increasingly, the availability of land shifted towards the remoter and more rural areas, where currently most of Jambi's oil palm plantations are located. Second, rather than good village accessibility, proximity to existing oil palm industry (i.e. processing mill) is crucial for being targeted. This allows private companies to reduce their transaction costs. Third, the data suggest that increasing shares of farmers possessing formal land titles attracts private companies to the village. We conjecture that this is a result of increasing conflicts that arose due to unclear land rights and are likely to have negative effects for smooth business operations. In addition, this supports the relevance of secured land for the possible inclusion into community-company partnerships.

Conditional on the factors that determine that an investor visits a village, we could demonstrate that no access to electricity predicts contract adoption at the village level. In different words, villages that are likely to be located in remoter areas because of their disconnection to the publicly provided grid seem to have few options to make an income; thus, these are more prone to adopt a contract. Overall, it appears that contract farming schemes have not been entirely equally accessible to all villages alike; however, we do not find evidence that the rural poor were excluded.

From the results we can draw some policy recommendations. First of all, the analysis demonstrates the importance of formal land titles for attracting private companies to the village. An increasing governmental effort is required to make land titling more accessible and the titling process more affordable for rural farmers. Second, we show the relevance of improved infrastructure for village wealth. Further investments are needed to continue this positive development. 
We realize that this research has some limitations. For example, we adopt a specific wealth measure to capture economic development. However, apart from an asset-based measure, economic development certainly has different aspects that we did not address. Future research could apply alternative and more durable wealth measures. For instance, the average income/consumption per capita could be used. Regarding a more durable measure, future research could adopt a wealth measure that captures the investment into expanding agricultural activities (i.e. share of households buying land in and outside their village). Further analysis is desirable that confirms the positive effects of contract farming for rural communities and expands the analysis for rural households. At the same time, the household-level analysis allows to investigate if contract farming has excluded certain farmers and if it has contributed to unequal economic developments within villages.

Finally, despite the overall positive effects of community-company partnerships, contract farming should not be perceived as a panacea for improving rural livelihoods in Indonesia or elsewhere. In contrast, we observe that there are other means as well. For instance, Jambi province is characterized by rubber farmers and, more recently, a surge of independent oil palm smallholders. However, since oil palm cultivation requires resources and knowledge, contract farming provides a means to stimulate the development of an oil palm sector in its infant stages. The importance of contract farming in the oil palm industry in Jambi is likely to decrease. It should be acknowledged that the sector has been undergoing a structural change from vertically integrated plantations towards increasingly independent production of oil palm; a transformation which is similar to the tea sector in Sri Lanka (Herath and Weersink, 2009). However, there are other parts of Indonesia (and globally), i.e. Kalimantan, Borneo, where the oil palm boom is yet to start. 


\title{
Chapter 4
}

\section{Market Integration and Institutional Change}

\begin{abstract}
A growing strand of literature investigates the links between formal and informal institutions and their effects on development. Yet, empirical research related to this topic is scarce. In this chapter, we analyze the effects of market integration into the oil palm sector on generalized trust at the village level. To do so, we elicit generalized trust through a behavioral experiment. Our data suggest that villages that are vertically integrated in the oil palm sector exhibit higher aggregated trust levels. Furthermore, we find long-term effects of market integration. The number of years villages are integrated in markets is positively associated with increased generalized trust. Analysis at the individual level suggests that the vertical integration of villages has a positive effect on trust preferences for all village inhabitants. Apart from contract participation increased investments in transportation and market infrastructure likely also increased the integration of non-contract participants into markets.
\end{abstract}

\subsection{Introduction}

Ever since Putnam et al. (1993) introduced the concept of social capital to the economic realms, economists have started to relate it to economic performance. In this regard, trust as an aspect of social capital plays an important role. Trust among market actors reduces transaction costs, increases the frequency of successful transactions and long-term rewards (Bowles, 1998). In cross-country analyses and in more disaggregated contexts trust has frequently been found to be associated with economic growth (Knack and Keefer, 1997; Narayan and Pritchett, 1999; Den Butter and Mosch, 2003; Beugelsdijk and van Schaik, 2005; Bengtsson et al., 2005; Tu and Bulte, 2010). Considering these 
beneficial effects for economic development, scholars have sought to explore the determinants of trust.

Putnam et al. (1993) note that trust evolves by participating in various social environments within and outside individuals' own groups where they experience trusting behavior. Translated to the market place as a social environment, Arrow (1972) argues that every business interaction among market actors has an element of trust. Specifically in developing countries, where rural economies are often characterized by spot markets, social relations among market actors are often personalized (e.g. family, kin, friends) and based on reciprocity (Fafchamps and Minten, 2001). In these economies, establishing formal contracts and, closely related monitoring compliance, may frequently be too costly. As a consequence, weak or absent formal institutions are often substituted for by trust that governs social relationships among market actors. Since interactions mainly occur with known others, their resulting trust relationships can be considered personalized.

Rural economies in many developing countries are in transition, and as a result, markets become increasingly formal and interaction among actors more anonymous. In this regard, Meijerink et al. (2014) study the effects of the creation of a formal trading structure on personalized trust on the Ethiopian sesame market. They report that, after the emergence of a formal trading scheme, personalized trust for export traders has deteriorated. In contrast, for 'other' traders who still partly operate within the traditional system, personalized trust increased. Thus, the emergence of formalized markets may have deteriorating effects on personalized trust. Possibly, traders who started interacting with anonymous others developed a different form of trust: generalized trust (i.e. trust in anonymous others). This conjecture would be consistent with Henrich et al., (2001), who argue that increased market integration stimulates the creation of a positive attitude towards strangers and consequently generalized trust. Also in cross-country comparisons and behavioral experiments, increased market integration has been found to be conducive to generalized trust (e.g. Berggren and Jordahl, 2006; Fischer, 2008; Henrich et al., 
2010). In contrast, in another study conducted in Mozambique and Zimbabwe, Siziba and Bulte (2012) report evidence of a negative effect of market integration (i.e. crop marketing) on generalized trust. The authors conjecture that this may be due to the exploitation of inexperienced farmers by experienced traders. Taken together, whether integration into more formal and thus anonymous markets promotes or impedes generalized trust preferences likely depends on the specific context.

Among other modes of market integration, contract farming can be mentioned. The link with generalized trust, however, is not straightforward. On the one hand, contracts may be perceived as the basis for trust to evolve because it limits opportunities and opportunistic behavior. In turn, contractual relationships have also been argued to be detrimental to trust because contracts may be perceived as a sign for distrust. Under these circumstances control (i.e. monitoring compliance) and sanction mechanisms (i.e. threat of litigation) are required to maintain the formal relationship. Such contracts may lead to conflict, opportunism and defensive behavior (Lyons and Mehta, 1997) and thus reducing trust levels (Woolthuis et al., 2005). In sum, more empirical research is needed that takes into account the context-specificity that is likely to shape social preferences, such as trust.

The main objective of this chapter is to contribute to the empirical literature on the determinants of trust. Specifically, we examine if integration in formalized markets through contract farming - is conducive to generalized trust. Likewise, we investigate if increased integration in formalized markets has a positive effect on generalized trust. To do so, we use a measure of trust that is elicited through a behavioral experiment. This is in contrast to the use of simple survey questions to record trust preferences, as it is frequently done in literature (e.g. Berggren and Jordahl, 2006; Fischer, 2008; Siziba and Bulte, 2012; Meijerink et al., 2014). Survey questions, as used in the World Value Survey often appear ill-suited to measure trust and respondents are not incentivized to answer truthfully (Glaeser et al., 2000). 
To address our objective we use the Indonesian oil palm sector as a study case. The arrival of oil palm in Indonesia in the 1970s was the start of major institutional changes. Large-scale agro-companies entered the sector and targeted entire village communities to access available land. In particular, vertical integration (i.e. contract farming schemes) introduced new relationships between contract participants and private companies, as it has been occurring in many countries (Swinnen and Maertens, 2007). Usually these emerging relationships between the market actors were more formalized and anonymized than before. This means that contracts instead of oral agreements constitute the relational basis and contract participants do business with an anonymous entity, such as 'the company' or 'the cooperative', instead of known fellow villagers.

In addition to the direct effects of contract farming schemes on contract participants, there are also indirect effects associated with vertical integration. Specifically, an emerging industry develops along investments into market and transportation infrastructure to increase the efficiency of business operations within the industry (Govereh and Jayne, 2003). In addition, substantial migration into the area likely occurred as a result of high labor demand. This offers opportunities for villagers who are not directly participating in contract schemes but who live in the same village. These villagers are likely to benefit from improved market access that allows them to participate in various markets with new and anonymous market actors (e.g. migrants).

Taken together, through the direct and indirect effects of vertical integration entire village communities underwent institutional changes. Thus, to examine the overall effects of formal market integration on generalized trust, we focus on the village level. However, although we hypothesize that both direct and indirect effects of vertical integration influence generalized trust, the village-level analysis does not allow an investigation of the relative importance of the respective effects. In different words, can we observe differences in generalized trust between contract-participants and nonparticipants who all together live in the same village? To investigate this we make use of behavioral and survey data at the individual level. 
This chapter is organized as follows. In the next section we outline the context of this study and give some background information on the institutional change in the oil palm sector. In Section 3, we present the materials and methods used in this study. Section 4 will discuss the main findings from the experiment and the regression analysis. Finally, Section 5 concludes.

\subsection{Study context}

The commercial cultivation of oil palm in Indonesia has started some three decades ago. From 1990-2012 the oil palm area increased tenfold to 6.65 million ha (FAOSTAT, 2014). This tremendous expansion has played a crucial role for spurring economic development and opportunities to alleviate poverty (Zen et al., 2005). As we will see, in this regard contract farming played a crucial role.

This study was implemented in Jambi province, which during the last 20 years has been characterized by rapid oil palm expansion (Gatto et al., 2014). Oil palm was introduced by large-scale vertically integrated estates. In exchange for subsidized capital and access to land concessions, companies integrated smallholder farmers in surrounding villages through contract farming arrangements (Feintrenie et al., 2010a). Villages in which oil palm contract schemes were implemented underwent considerable institutional changes. In particular, new and formalized relationships were introduced between an anonymous entity (i.e. the company) and farmers. Specifically, formal contracts clearly defined responsibilities of the respective parties regarding, for instance, the delivery of inputs and technical assistance as well as output prices. ${ }^{11}$ Furthermore, farmers participated in loan repayment schemes to repay the granted loans required for land clearing and plot establishment (Larson, 1996). The institutional change also involved increased coordination and opportunities for collective action. For example, farmer cooperatives or

\footnotetext{
${ }^{11}$ For further information on contract conditions we refer the reader to Feintrenie et al. (2010a).
} 
farmer groups were frequently established as an intermediary between the company and the farmers (McCarthy and Cramb, 2009).

In those villages that were not included in the emerging oil palm sector, local communities largely rely on rubber as their main agricultural activity. However, in contrast to the oil palm sector, the Jambinese rubber market is characterized by what Fafchamps and Minten (2001) call a 'flea market economy'. The relationship between farmers and traders are frequently informal and interactions take place on a cash-andcarry basis. In addition farmers and traders have marketing agreements which are enforced by credit dependencies and trust-based relationships (Akiefnawati et al., 2010).

The expansion of the oil palm sector in the research area was accompanied by substantial investments by the Indonesian government, in particular to develop transportation and market infrastructure (Larson, 1996). This resulted in decreased transaction costs associated with the logistics and commercialization of oil palm fruits, but also more generally contributed to improved market access in the respective villages. In addition, the large influx of migrants to the area contributed to the creation of new markets with anonymous actors (Budidarsono et al., 2013).

\subsection{Materials and methods}

\section{Sampling strategy}

For this study, we purposively selected five districts in the Sumatran province of Jambi, Indonesia. Selection was based on the criterion to include spatial areas which are characterized by recent agricultural transformations towards monoculture rubber and oil palm. To further account for spatial variability we randomly selected five sub-districts per district. Next, in each of the sub-districts we further selected 4 villages on a random basis to arrive at the total sample of 100 village communities. As discussed, due to logistical difficulties we had to drop two villages. For the sample selection we relied on 
an extensive list of villages from PODES. However, due to ethical concerns village elite raised in some villages regarding the economic experiment, we refrained from conducting it in all selected villages. ${ }^{12}$ As a result, for this study we draw on a total sample of 91 villages.

Through a structured village survey we gathered information about the village communities by organizing group interviews with key villagers (i.e. village head, secretary, group leaders, elderly). In particular, we collected data on certain village aspects, such as village assets, land-use change, demographics, institutions, technology use, contractual arrangements with companies, etc. Six students from Jambi University facilitated the group interviews which were held in Bahasa Indonesia. Prior to data collection we extensively trained our enumerators. Data collection took place between September and December 2012.

\section{Trust experiment}

Most of the mentioned studies which investigate the relationship between formal market integration and informal institutions measure trust with survey questions (e.g. Knack and Keefer, 1997; Beugelsdijk and van Schaik, 2005; Bengtsson et al., 2005; Meijerink et al., 2014). It has been argued that survey questions, as posed in the World Value Survey fail to adequately measure trust, instead trustworthiness is captured (Glaeser et al., 2000). Therefore, for this study we conducted a behavioral experiment to elicit respondents' generalized trust preferences.

Regarding the experimental setup, we followed the traditional format of the wellestablished economic experiment, as pioneered by Berg et al., (1995). Basically, two players are randomly paired to one another and both receive an endowment of Indonesian

\footnotetext{
${ }^{12}$ Ethical concerns were mainly related to the perceived fairness of our recruitment strategy; only a random draw of villagers could participate in the game and receive a reward, whereas others were randomly excluded. In all villages we played the game only with prior consent of the village elite.
} 
Rupiah (IDR) $20,000^{13}$ each. We framed this as a show-up fee. Next, the first-mover the sender - is invited to send any amount between 0 and IDR 20,000 to an anonymous second player - the receiver. Before the sender makes his/her decision (s)he is told that any amount sent would be tripled. By tripling the amount sent, we induce socially efficient behavior. Once the receiver receives the amount sent, (s)he is deliberate in the amount returned to the sender. Of course, the combined payoff is maximized if the sender sends his/her total endowment, whereas both players equally benefit from the maximized payoff if the receiver returns half of his total endowment. The amount sent by the sender is generally been treated as his/her trust preference. In case the sender does not trust the receiver to return anything, (s)he would send nothing. Since the game was played anonymously and thus participants were not aware of the identity of their partners in the game ${ }^{14}$, we elicit generalized as opposed to personalized trust preferences. To explain the game we used a script which was translated to Bahasa Indonesia and read-out in front of the participants (see Appendix C) ${ }^{15}$.

In total, 902 individuals participated in the experiment. Out of our pool of 91 villages we randomly selected our respondents. We assigned slightly more participants $(\mathrm{N}=474)$ to the role of the sender than to the role of the receiver $(\mathrm{N}=428)$. The reason is the following. The selected respondents did not all show up at the experiment, leaving us with an unequal number of participants. When this occurred we tried to replace the absent respondent; however, this was often not feasible. Also, to 'disinvite' an already selected participant to get an equal number of senders and receivers was due to ethical concerns not justifiable. Therefore, in case we had more senders than receivers we

\footnotetext{
${ }^{13}$ At the time of the data collection USD 1 exchanged into IDR 9,500. On average the wage rate in our study region was IDR 60-70 thousand per day.

${ }^{14}$ Usually, we conducted the experiment in a public building (e.g. school, office village head). In doing so, we attempted to increase the privacy of the decisions of the participants. Prior to experiment start, we stressed the importance of keeping all information exchanged with us to themselves and kindly ask them to not talk to fellow participants. Throughout the course of the experiment, the group of participants was constantly supervised by one or more enumerators.

${ }^{15}$ To avoid an 'order' bias to drive our results each of the three teams of enumerators had a different order of examples used to explain the game.
} 
randomly assigned one sender to another participating receiver. This strategy allowed us to elicit the sender's behavior without reducing the number of participants. After we conducted the trust experiment respondents participated in a short individual survey which covered basic socioeconomic data, such as sex, age, years of education, household size, social participation, contract farming participation.

\section{Empirical strategy}

We want to explore how generalized trust varies across villages with (increased) formal market integration. To model this, we specify the following OLS model:

Trust $_{v}=\alpha_{1}+\beta_{1}$ market integration $_{v}+\gamma_{1} X_{v}+\varepsilon_{v}$,

where Trust $_{v}$ is the aggregated generalized trust measure for village $v$, the $\alpha$ 's, $\beta$ 's and $\gamma$ 's are parameters to be estimated, and $\varepsilon_{v}$ is an i.i.d. error term. Aggregated generalized trust was calculated as the mean amount sent (by the senders) for each village based on

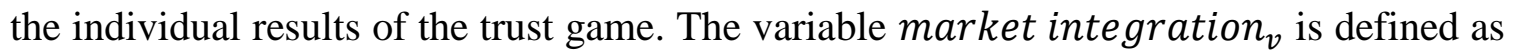
a dummy variable that captures if a village $v$ is vertically integrated, that is a contract was signed in village $v$ at some point (we refer to these villages as contract village). Further,

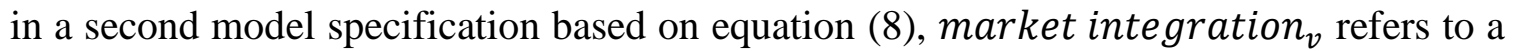
continuous variable that captures the possible long-term effects of increasing market integration (we refer to this variable as contract length). The values of contract length refer to the number of years that have passed since the contract was signed in village $v$ (i.e. $2012=1,2011=2, \ldots, 1986=27$ ).

The vector of variables $X_{v}$ includes various village characteristics to control for confounding factors related to (i) basic village aspects, (ii) general market access, and (iii) social capital. Regarding the first, we control for population density, WI, if a village is dominated by an indigenous or migrant population, and conflict related to land and 
contracts. With respect to general market access, we control for the distance to the closest market, and if commercial logging took place in the village. Finally, we include a range of variables related to a village's social capital: village homogeneity, village neighborhood density, mosque density and if it is possible to sanction the village head for misbehavior. Table 13 provides a description of the variables included in the model. Finally, to capture unobserved heterogeneity at the district level, we also include district fixed effects.

In the literature, it is often stressed that generalized trust and market participation may be determined simultaneously (e.g. Alesina and La Ferrara, 2002; Berggren and Jordahl, 2006; Fischer, 2008; Tu and Bulte, 2010). As discussed, we expect the integration in formal markets to have a positive effect on trust preferences. Yet, individuals with higher generalized trust levels may also be more likely to engage in market activities. ${ }^{16}$ Likewise, increased aggregated trust at the village level may reflect the general attitude of cohorts of villagers towards the good intentions of private companies and thus their willingness to engage in contract farming schemes. Therefore, in the above model specifications the contract variables may be endogenous. To address this issue, we employ an IV estimator in addition to OLS. We identified investor visit as a good instrument. Prior to contract adoption, an oil palm investor visits the village to explain about oil palm cultivation and to propose a contract. Investor visit is highly correlated with contract adoption but it is less likely that investors affect generalized trust preferences directly. In this regard, first, building trust is likely a process that takes longer than a couple of visits and, second, repeated interaction with a known investor likely affects personalized instead of generalized trust. In sum, we believe that the effect of our instrument on generalized trust preferences is channeled through contract adoption. There is no reason to believe that trust has an influence on the probability of investor visit.

\footnotetext{
${ }^{16}$ For example, see Woolthuis et al. (2005) who argue that a certain trust level is required to engage in contract negotiations.
} 
Apart from the village-level analysis we want to understand if there are differences in generalized trust between contract-participants and non-participants who live in the same village all together. To do so, we utilize our behavioral and survey data at the individual level. The following equation models individual generalized trust as a function of individual-specific and village-specific variables:

Trust $_{i}=\alpha_{2}+\beta_{2}$ contract $_{i}+\gamma_{2} X_{i}+\delta X_{v}+\varepsilon_{i}$

where Trust $_{i}$ refers to the amount sent (by the senders) in the experiment of individual $i ; \alpha, \beta, \gamma$ and $\delta$ are parameters to be estimated, and $\varepsilon_{i}$ is an i.i.d. error term. The variable contract $_{i}$ is a dummy variable that equals one if an individual $i$ participates in contract farming and zero if individual $i$ does not participate in contract farming. The vector of variables $X_{i}$ includes individual-specific control variables (e.g. sex, age, years of education, household size). Finally, to control for confounding factors at the village level, $X_{v}$ includes variables related to village-specific social capital and market access.

Similar to the village-level analysis, contract $_{i}$ may be endogenous. In contract villages, the farmer's decision to adopt a contract may be influenced by ex ante trust preferences. Therefore, an IV approach is employed to address the endogeneity stemming from reverse causality issues. We identified the share of oil palm land at the village level as an instrument. We argue that within contract villages the share of oil palm land is correlated with the incidence that a farmer participates in a contract farming scheme. Probably, the larger the share of oil palm land in a given contract village, the more likely it is that an individual is participating in a contract scheme. In contrast, at the individual level the decision to participate in contract farming cannot influence the share of oil palm land at the village level. Likewise, it is unlikely that the outcome variable trust $_{i}$, as a measure at the individual level, affects the share of oil palm land, as a variable at the village level. Overall, we argue that the effect of the instrument on the outcome variable is channeled through the endogenous variable. 
Finally, to examine individual generalized trust differences between contract and noncontract participants, we focus on contract villages only. As a consequence, we exclude those villages where no contract was signed. ${ }^{17}$

\subsection{Results}

\section{Descriptive results}

We start with the presentation of the experimental results. The amount sent by the respondents in the trust experiment amounts to IDR 8,428 (Table 10). Considering the initial endowment (IDR 20,000), on average the fraction sent was 0.42. In turn, the average amount returned by the receiver in the game amounted to IDR 17,334. These findings are consistent with earlier empirical work conducted in the lab with students and in the field with farmers around the world (see Cardenas and Carpenter, 2008).

Based on the individual behavioral experimental outcomes, at the village level the average aggregated amount sent amounts to IDR $8,453^{18}$ (Table 11). Comparing contract villages $(\mathrm{N}=33)$ with non-contract villages $(\mathrm{N}=58)$ reveals differences in trust levels. In this regard, respondents in contract villages sent on average almost IDR 650 more than respondents in non-contract villages, IDR 8,868 and IDR 8,216, respectively. The difference is statistically significant at the $10 \%$ level. This provides a descriptive

\footnotetext{
${ }^{17}$ Alternatively, we could have formulated equation (9) in such a way that we would not have to exclude the villages without a contract. Variables included would be contract $_{i}$ that captures if an individual $i$ has a contract or not, and contract $_{v}$ which captures if a contract exists in a given village $v$. In this specification the coefficient for contract $_{i}$ captures the difference in trust between contract and non-contract participants who live in the same village. In contrast, the coefficient for contract $_{v}$ captures trust levels for noncontract participants who live in a contract village. In this model both variables, contract $_{i}$ and contract $_{v}$, are possibly endogenous. Unfortunately, we were unable to identify two valid instruments at the same time. Therefore we decided to exclude the non-contract villages. This allows us to deal with only one endogenous variable.

${ }^{18}$ The attentive reader may have noticed that the average amount sent differs between the individual and the village level. This is mainly due to rounding mean values. Remember that the mean values at the village level are based on mean trust values at the individual level which.
} 
indication that increased market integration is positively associated with generalized trust.

Table 10. Descriptive results of individual trust levels for contract villages

\begin{tabular}{lccccc}
\hline & $\begin{array}{c}\text { Total sample } \\
(\mathrm{N}=474)\end{array}$ & $\begin{array}{c}\text { Contract } \\
\text { village } \\
(\mathrm{N}=168)\end{array}$ & $\begin{array}{c}\text { Contract } \\
\text { participants } \\
(\mathrm{N}=41)\end{array}$ & $\begin{array}{c}\text { Non- } \\
\text { participants } \\
(\mathrm{N}=127)\end{array}$ & $\begin{array}{c}\text { T-test } \\
\text { (p-value })\end{array}$ \\
\cline { 2 - 6 } & $(1)$ & $(2)$ & $(3)$ & $(4)$ & $(3)-(4)$ \\
\hline Trust & 8,428 & 8,929 & 9,682 & 8,685 & 0.13 \\
(amount sent) & $(5,137)$ & $(4,973)$ & $(5,321)$ & $(4,852)$ & \multirow{2}{*}{} \\
\hline
\end{tabular}

Notes: Mean values; standard deviations in parentheses.

Table 11. Descriptive results of aggregated trust levels

\begin{tabular}{lcccc}
\hline & $\begin{array}{c}\text { All villages } \\
(\mathrm{N}=91)\end{array}$ & $\begin{array}{c}\text { Non-contract } \\
\text { village } \\
(\mathrm{N}=58)\end{array}$ & $\begin{array}{c}\text { Contract } \\
\text { village } \\
(\mathrm{N}=33)\end{array}$ & $\begin{array}{c}\text { T-test } \\
(\mathrm{p} \text {-value })\end{array}$ \\
\cline { 2 - 5 } & $(1)$ & $(2)$ & $(3)$ & $(2)-(3)$ \\
\hline Trust (amount sent) & $\begin{array}{c}8,453 \\
(2,345)\end{array}$ & $\begin{array}{c}8,216 \\
(2,439)\end{array}$ & $\begin{array}{c}8,868 \\
(2,143)\end{array}$ & 0.10 \\
\hline
\end{tabular}

Notes: Mean values; standard deviations in parentheses.

With respect to contract villages, individual respondents $(\mathrm{N}=168)$ sent on average IDR 8,928 in the trust game. Comparing contract participants $(\mathrm{N}=41)$ with non-contract participants $(\mathrm{N}=127)$ reveals that individuals who are contracted sent on average IDR 9,682 and non-contract participants IDR 8,685. The difference in the amount sent, however, is insignificant as Table 10 depicts. This also provides a first descriptive indication supporting our hypothesis that contract and non-contract participants exhibit similar trust preferences induced by direct and indirect effects stemming from increased market integration. 
Turning to the socioeconomic characteristics of the experiment participants, around 64\% of our respondents are male and average age is 42 years. Furthermore, respondents seem to be well educated having on average 8 years of schooling. For an extensive summary statistics see Table 12 .

Table 12. Summary statistics of experimental results and respondents

\begin{tabular}{lcccc}
\hline Variables & Mean & Std. Dev. & Min & Max \\
\hline Experimental variables & & & & \\
$\quad$ Aggregated Trust (amount sent) & 8,453 & 2,345 & 4,000 & 14,800 \\
Trust (amount sent) & 8,428 & 5,137 & 0 & 20,000 \\
Fraction sent (amount sent/20,000) & 0.421 & 0.257 & 0 & 1 \\
Trustworthiness (amount returned) ${ }^{\mathrm{t}}$ & 17,334 & 12,815 & 0 & 80,000 \\
Socioeconomic variables & & & & \\
Male (d) & 0.635 & 0.482 & 0 & 1 \\
Age & 42.01 & 11.74 & 18 & 76 \\
Years of education & 8.031 & 3.224 & 0 & 18 \\
Household size $_{\text {Truck ownership (d) }}$ & 4.616 & 1.538 & 1 & 11 \\
Contract $_{\text {variables }}$ & 0.932 & 0.268 & 0 & 1 \\
C-CV $^{\mathrm{a}}$ (d) & & & & \\
NC-CV $^{\mathrm{b}}$ (d) & 0.086 & 0.281 & 0 & 1 \\
NC-NCV $^{\mathrm{c}}$ (d) & 0.268 & 0.443 & 0 & 1 \\
\hline
\end{tabular}

Notes: 474 obs.; ${ }^{\mathrm{t}} 428$ obs.; ${ }^{\mathrm{a}} \mathrm{C}-\mathrm{CV}$ : contract-participant in contract village; ${ }^{\mathrm{b}}$ non-contract participant in contract village; ${ }^{\mathrm{c}}$ non-contract participant in non-contract village.

Table 13 describes and summarizes the socioeconomic village-level data. In terms of market integration, $60 \%$ of the sample villages were visited by an investor, a representative of an oil palm company. Conditional on investor visit, contracts are adopted. Considering our total sample, in $36 \%$ of the villages an oil palm contract was established. In addition, conditional on the existence of a contract the average length of a contract is 13.5 years. Considering the lifespan of oil palm trees of about 25 years, the average contract length suggests that the average contracted oil palm plantation reached full maturity. 
Table 13. Summary statistics and description of village-level variables

\begin{tabular}{|c|c|c|c|c|}
\hline Variable & Mean & Std. Dev. & Min & Max \\
\hline \multicolumn{5}{|l|}{ Contract variables } \\
\hline Investor visit (d) & 0.604 & 0.492 & 0 & 1 \\
\hline Contract village (d) & 0.363 & 0.483 & 0 & 1 \\
\hline $\begin{array}{l}\text { Contract length } \text { if contract village }=1 \\
(1=2012 ; 2=2011, \ldots, 27=1986)\end{array}$ & 13.52 & 6.519 & 1 & 27 \\
\hline \multicolumn{5}{|l|}{ Village-level controls } \\
\hline $\begin{array}{l}\text { Population density } \\
\text { (No. of villagers per ha; pop/village land) }\end{array}$ & 1.001 & 1.031 & 0.078 & 5.561 \\
\hline Wealth index ${ }^{a}$ & 0.744 & 0.135 & 0.352 & 1 \\
\hline $\begin{array}{l}\text { Indigenous village (d) (dominated by } \\
\text { indigenous group) }\end{array}$ & 0.604 & 0.492 & 0 & 1 \\
\hline Conflict in village (d) & 0.341 & 0.476 & 0 & 1 \\
\hline Distance to closest market $(\mathrm{km})$ & 6.267 & 7.791 & 0.011 & 48 \\
\hline Logging activities (d) & 0.593 & 0.494 & 0 & 1 \\
\hline $\begin{array}{l}\text { Village homogeneity } \\
\text { (share of dominant ethnical group) }\end{array}$ & 0.812 & 0.165 & 0.421 & 1 \\
\hline $\begin{array}{l}\text { Village neighborhood density } \\
\text { (No. of neighborhoods per } 1000 \text { villagers) }\end{array}$ & 1.874 & 0.957 & 0.556 & 4.324 \\
\hline $\begin{array}{l}\text { Mosque density } \\
\text { (No. of mosques per } 1000 \text { villagers) }\end{array}$ & 2.537 & 1.945 & 0.556 & 8.576 \\
\hline Sanction village head (d) & 0.604 & 0.492 & 0 & 1 \\
\hline $\begin{array}{l}\text { Share of oil palm land } \\
\text { (oil palm land/total village land) }\end{array}$ & 0.194 & 0.268 & 0 & 0.961 \\
\hline
\end{tabular}

Notes: Observations: $91 ;{ }^{\text {a }}$ wealth index is an index based on the relative share of households owning certain assets such as motorbike, car, truck, cellphone, fridge, etc. in a given village. We created the wealth index following Sahn and Stifel's (2003) approach. 
Regarding village-level characteristics, the mean population density equals one, meaning that on average one villager accounts for exactly one hectare of village land. Moreover, the mean village has a relative wealth score of 0.74 . This value is based on the share of households owning certain assets (such as motor, car, truck, television, satellite dish, fridge, mobile phone) in a given village as compared to other villages. ${ }^{19} \mathrm{Next}$, the mean distance to the nearest market is about six $\mathrm{km}$. Another source of market exposure and/or conflict stems from the presence of commercial logging activities in the village. We observe that about $60 \%$ of the villages were exposed to commercial logging activities at some point.

Furthermore, $60 \%$ of the sample villages are dominated by Jambi's indigenous ethnicity, the Melayu Jambi and thus have a more sedentary lifestyle. In contrast, the remaining $40 \%$ of the villages are dominated by either people who migrated spontaneously or who arrived in Jambi through a government-led relocation program (Budidarsono et al., 2013). Whereas the first group mainly migrated from other parts of Sumatra, the latter group has its origin in Java. Moreover, villages seem to be fairly similar in ethnical terms. On average, around $81 \%$ of the villagers belong to the same ethnicity.

Regarding social capital, we use various proxies that may influence trust. Here the idea is that trust is an outcome of bonding with people with the same affiliation (i.e. neighborhood, religious). Our sample villages on average consist of about two neighborhoods and 2.5 mosques per 1000 inhabitants. In addition, we use the possibility to sanction village heads for malpractice as a proxy for a democratic village community that is equipped with working institutions, and thus trust. It appears that in merely $60 \%$ of the villages the village heads can be sanctioned for malpractice.

Finally, villages have substantially been subject to conflict. In $34 \%$ of the villages conflicts exists between villagers and the government of private companies. These conflicts mainly revolve around contract-related and land issues. This supports earlier

\footnotetext{
${ }^{19}$ We constructed a wealth index as described in Sahn and Stifel (2003). In addition, we normalized the variable between 0 and 1 .
} 
findings on contractual conflicts that have often emerged as a result of lack of transparency and absence of free and prior consent (Rist el al., 2010). Also incidences of land issues have frequently been reported (Colchester et al., 2006).

\section{Market integration and generalized trust}

Table 14 depicts the regression results investigating the link between increased market integration and generalized trust at the village level. As a comparison, columns (1) and (2) show OLS estimates. As discussed, due to the endogeneity of the contract variables we also employ an IV approach. The columns (5) and (6) reveal the first stage estimation results. Here, the instrument - investor visit - significantly explains the contract variables at the $1 \%$ significance level. Overall the partial $F$ statistic is high enough to argue for the presence of a strong instrument.

Our results show that contract villages exhibit significantly higher generalized trust levels than non-contract villages. Specifically, the aggregated amount sent in contract villages was IDR 1,700 higher compared to non-contract villages (column 3). Furthermore, we examine if market integration has a long-term effect on generalized trust. Thus we predicted that generalized trust at the village level increases with increasing market integration. As a proxy for this we use the length of a contract (i.e. number of years that have passed since the contract was signed). Indeed, our data suggest that an additional year of contract length increases the amount sent by IDR 130 (column 4). It appears that generalized trust, rather than being static, is likely to increase over time with market integration. In addition, all estimation results are robust to the influence of confounding factors at the village and district level. 
Table 14. Determinants of aggregated generalized trust

\begin{tabular}{|c|c|c|c|c|c|c|}
\hline \multirow{4}{*}{ Variable } & \multirow{2}{*}{\multicolumn{2}{|c|}{ OLS }} & \multicolumn{4}{|c|}{ IV (2SLS) model } \\
\hline & \multirow{2}{*}{\multicolumn{2}{|c|}{ Amount sent }} & \multirow{2}{*}{\multicolumn{2}{|c|}{$\begin{array}{l}\text { Second stage } \\
\text { Amount sent }\end{array}$}} & \multicolumn{2}{|c|}{ First stage } \\
\hline & & & & & \multirow{2}{*}{$\begin{array}{c}\text { Contract } \\
\text { village }\end{array}$} & \multirow{2}{*}{$\begin{array}{c}\text { Contract } \\
\text { length }\end{array}$} \\
\hline & (1) & (2) & (3) & (4) & & \\
\hline Contract village $(\mathrm{d})$ & $\begin{array}{l}618.2 \\
(580.1)\end{array}$ & & $\begin{array}{l}1725^{*} \\
(1006.2)\end{array}$ & & & \\
\hline $\begin{array}{l}\text { Contract length } \\
(1=2012 ; 2=2011, \ldots, 27=1986)\end{array}$ & & $\begin{array}{l}70.36^{* *} \\
(33.83)\end{array}$ & & $\begin{array}{l}128.8^{*} \\
(72.76)\end{array}$ & & \\
\hline \multicolumn{7}{|l|}{ Village controls } \\
\hline Conflict (d) & $\begin{array}{l}-47.28 \\
(661.4)\end{array}$ & $\begin{array}{l}-143.6 \\
(661.2)\end{array}$ & $\begin{array}{l}-159.4 \\
(633.8)\end{array}$ & $\begin{array}{l}-276.1 \\
(646.8)\end{array}$ & $\begin{array}{l}0.095 \\
(0.099)\end{array}$ & $\begin{array}{l}2.175 \\
(1.573)\end{array}$ \\
\hline Population density & $\begin{array}{l}-46.21 \\
(279.2)\end{array}$ & $\begin{array}{l}-89.49 \\
(259.9)\end{array}$ & $\begin{array}{l}-49.19 \\
(234.31)\end{array}$ & $\begin{array}{l}-126.9 \\
(230.8)\end{array}$ & $\begin{array}{l}0.035 \\
(0.048)\end{array}$ & $\begin{array}{l}1.058 \\
(0.929)\end{array}$ \\
\hline Wealth index & $\begin{array}{l}258.1 \\
(2007.2)\end{array}$ & $\begin{array}{l}428.6 \\
(1919.6)\end{array}$ & $\begin{array}{l}585.73 \\
(1837.9)\end{array}$ & $\begin{array}{l}704.4 \\
(1727.2)\end{array}$ & $\begin{array}{l}0.021 \\
(0.396)\end{array}$ & $\begin{array}{l}-1.696 \\
(5.652)\end{array}$ \\
\hline Distance to closest market (km) & $\begin{array}{l}-8.389 \\
(40.51)\end{array}$ & $\begin{array}{l}0.456 \\
(40.68)\end{array}$ & $\begin{array}{l}0.785 \\
(36.67)\end{array}$ & $\begin{array}{l}12.09 \\
(38.14)\end{array}$ & $\begin{array}{l}-0.007 \\
(0.005)\end{array}$ & $\begin{array}{l}-0.201 * * * \\
(0.075)\end{array}$ \\
\hline Logging activities (d) & $\begin{array}{l}452.4 \\
(631.8)\end{array}$ & $\begin{array}{l}501.4 \\
(631.4)\end{array}$ & $\begin{array}{l}490.7 \\
(604.7)\end{array}$ & $\begin{array}{l}559.9 \\
(596.4)\end{array}$ & $\begin{array}{l}0.011 \\
(0.095)\end{array}$ & $\begin{array}{l}-1.018 \\
(1.497)\end{array}$ \\
\hline Indigenous village (d) & $\begin{array}{l}1052.2 \\
(864.8)\end{array}$ & $\begin{array}{l}1073.4 \\
(847.8)\end{array}$ & $\begin{array}{l}1000.1 \\
(784.1)\end{array}$ & $\begin{array}{l}1066.8 \\
(770.3)\end{array}$ & $\begin{array}{l}-0.159 \\
(0.131)\end{array}$ & $\begin{array}{l}0.287 \\
(2.298)\end{array}$ \\
\hline Village homogeneity & $\begin{array}{l}-852.7 \\
(1643.9)\end{array}$ & $\begin{array}{l}-1018.3 \\
(1569.9)\end{array}$ & $\begin{array}{l}-491.7 \\
(1520.5)\end{array}$ & $\begin{array}{l}-988.4 \\
(1451.6)\end{array}$ & $\begin{array}{l}-0.014 \\
(0.321)\end{array}$ & $\begin{array}{l}2.892 \\
(4.884)\end{array}$ \\
\hline Village neighborhood density & $\begin{array}{l}193.7 \\
(239.2)\end{array}$ & $\begin{array}{l}158.6 \\
(223.5)\end{array}$ & $\begin{array}{l}89.11 \\
(216.9)\end{array}$ & $\begin{array}{l}80.69 \\
(207.9)\end{array}$ & $\begin{array}{l}0.082 \\
(0.051)\end{array}$ & $\begin{array}{l}1.328^{*} \\
(0.803)\end{array}$ \\
\hline Mosque density & $\begin{array}{l}55.16 \\
(217.2)\end{array}$ & $\begin{array}{l}25.42 \\
(207.7)\end{array}$ & $\begin{array}{l}-12.16 \\
(203.7)\end{array}$ & $\begin{array}{l}-30.67 \\
(198.4)\end{array}$ & $\begin{array}{l}0.029 \\
(0.035)\end{array}$ & $\begin{array}{l}0.765 \\
(0.576)\end{array}$ \\
\hline Sanction village head (d) & $\begin{array}{l}583.5 \\
(587.5)\end{array}$ & $\begin{array}{l}491.2 \\
(590.1)\end{array}$ & $\begin{array}{l}617.7 \\
(553.2)\end{array}$ & $\begin{array}{l}430.2 \\
(559.5)\end{array}$ & $\begin{array}{l}0.019 \\
(0.105)\end{array}$ & $\begin{array}{l}1.676 \\
(1.439)\end{array}$ \\
\hline \multicolumn{7}{|l|}{ Instrument } \\
\hline Investor visit (d) & & & & & $\begin{array}{l}0.528 * * * \\
(0.084)\end{array}$ & $\begin{array}{l}7.085^{* * *} \\
(1.388)\end{array}$ \\
\hline Constant & $\begin{array}{l}7374.7 * * * \\
(2216.5) \\
\end{array}$ & $\begin{array}{l}7564.6^{* * * *} \\
(2163.1) \\
\end{array}$ & $\begin{array}{l}6915.5 * * * \\
(2044.8) \\
\end{array}$ & $\begin{array}{l}7509.2^{* * *} \\
(1955.4)\end{array}$ & $\begin{array}{l}-0.273 \\
(0.442) \\
\end{array}$ & $\begin{array}{l}-8.557 \\
(5.651) \\
\end{array}$ \\
\hline District fixed effects & YES & YES & YES & YES & YES & YES \\
\hline $\mathrm{R}^{2}$ & 0.12 & 0.15 & 0.08 & 0.12 & & \\
\hline Adjusted $\mathrm{R}^{2}$ & & & & & 0.28 & 0.24 \\
\hline Partial F first stage & & & & & 41.08 & 26.38 \\
\hline \multicolumn{7}{|l|}{ Test of exogeneity } \\
\hline Robust score $\operatorname{chi}^{2}(1)$ & & & 1.76 & 0.99 & & \\
\hline
\end{tabular}

Notes: Number of observations: 91; robust std. errors in parentheses; $* * *$ statistical significant at the $1 \%$ level; **statistical significant at the $5 \%$ level; *statistical significant at the $10 \%$ level. 


\section{Indirect Market Participation Effects}

We now analyze the indirect effects of the emergence of formalized vertical integration into the oil palm sector on generalized trust. To this end, we utilize our individual dataset. In particular, we want to find out if there are trust differences between contract participants and non-participants living in the same village. An insignificant estimate would be in line with our prediction that all village inhabitants - irrespective of contract participation - drive the earlier found trust difference between contract and non-contract villages. As done before, we deal with the endogeneity of the contract variable by employing an IV strategy. Generally, the identified instrument - share of oil palm land performs well. In the first stage it is significantly correlated with the endogenous variables (Table 15 column 6) and the partial $F$ statistic suggests for the presence of a fairly strong instrument.

To start with, as robustness check for our significant findings at the village level we reran the earlier regression using the individual dataset and similar sets of village controls (column (1) and (3) depict the estimation results for OLS and 2SLS, respectively). Overall, we can confirm the earlier significant findings.

Using the individual dataset and the total sample also allows us to control for individual characteristics. Apart from the dummy variable male capturing the gender of the respondent, the included individual controls enter insignificantly. Regarding the dummy, the data reveal that male respondents on average sent IDR 1,272 more compared to their female fellows (column 3). A possible explanation could be that male respondents acted more strategically in the experiment. As Buchan et al. (2008) argue the only option to increase personal wealth is by trusting the respondent (i.e. sending more money). However, analyzing if trust differences among male and female respondents are due to strategic behavior in the experiment or more related to social preferences (Croson and Buchan, 1999) goes beyond the scope of this research. 
Table 15. Estimation results for indirect trust effects

\begin{tabular}{|c|c|c|c|c|c|c|}
\hline \multirow[b]{4}{*}{ Variable } & \multirow{2}{*}{\multicolumn{2}{|c|}{ OLS }} & \multicolumn{4}{|c|}{ IV (2SLS) model } \\
\hline & & & \multirow{2}{*}{\multicolumn{2}{|c|}{$\begin{array}{l}\text { Second stage } \\
\text { Amount sent }\end{array}$}} & \multicolumn{2}{|c|}{ First stage } \\
\hline & \multicolumn{2}{|c|}{ Amount sent } & & & \multirow{2}{*}{$\begin{array}{c}\begin{array}{c}\text { Contract } \\
\text { village }\end{array} \\
\text { Total } \\
\text { sample } \\
\text { (obs. 474) }\end{array}$} & \multirow{2}{*}{$\begin{array}{c}\begin{array}{c}\text { Contract } \\
\text { farmer }\end{array} \\
\begin{array}{c}\text { Only } \\
\text { contract } \\
\text { villages }\end{array} \\
\text { (obs. 168) }\end{array}$} \\
\hline & $\begin{array}{c}\text { Total } \\
\text { sample } \\
\text { (obs. 474) }\end{array}$ & $\begin{array}{c}\text { Only } \\
\text { contract } \\
\text { villages } \\
\text { (obs. 168) }\end{array}$ & $\begin{array}{c}\text { Total } \\
\text { sample } \\
\text { (obs. 474) }\end{array}$ & $\begin{array}{c}\text { Only } \\
\text { contract } \\
\text { villages } \\
\text { (obs. 168) }\end{array}$ & & \\
\hline & (1) & (2) & (3) & (4) & (5) & (6) \\
\hline Contract Village (d) & $\begin{array}{l}962.9^{*} \\
(523.8)\end{array}$ & & $\begin{array}{l}1887.3 * * \\
(970.3)\end{array}$ & & & \\
\hline Contract Participant (d) & & $\begin{array}{l}372.5 \\
(1014.7)\end{array}$ & & $\begin{array}{l}736.9 \\
(3858.9)\end{array}$ & & \\
\hline \multicolumn{7}{|l|}{ Individual Controls } \\
\hline Male (d) & $\begin{array}{l}1216.7 * * \\
(505.9)\end{array}$ & $\begin{array}{l}147.9 \\
(798.9)\end{array}$ & $\begin{array}{l}1272.8^{* *} \\
(501.1)\end{array}$ & $\begin{array}{l}113.8 \\
(881.9)\end{array}$ & $\begin{array}{l}-0.058 \\
(0.039)\end{array}$ & $\begin{array}{l}0.116^{*} \\
(0.065)\end{array}$ \\
\hline Age & $\begin{array}{l}34.27 \\
(23.53)\end{array}$ & $\begin{array}{l}65.16 \\
(42.49)\end{array}$ & $\begin{array}{l}36.79 \\
(23.61)\end{array}$ & $\begin{array}{l}61.73 \\
(52.78)\end{array}$ & $\begin{array}{l}-0.003 \\
(0.002)\end{array}$ & $\begin{array}{l}0.009 * * \\
(0.003)\end{array}$ \\
\hline Years of education & $\begin{array}{l}85.41 \\
(75.31)\end{array}$ & $\begin{array}{l}138.5 \\
(124.1)\end{array}$ & $\begin{array}{l}93.62 \\
(75.14)\end{array}$ & $\begin{array}{l}139.5 \\
(118.8)\end{array}$ & $\begin{array}{l}-0.012 * * \\
(0.006)\end{array}$ & $\begin{array}{l}-0.003 \\
(0.011)\end{array}$ \\
\hline Household size & $\begin{array}{l}-72.62 \\
(176.9)\end{array}$ & $\begin{array}{l}-51.73 \\
(323.2)\end{array}$ & $\begin{array}{l}-87.16 \\
(175.4)\end{array}$ & $\begin{array}{l}-48.25 \\
(310.6)\end{array}$ & $\begin{array}{l}0.023^{*} \\
(0.012)\end{array}$ & $\begin{array}{l}-0.012 \\
(0.027)\end{array}$ \\
\hline Truck ownership (d) & $\begin{array}{c}-732.9 \\
(1394.7)\end{array}$ & $\begin{array}{l}-943.2 \\
(2553.5)\end{array}$ & $\begin{array}{l}-804.1 \\
(1353.6)\end{array}$ & $\begin{array}{l}-986.7 \\
(2388.1)\end{array}$ & $\begin{array}{l}0.176^{* * *} \\
(0.063)\end{array}$ & $\begin{array}{l}0.126 \\
(0.259)\end{array}$ \\
\hline \multicolumn{7}{|l|}{ Instruments } \\
\hline Investor visit (d) & & & & & $\begin{array}{l}0.492 * * * \\
(0.031)\end{array}$ & \\
\hline Share of oil palm land & & & & & & $\begin{array}{l}0.379 * * * \\
(0.131)\end{array}$ \\
\hline Constant & $\begin{array}{l}6531.9 * * * \\
(1711.8)\end{array}$ & $\begin{array}{l}6020.2 * * \\
(2689.2)\end{array}$ & $\begin{array}{l}6067.1^{* * * *} \\
(1763.9)\end{array}$ & $\begin{array}{l}5992.4 * * \\
(2615.1)\end{array}$ & $\begin{array}{l}0.123 \\
(0.147)\end{array}$ & $\begin{array}{l}-0.162 \\
(0.251)\end{array}$ \\
\hline Village controls & YES & YES & YES & YES & YES & YES \\
\hline $\mathrm{R}^{2}$ & 0.04 & 0.04 & 0.03 & 0.04 & & \\
\hline Adjusted $\mathrm{R}^{2}$ & & & & & 0.36 & 0.12 \\
\hline Partial F first stage & & & & & $245.7 * * *$ & $8.47 * * *$ \\
\hline \multicolumn{7}{|l|}{ Test of exogeneity } \\
\hline Robust score chi ${ }^{2}(1)$ & & & 1.16 & 0.01 & & \\
\hline
\end{tabular}

Notes: Robust std. errors in parentheses; ***statistical significant at the $1 \%$ level; *statistical significant at the 5\% level; *statistical significant at the $10 \%$ level; village controls include distance to market, village neighborhood density, mosque density, village homogeneity. 
The main finding derived from Table 15 is the following. Conditional on living in a contract village, the data suggest that the difference in trust levels is insignificant between contract participants and non-participants. This finding supports our expectation that indirect effects from vertical integration, induced by improved market and transportation infrastructure and migration into the area, on trust preferences are possible. In contrast to contract participants who likely increased their generalized trust levels through repeated interaction in contract farming schemes, non-contract participants' increased generalized trust may be a result of a different influence. Specifically, we conjecture that non-contract participants increasingly participate in emerging markets with more anonymous market actors, such as migrants who settled in proximity to the oil palm industry to work as labor and smallholders on the estates. This likely also introduced more formalized relationships that go beyond oral agreements and personalized trust-based relationships. The results are similar for both OLS and using a IV estimator (column 2 and 4). In addition, the results are robust to confounding factors at the individual and village level.

\subsection{Conclusion}

In this chapter we investigate the effects of formalized market integration on generalized trust at the village level. We hypothesize that market integration in the oil palm sector had direct and indirect effects on villagers' generalized trust preferences. Direct effects mainly stem from participation in contract farming and repeated interaction with anonymous business actors in a formalized manner. Indirect effects, induced by investments made to improve market and transportation infrastructure, and increased interaction with anonymous market actors (i.e. migrants), possibly also affected villagers who did not directly participate in contract farming schemes. To capture these direct and indirect effects of market integration we focus the analysis on the village level. To arrive at a village-level trust measure, we aggregated the individual trust preferences that were elicited with a behavioral experiment. 
We find that aggregated generalized trust levels are higher in villages that are vertically integrated in the oil palm sector through contract farming schemes. It appears that, generally, contract farming provides the market actors with a stable environment that appears to limit opportunities but also opportunistic behavior (Woolthuis et al., 2005). In case no party defaults on the contract partnership such a formalized business environment seems to be conducive to the development of generalized trust. In our study region conflicts emerge, revolving around land and contractual issues, that may shatter contractual relationships. However, the findings suggest that this is not the case. Possibly, conflicts that affect the entire village are less likely to considerably affect the preferences of individual villagers. Unfortunately, due to data constraints we are unable to further investigate if conflict experienced at the individual level has negative effects on individual trust preferences. In a similar vein, Siziba and Bulte (2012) also conjecture that their observed lowered generalized trust levels are due to conflict between farmers and traders. This provides an interesting avenue for future research.

Furthermore, the data suggest for the presence of long-term effects of market integration. In this regard, villages that are for a longer period of time vertically integrated (proxied by the number of years that have passed since the contract was signed) reveal higher generalized trust preferences. We also investigated the relative importance of the direct and indirect effects of market integration on generalized trust. To do so, we conducted the analysis at the individual level. The data suggest that, within contract villages, contract participants and non-contract participants have similar generalized trust preferences. This provides tentative evidence that the found increases in aggregated trust preferences at the village level is not driven by contract participants only (direct effect), but that non-contract participants also increased their trust preferences as a result of being exposed to indirect effects of an emerging oil palm sector.

Overall, the results are in line with earlier finding from cross-country analyzes supporting a positive relationship between increased market integration and generalized trust (e.g. Berggren and Jordahl, 2006; Fischer, 2008; Henrich et al., 2010). However, in 
a more micro study setting other studies have found evidence for a negative relationship between market integration and trust (see for instance Siziba and Bulte, 2012). Although we find a positive effect of market integration on generalized trust the overall literature presents mixed results. Possibly, these are due to the context-specificity under which generalized trust evolves. But also more technically, the mixed findings may be a result of applying two different measures of trust which are either based on survey questions or on behavioral experiments. We encourage further research to confirm our findings for contract farming within the oil palm sector. At the same time, research is needed to expand our understanding of how generalized trust is affected by increased market integration. This would require to account for different levels of analysis (i.e. individual, village), various measures of market integration (i.e. contract farming, crop marketing, calorie consumption) and, more technically, different measures of trust (i.e. survey questions, behavioral experiment).

We acknowledge that this research has limitations and raises more questions. For example, the examination of long-term effects is based on cross-sectional differences between the sample villages. The use of a panel dataset for generalized trust preferences could provide an indication if trust has actually evolved in the same villages due to increased market integration. Furthermore, a question that comes up when looking at the results is what happens to personalized trust in villages that were vertically integrated but also where no contract was signed? Did personalized trust erode as a consequence of being integrated into markets. And likewise, did personalized trust remain unaffected in villages without a contract? That personalized trust is likely to erode due to the emergence of a formalized market integration has been reported by Meijerink et al. (2014). A further investigation for the oil palm sector is needed to further our understanding whether personalized and generalized trust preferences are complements or substitutes.

Finally, there are policy implications which can be drawn from our study. This research indicates that compared to an evolutionary process, social preferences may be affected by 
more short-term stimuli, such as the emergence of the oil palm sector. This may be of particular interest considering the virtuous circle which exists between market integration and generalized trust. In addition to the direct effects of contract farming arrangements, infrastructural improvements also positively contribute. Thus, further investments into rural infrastructure should be made to sufficiently connect, especially rural, villages to emerging markets. 


\section{Chapter 5}

\section{Conclusions}

\subsection{Synopsis}

During the past decades, various interrelated factors have encouraged governments to promote the development of their agricultural sectors. The major factors are, population growth, rising incomes and thus an increasing global demand for natural commodities, but also emerging opportunities to spur (rural) economic development, and being resilient to international price shocks. At first, agricultural sectors were largely financed by public investments. Later, many countries approved structural economic reforms that aimed to liberalize (agricultural) markets in a bid to attract private investments. This allowed large-scale private companies to enter agricultural sectors. At the same time, local smallholder farmers were involved extensively in agricultural sectors, largely through contract farming arrangements.

Overall, the promotion of agricultural sectors bears many challenges and opportunities alike. This is especially the case for rural areas where still most of the people deemed extremely poor are living as well as tropical areas where much of the world's natural richness can be found. In this dissertation, I analyzed the implications of an emerging agricultural sector in a specific rural and tropical region. In detail, I empirically investigated the effects of the emerging Indonesian oil palm sector on rural village communities in Jambi province, Sumatra. The overall study broke down into three specific areas: land-use dynamics, economic development, and institutional change. In this section, I will present the key findings of this dissertation. 


\section{Land-use dynamics}

Agricultural investments have transformed many rural tropical landscapes in developing and transition countries worldwide. Oftentimes, tropical areas have undergone considerable land-use changes towards perennial crops, and have experienced an immense reduction of their forest cover. Today, the oil palm expansion has often been held responsible for much of the observed negative environmental implications, associated with deforestation. But who is to blame? Whereas much of the oil palm cultivation is still under control of private large-scale agro-companies, local smallholder farmers have become increasingly important actors within the oil palm industry. In many studies at the macro level, private companies and smallholder farmers have often been clubbed together, which complicates the separation of the effects of agricultural investments on land-use dynamics and the related implications. Also, the empirical evidence for local village communities is scant. Additionally, many studies on land-use dynamics neglect to investigate the drivers of land-use change, specifically studies on oil palm.

To fill these gaps in the literature, I examined land-use dynamics at the village level of three land-use systems: oil palm, rubber, and forest. The dynamics were analyzed by looking at land-use over time. In particular, I focused on explaining village-level landuse in 2002 and 2012 by land-use from previous time periods as well as socioeconomic and policy variables. I showed that in spite of significant oil palm expansion, rubber remains the dominant crop in the study region. Furthermore, in contrast to many macrolevel findings, I found that oil palm was not a major driver of deforestation in the study region. Instead, past land-use changes towards rubber plantations and the timber industry were most likely the drivers. However, indirect effects on deforestation are possible since oil palm growth occurs in locations with ongoing logging activities. Although, I do not want to suggest that the oil palm expansion is not a driver of deforestation. The findings suggest that it is of major importance to distinguish between the actors involved in oil palm cultivation to make assumptions about who exactly is responsible for deforestation. 
In addition, I demonstrated the relevance of socioeconomic and policy factors in explaining land-use trajectories. Especially a relocation program was instrumental to the oil palm development. Mainly people from the densely populated islands Java and Bali were given resources and land in remote areas of Jambi to start cultivating oil palm. In contrast, many autochthonous villages have started growing oil palm later and expand their oil palm areas at a slower pace.

\section{Contract farming and economic development}

The Indonesian government promoted the establishment of private large-scale plantations which frequently involved cohorts of farmers in outgrower schemes under contract farming arrangements. Despite the fact that these arrangements have been in place already for almost as long as the arrival of oil palm in Indonesia, the empirical evidence on the potentially beneficial economic outcomes remains surprisingly scarce, mixed, and mostly based on descriptive analyses. In addition to the economic effects, I analyzed the inclusion of villages into the oil palm sector. The inclusion encompasses two aspects. First, an oil palm representative or investor targets certain villages suitable for being included into the oil palm industry. Second, conditional on being visited by an investor, usually cohorts of farmers organized in farmer cooperatives collectively adopt a contract. In the related literature, studies mainly focus on households' decisions to adopt a contract within villages. However, due to the collective decision, village-level factors likely play a decisive role in participating in contract farming schemes. Moreover, investigating the inclusion into the oil palm sector across villages allows for taking a broader perspective that could be useful for the formulation of policies. The research gaps were addressed by firstly investigating the factors that determine the inclusion of villages into the oil palm sector through contract farming schemes. Second, I evaluated the impact of this form of market integration on economic development at the village level. 


\section{Contract adoption}

Since the adoption of contract farming arrangements is conditional on an investor who visits a village to propose a contract, I investigated contract adoption as a two-step model. By controlling for the conditionality, I estimated the impact of village-level factors on the probability of contract adoption. The findings suggest that certain factors predicted that investors visited certain villages. In particular, these are the availability of village land, proxied by larger shares of village land characterized by steep land slopes, the proximity of a village to an oil palm mill and formal land titles.

Regarding land slopes, in Jambi province much of the flat land slopes can be found in areas that are under extensive agricultural cultivation (i.e. rubber). This may be better understood, knowing that rubber plantations were introduced many years before the advent of oil palm in Jambi province. Thus, conversely, steep land slopes may reflect (rural) areas characterized by little agricultural activities and, consequently, more available village land. Next, the proximity to an oil palm mill can be considered a plausible predictor of investor visit because shorter distances generally reduce transactions costs and guarantee that FFB are processed in a timely manner.

In addition, I found that formal land titles predict investor visit. I conjecture that this is a conflict avoiding strategy as community-company relationships have increasingly been afflicted with conflict. Next, conditional on being visited by an investor, the findings suggest that access to electricity discourages village communities to participate in contract farming schemes. I conjecture that these villages have few outside options to engage in business activities. This may be due to the location of villages in remoter areas which are often not connected to the public grid. Other variables are insignificant.

Overall, it appears that, at the village level, contract farming schemes have not been entirely equally accessible; however, I did not find evidence that the rural poor were excluded either. 


\section{Economic development}

Concerning the economic implications of contract farming, I proxied economic development by an index variable based on asset ownership. I demonstrated that compared to villages without a contract, contract villages have a significantly higher WI. Furthermore, the WI is also increasing as the group of farmers under contract becomes larger. A third estimation revealed that the WI is higher in villages that signed the contract earlier than those which did so more recently. However, after some point the positive effects diminish. Overall, it appears that the inclusion into the oil palm sector has stimulated economic development at the village level.

\section{Institutional change}

Finally, regarding institutional changes, I explored the effects of market integration into the oil palm sector on village institutions. Specifically, I wanted to understand how contract farming schemes, that introduce institutional changes towards more formalized and anonymous business relationships, affect generalized trust preferences at the village level. To date, the empirical evidence investigating the link between market integration and generalized trust remains scarce. This research aims to contribute to the empirical literature. In contrast to many previous studies that use survey questions to record trust preferences I elicited trust preferences through a behavioral experiment.

Explaining the behavioral by the survey data, I demonstrated that compared to villages where no contract was signed, contract villages exhibit significantly higher aggregated trust levels. I also showed the effects of long-term market integration: the longer the period of time that villages are integrated in contract farming schemes the higher the level of aggregated generalized trust. Moreover, to better understand the dynamics within contract villages, I further probed generalized trust differences between contract participants and non-contract participants. The findings revealed that, at the individual level, villagers who are not participating in contract schemes have no different trust 
preferences compared to their contracted fellows. I conjecture that this is a result of government investments in transportation and market infrastructure that integrated all villagers in contract villages into (emerging) markets.

\subsection{Policy recommendations}

Regarding the drivers of land-use change, especially concerning the expansion of oil palm, it can be concluded that a structural relocation program - the transmigration program - facilitated this process. This program has contributed to unequal developments between transmigrants and autochthonous people. For example, the Indonesian government provided transmigrants with agricultural land and a corresponding formal land title. This is a major advantage compared to the non-transmigrant population who has to endure an often costly and time-consuming administrative procedure to obtain formal land titles. In either case, land titles can improve access to credits which can be used to invest in/expand on current agricultural activities. Moreover, I demonstrated that land titles are important to attract oil palm businesses to the village which offers new agricultural opportunities. Therefore, the Indonesian government should promote an equal access to a transparent and affordable land titling process. Equally important, more effort is required by the regional and central government to produce accurate land maps which recognize existing customary land rights that still govern much of the autochthonous land.

Moreover, in line with case study reports I found that community-company partnerships are frequently afflicted with contractual and land conflicts. To avoid new conflicts, policies should aim at strengthening the bargaining position of local villages vis-à-vis

private companies. For instance, standardized and transparent bargaining protocols could support this.

In addition, I showed that formal market integration in the oil palm industry through contract farming schemes has substantially contributed to economic development in local 
village communities. From a policy perspective, the results show that the oil palm industry has indeed offered a viable strategy to spur rural economic development. At the same time, the increased market integration led to increased trust which, in turn, has often been found in the literature to be conducive to economic development. Further integrating villages into oil palm markets by investing in rural infrastructure could present a viable way to stimulate further virtuous circles between trust and economic development.

Finally, within the Jambinese oil palm industry I observed a change from large-scale agro-companies to more independent smallholder farmers. These have emerged as contracts expire and input and output markets develop. To continue the government's good intentions to promote economic development in rural areas, the Jambinese government should start to shift its focus on supporting independent smallholders. The same measures as already discussed - e.g. better access to a transparent and affordable land titling process and improving infrastructure - may work here as well. At the same time, opportunities of independent oil palm cultivation paired with an increasing population is likely to further pressure the existing land. Thus, future land-use changes towards oil palm are likely undertaken by independent smallholders, or more generally local communities. Sound policies need to be established to account for these developments by restricting the ongoing expansion in such a way that spares peat areas and tropical forests. A promising strategy to achieve this, for example, could be through an incentivizing mechanism, such as the Payments for Environmental Services.

\subsection{Limitations and future research}

This research is not without limitations. Here, I highlight the major ones and provide directions for future research. To start with, I make use of survey data to examine landuse dynamics and link these to socioeconomic and policy factors. Alternative methods such as remote sensing generate much more accurate land-use data. However, in spatially 
explicit models, factors that influence the observed land-use changes are oftentimes left unaddressed. Therefore, linking the socioeconomic data to land-use data that are collected through remote sensing could result in a fruitful combination of methods.

Furthermore, I analyzed land-use dynamics with a particular focus on oil palm considering land that belongs to communities rather than private companies or the government. Still, the largest share of oil palm land is cultivated by private oil palm companies. In addition, many leases granted to these private actors remain undeveloped. Although, I demonstrated the importance of local communities, continuous scrutiny of the overall oil palm sector is required to comprehensively evaluate future land-use dynamics in Jambi and elsewhere. Future research should also seek to clearly distinguish between the actors involved in oil palm cultivation.

In addition, I showed that economic development is positively associated with the integration in the oil palm industry through contract farming schemes. To arrive at this finding, I use asset ownership and a combination of the first and access to village facilities (i.e. health clinic and elementary school) as proxies for economic development at the village level. Future research could include alternative and more durable measures. For instance, the average income/consumption per capita could be used. As a more durable measure, future research could use factors that capture the investment into expanding agricultural activities (i.e. share of households buying land in and outside their village).

In this study I also demonstrated that market integration is conducive to trust. A behavioral experiment was conducted to elicit trust preferences. Specifically, the examination of long-term effects is based on cross-sectional differences between the sample villages. With the given data I was unable to examine how trust has evolved over time in the same villages due to increased market integration. Therefore, future research could employ a panel dataset on generalized trust to examine long-term effects on trust. 
Finally, this study uses a dataset that consists of three points in time, 1992, 2002 and 2012. The first two points in time are recalled. This strategy was chosen because of restricted data availability for previous years. Although data were collected through group interviews and cross-checked with secondary data sources for plausibility, the long recall period raises some concerns regarding data accuracy. Additionally, the time intervals between the years are rather large. As a consequence, I was unable to capture socioeconomic and land-use effects in the short-run. Creating a panel dataset without making use of a recalling strategy and shortening the time intervals to allow investigations for the short-run, could be dealt with in follow-up studies. 


\section{References}

Abood, S. A., Lee, J. S. H., Burivalova, Z., Garcia-Ulloa, J., Koh, L. P., 2014. Relative contributions of the logging, fiber, oil palm, and mining industries to forest loss in Indonesia. Conservation Letters.

Akiefnawati, R., Ayat, A., Alira, D., Suyitno, Joshi, L., 2010. Enhancing rubber production in communities around a village forest in Bungo District, Jambi Province. In: Leimona, B. and Joshi, L. (Eds.), Ecocertified natural rubber from sustainable rubber agroforestry in Sumatra, Indonesia. World Agroforestry Centre, Bogor. http://www.worldagroforestry.org/sea/Publications/files/report/RP026010/RP0260-10-3.PDF.

Alesina, A., La Ferrara, E., 2002. Who trusts others? Journal of Public Economics, 85 (2), pp. 207-234.

Arrow, K. J., 1972. Gifts and exchanges. Philosophy and Public Affairs, pp. 343-362.

Barkmann, J., Burkard, G., Faust, H., Fremerey, M., Koch, S., Lanini, A. 2010. Land tenure rights, village institutions, and rainforest conversion in Central Sulawesi (Indonesia). In: Tscharntke, T., Leuschner, C., Veldkamp, E., Faust, H., Guhardja, E., Bidin, A. (Eds.), Tropical Rainforests and Agroforests under Global Change. Springer, Berlin, pp. 141-160.

Barlow, C., Zen, Z., Gondowarsito, R., 2003. The Indonesian oil palm industry. Oil Palm Industry Economic Journal, 3(1), pp. 8-15.

Barnes, A.D., Jochum, M., Mumme, S., Haneda, N.F., Farajallah, A., Widarto, T.H., Brose, U., 2014. Consequences of tropical land use for multitrophic biodiversity and ecosystem functioning. Nature Communications 5. 
Bengtsson, M., Berggren, N., Jordahl, H., 2005. Trust and Growth in the 1990s-A Robustness Analysis. Working Paper No. 1, Department of Economics, Uppsala University.

Berg, J., Dickhaut, J., McCabe, K., 1995. Trust, reciprocity, and social history. Games and Economic Behavior, 10 (1), pp. 122-142.

Berggren, N., Jordahl, H., 2006. Free to trust: Economic freedom and social capital. Kyklos, 59 (2), pp. 141-169.

Beugelsdijk, S., van Schaik, T., 2005. Social capital and growth in European regions: an empirical test. European Journal of Political Economy, 21 (2), pp. 301-324.

Borras Jr, S., Franco, J., 2010. From Threat to Opportunity-Problems with the Idea of a Code of Conduct for Land-Grabbing. Yale Human Rights and Development Law Journal, 1, pp. 507-524.

Bowles, S., 1998. Endogenous preferences: The cultural consequences of markets and other economic institutions. Journal of Economic Literature, pp. 75-111.

BPS, 2012. Badan Pusat Statistik. Statistical Office of Jambi Province. http://jambi.bps.go.id/index.php?option=com_content\&view=article\&id =164:jambi-dalam-angka-2011\&catid=5:publikasi-buku\&Itemid=30. Retrieved 08.01.2014.

Buchan, N. R., Croson, R. T., Solnick, S., 2008. Trust and gender: An examination of behavior and beliefs in the Investment Game. Journal of Economic Behavior and Organization, 68 (3), pp. 466-476.

Budidarsono, S., Susanti, A., Zoomers, A., 2013. Oil palm plantations in Indonesia: The implications for migration, settlement/resettlement and local economic development. In: Zhen Fang (Ed.): Biofuels - Economy, Environment and Sustainability: Intech. Open Access. 
Cahyadi, E. R., Waibel, H., 2013. Is contract farming in the Indonesian oil palm industry pro-poor?. Journal of Southeast Asian Economies, 30 (1), pp. 62-76.

Cameron, A. C., Trivedi, P. K., 2009. Microeconometrics Using Stata. Stata Press, College Station.

Cardenas, J. C., Carpenter, J., 2008. Behavioural development economics: lessons from field labs in the developing world. The Journal of Development Studies, 44 (3), pp. 311-338.

Carlson, K.M., Curran, L.M., Ratnasari, D., Pittman, A.M., Soares-Filho, B.S., Asner, G.P., 2012. Committed carbon emissions, deforestation, and community land conversion from oil palm plantation expansion in West Kalimantan, Indonesia. Proceedings of the National Academy of Sciences 109 (19), pp. 7559-7564.

Carlson, K. M., Curran, L. M., Asner, G. P., Pittman, A. M., Trigg, S. N., Adeney, J. M., 2013. Carbon emissions from forest conversion by Kalimantan oil palm plantations. Nature Climate Change, 3 (3), pp. 283-287

Carrasco, L. R., Larrosa, C., Milner-Gulland, E. J., Edwards, D. P., 2014. A doubleedged sword for tropical forests. Science, 346 (6205), pp. 38-40.

Carter, C., Finley, W., Fry, J., Jackson, D., Willis, L., 2007. Palm oil markets and future supply. European Journal of Lipid Science and Technology, 109 (4), pp. 307-314.

Casson, A., 2000. The hesitant boom: Indonesia's oil palm sub-sector in an era of economic crisis and political change. Bogor: Center for International Forestry Research. No. 29.

Caviglia-Harris, J. L., Harris, D. W., 2008. Integrating survey and remote sensing data to analyze land use at a fine scale: insights from agricultural households in the Brazilian Amazon. International regional science review, 31 (2), pp. 115-137. 
Colchester, M., Jiwan, N., Andiko, S.M., Firdaus, A.Y., Surambo, A., Pane, H., 2006. Promised Land: palm oil and land acquisition in Indonesia: implications for local communities and indigenous peoples. In: Forest Peoples Programme, Sawit Watch, HuMa and ICRAF. ISBN: 979-15188-0-7.

Corley, R. H. V., 2009. How much palm oil do we need? Environmental Science \& Policy, 12 (2), pp. 134-139.

Croson, R., Buchan, N., 1999. Gender and culture: International experimental evidence from trust games. American Economic Review, pp. 386-391.

Curran, L.M., Trigg, S.N., McDonald, A.K., Astiani, D., Hardiono, Y.M., Siregar, P., 2004. Lowland forest loss in protected areas of Indonesian Borneo. Science 303, pp. 1000-1003.

DeFries, R. S., Houghton, R. A., Hansen, M. C., Field, C. B., Skole, D., Townshend, J., 2002. Carbon emissions from tropical deforestation and regrowth based on satellite observations for the 1980s and 1990s. Proceedings of the National Academy of Sciences, 99 (22), pp. 14256-14261.

DeFries, R.S., Rudel, T., Uriarte, M., Hansen, M., 2010. Deforestation driven by urban population growth and agricultural trade in the twenty-first century. Nature Geoscience 3 (3), pp. 178-181.

De Jong, W., van Noordwijk, M., Sirait, M., Liswanti, N., 2001. FARMING SECONDARY FORESTS IN INDONESIA. Journal of Tropical Forest Science, 13(4), pp. 705-726.

Den Butter, F. A., Mosch, R. H., 2003. Trade, trust and transaction cost. Tinbergen Institute Discussion Paper No. 03-082/3, Vrije Universiteit, Amsterdam.

Dennis, R. A., Mayer, J., Applegate, G., Chokkalingam, U., Colfer, C. J. P., Kurniawan, I., Lachowski, H., Maus, P., Permana, R. P., Ruchiat, Y., Stolle, F., Suyanto, 
Tomich, T. P., 2005. Fire, people and pixels: linking social science and remote sensing to understand underlying causes and impacts of fires in Indonesia. Human Ecology, 33 (4), pp. 465-504.

De Souza Soler, L., Verburg, P. H., 2010. Combining remote sensing and household level data for regional scale analysis of land cover change in the Brazilian Amazon. Regional Environmental Change, 10 (4), pp. 371-386.

Dewi, S., van Noordwijk, M., Ekadinata, A., Pfund, J.L., 2013. Protected areas within multifunctional landscapes: squeezing out intermediate land use intensities in the tropics? Land Use Policy 39 (1), pp. 38-56.

Dollar, D., Kraay, A., 2002. Spreading the wealth. Foreign Affairs, pp. 120-133.

Elmhirst, R., 1999. Space, identity politics and resource control in Indonesia's transmigration programme. Political Geography 18 (7), pp. 813-835.

Fafchamps, M., Minten, B., 2001. Property Rights in a Flea Market Economy. Economic Development and Cultural Change, 49 (2), pp. 229-267.

FAO, 2014. The State of Food and Agriculture. Innovation in Family Farming. Food and Agricultural Organization of the United Nations, Rome. http://www.fao.org/3/ai4040e.pdf.

FAOSTAT, 2014. FAOSTAT Production Statistics. Food and Agricultural Organization of the United Nations, Rome.

Faust, H., Schwarze, S., Beckert, B., Brümmer, B., Dittrich, C., Euler, M., Gatto, M., Hauser-Schäublin, B., Hein, J., Holtkamp, A. M., Ibanez, M., Klasen, S., Kopp, T., Krishna, V., Kunz, Y., Lay, J., Mußhoff, O., Qaim, M., Steinebach, S., Vorlaufer, M., Wollni, M., 2013. Assessment of socio-economic functions of tropical lowland transformation systems in Indonesia: sampling framework and methodological approach. EFForTS Discussion Paper. University of Göttingen. ISSN: 2197-6244. 
Fearnside, P.M., 1997. Transmigration in Indonesia: lessons from its environmental and social impacts. Environmental Management 21 (4), pp. 553-570.

Feder, G., Nishio, A., 1998. The benefits of land registration and titling: economic and social perspectives. Land Use Policy 15 (1), pp. 25-43.

Feintrenie , L., Levang, P., 2009. Sumatra's rubber agroforests: advent, rise and fall of a sustainable cropping system. Small Scale Forestry 8 (3), pp. 323-225.

Feintrenie, L., Schwarze, S., Levang, P., 2010a. Are local people conservationists? Analysis of transition dynamics from agroforests to monoculture plantations in Indonesia. Ecology and Society 15 (4), pp. 37.

Feintrenie, L., Chong, W. K., Levang, P., 2010b. Why do farmers prefer oil palm? Lessons learnt from Bungo District, Indonesia. Small-Scale Forestry 3, pp. 379396.

Fischer, J. A., 2008. Is competition good for trust? Cross-country evidence using microdata. Economics Letters, 100 (1), pp. 56-59.

Fitzherbert, E. B., Struebig, M. J., Morel, A., Danielsen, F., Brühl, C. A., Donald, P. F., Phalan, B., 2008. How will oil palm expansion affect biodiversity? Trends in Ecology \& Evolution 23 (10), pp. 538-545.

Gatto, M., Wollni, M., Qaim, M., 2014. Oil Palm Boom and Land-Use Dynamics in Indonesia: The Role of Policies and Socioeconomic Factors. EFForTS Discussion Paper.University of Göttingen. ISSN: 2197-6244.

Glaeser, E. L., Laibson, D. I., Scheinkman, J. A., Soutter, C. L., 2000. Measuring trust. Quarterly Journal of Economics, 811-846.

Gaveau, D. L., Wich, S., Epting, J., Juhn, D., Kanninen, M., Leader-Williams, N., 2009. The future of forests and orangutans (Pongo abelii) in Sumatra: predicting impacts 
of oil palm plantations, road construction, and mechanisms for reducing carbon emissions from deforestation. Environmental Research Letters, 4 (3), 034013.

Govereh, J., Jayne, T. S., 2003. Cash cropping and food crop productivity: synergies or trade-offs? Agricultural Economics, 28 (1), pp. 39-50.

Greene, W.H., 2008. Econometric Analysis. Pearson Prentice Hall, New Jersey.

Hansen, M. C., Stehman, S. V., Potapov, P. V., Arunarwati, B., Stolle, F., Pittman, K., 2009. Quantifying changes in the rates of forest clearing in Indonesia from 1990 to 2005 using remotely sensed data sets. Environmental Research Letters, 4(3), 34001 .

Hansen, M. C., Stehman, S. V., Potapov, P. V., 2010. Quantification of global gross forest cover loss. Proceedings of the National Academy of Sciences, 107 (19), pp. 8650-8655.

Hansen, M. C., Potapov, P. V., Moore, R., Hancher, M., Turubanova, S. A., Tyukavina, A.,Thau, D., Stehman, S. V., Goetz, S. J., Loveland, T.R., Kommareddy, A., Egorov, A., Chini, L., Justice, C. O., and Townshend, J. R. G., 2013. Highresolution global maps of 21st-century forest cover change. Science, 342 (6160), pp. 850-853.

Henrich, J., Boyd, R., Bowles, S., Camerer, C., Fehr, E., Gintis, H., McElreath, R., 2001. In search of homo economicus: behavioral experiments in 15 small-scale societies. American Economic Review, pp. 73-78.

Henrich, J., Ensminger, J., McElreath, R., Barr, A., Barrett, C., Bolyanatz, A., Cardenas, J.C., Gurven, M., Gwako, E., Henrich, N., Lesorogol, C., Marlowe, F., Tracer, D. Ziker, J., 2010. Markets, religion, community size, and the evolution of fairness and punishment. Science, 327 (5972), pp. 1480-1484. 
Herath, D., Weersink, A., 2009. From plantations to smallholder production: the role of policy in the reorganization of the sri lankan tea sector. World Development, 37(11), pp. 1759-1772.

Kirby, K. R., Laurance, W. F., Albernaz, A. K., Schroth, G., Fearnside, P. M., Bergen, S., 2006. The future of deforestation in the Brazilian Amazon. Futures of Bioregions 38 (4), pp. 432-453.

Knack, S., Keefer, P., 1997. Does social capital have an economic payoff? A crosscountry investigation. The Quarterly Journal of Economics, pp. 1251-1288.

Koh, L. P., Miettinen, J., Liew, S. C., Ghazoul, J., 2011. Remotely sensed evidence of tropical peatland conversion to oil palm. Proceedings of the National Academy of Sciences 108 (12), pp. 5127-5132.

Koh, L. P., Wilcove, D. S., 2008. Is oil palm agriculture really destroying tropical biodiversity? Conservation Letters, 1(2), pp. 60-64.

Krishna, V.V., Pascual U., Qaim, M., 2014. Do emerging land markets promote forestland appropriation? Evidence from Indoensia. EFForTS Discussion Paper Series No. 7, Goettingen: Georg-August University of Goettingen, Germany. ISSN: 2197-6244.

Lambin, E. F., Geist, H. J., Lepers, E., 2003. Dynamics of land-use and land-cover change in tropical regions. Annual Review of Environment and Resources, 28(1), pp. 205-241.

Larson, D. F., 1996. Indonesia's palm oil subsector (No. 1654). The World Bank.

Levang, P., 1997. La terre d'en face: la transmigration en Indonésie. Editions de l'ORSTOM, Montpellier.

Lyons, B., Mehta, J., 1997. Contracts, opportunism and trust: self-interest and social orientation. Cambridge Journal of Economics, 21 (2), pp. 239-257. 
Margono, B. A., Potapov, P. V., Turubanova, S., Stolle, F., Hansen, M. C., 2014. Primary forest cover loss in Indonesia over 2000-2012. Nature Climate Change.

Margono, B. A., Turubanova, S., Zhuravleva, I., Potapov, P., Tyukavina, A., Baccini, A., Goetz, S., Hansen, M. C., 2012. Mapping and monitoring deforestation and forest degradation in Sumatra (Indonesia) using Landsat time series data sets from 1990 to 2010. Environmental Research Letters, 7 (3), 034010.

Marti, S., 2008. Losing Ground. The human rights impacts of oil palm plantation expansion in Indonesia. Friends of the Earth, LifeMosaic, Sawit Watch. http://www.foe.co.uk/sites/default/files/downloads/losingground.pdf.

McCarthy, J. F., Cramb, R. A, 2009. Policy narratives, landholder engagement, and oil palm expansion on the Malaysian and Indonesian frontiers. The Geographical Journal, 175(2), pp. 112-123.

McCarthy, J. F., 2010. Processes of inclusion and adverse incorporation: oil palm and agrarian change in Sumatra, Indonesia. The Journal of Peasant Studies, 37(4), pp. 821-850.

McCarthy, J. F., Gillespie, P., Zen, Z., 2012. Swimming upstream: local Indonesian production networks in "globalized" palm oil production. World Development, 40(3), pp. 555-569.

Meijerink, G., Bulte, E., Alemu, D., 2014. Formal institutions and social capital in value chains: The case of the Ethiopian Commodity Exchange. Food Policy, 49, pp. 1-12.

Mena, C.F., Bilsborrow, R.E., McClain, M.E., 2006. Socioeconomic drivers of deforestation in the northern Ecuadorian Amazon. Environmental Management 37 (6), pp. 802-815.

Mertens, B., Sunderlin, W. D., Ndoye, O., Lambin, E.F., 2000. Impact of macroeconomic change on deforestation in South Cameroon: integration of 
household survey and remotely-sensed data. World Development 28 (6), pp. 983999.

Ministry of Agriculture, 2014. Badan Pusat Statistik. Central Statistical Office of Indonesian Ministry of Agriculture. http://dds2.bps.go.id/eng/.

Mitsuda, Y., Ito, S., 2011. A review of spatial-explicit factors determining spatial distribution of land use/land-use change. Landscape and Ecological Engineering, 7 (1), pp. 117-125.

Muller, D., Zeller, M., 2002. Land use dynamics in the central highlands of Vietnam: a spatial model combining village survey data with satellite imagery interpretation. Agricultural Economics 27 (3), pp. 333-354.

Murdiyarso, D., Noordwijk, M. V., Wasrin, U. R., Tomich, T. P., Gillison, A. N., 2002. Environmental benefits and sustainable land-use options in the Jambi transect, Sumatra. Journal of Vegetation Science, 13 (3), pp. 429-438.

Narayan, D., Pritchett, L., 1999. Cents and sociability: Household income and social capital in rural Tanzania. Economic Development and Cultural Change, 47 (4), pp. 871-897.

Nelson, P.N., Gabriel, J., Filer, C., Banabas, M., Sayer, J.A., Curry, G.N., 2013. Oil palm and deforestation in Papua New Guinea. Conservation Letters.

Nesheim., I., Reidsma, P., Bezlepkina, I., Verburg., R., Abdeladhim, M.A., Bursztyn, M., Chen, L., Cisse, Y., Feng, S.Y., Gicheru, P., Konig, H.J., Novira, N., Purushothaman, S., Rodrigues, S., Sghaier, M., 2014. Causal chains, policy tradeoffs and sustainability: analysing land (mis)use in seven countries in the South. Land Use Policy 37, pp. 60-70. 
Obidzinski, K., Takahashi, I., Dermawan, A., Komarudin, H., Adrianto, A., 2013. Can large scale land acquisition for agro-development in Indonesia be managed sustainably? Land Use Policy 30, pp. 952-965.

Otsuka, K., Suyanto, S., Sonobe, T., Tomich, T. P., 2001. Evolution of land tenure institutions and development of agroforestry: evidence from customary land areas of Sumatra. Agricultural Economics 25 (1), pp. 85-101.

Putnam, R. D., Leonardi, R., Nanetti, R. Y., 1993. Making democracy work: civic traditions in modern Italy. Princeton: Princeton University Press.

Ravallion, M., 2001. Growth, inequality and poverty: looking beyond averages. World development, 29 (11), pp. 1803-1815.

Rist, L., Feintrenie, L., Levang, P., 2010. The livelihood impacts of oil palm: smallholders in Indonesia. Biodiversity and Conservation, 19 (4), pp. 1009-1024.

Rosyani, 2011. The impact of activities pattern partnership company oil palm plantations against sustainability villagers surrounding. Prosiding of Nasional Seminar Volume II, Sumatera Indonesia.

Sahn, D. E., Stifel, D., 2003. Exploring alternative measures of welfare in the absence of expenditure data. Review of Income and Wealth, 49 (4), pp. 463-489.

Sheil, D., Casson, A., Meijaard, E., van Noordwijk, M., Gaskell, J., Sunderland-Groves, J., Wertz, K., Kanninen, M., 2009. The impacts and opportunities of oil palm in Southeast Asia: What do we know and what do we need to know? Occasional paper no. 51. CIFOR, Bogor, Indonesia. ISBN 978-979-1412-74-2

Sirait. M.T., 2009. Indigenous Peoples and Oil Palm Plantations Expansion in West Kalimantan, Indonesia. Occasional Paper. University of Amsterdam. Cordaid. 
Siziba, S., Bulte, E., 2012. Does market participation promote generalized trust? Experimental evidence from Southern Africa. Economics Letters, 117 (1), pp. 156160.

Swinnen, J. F., Maertens, M., 2007. Globalization, privatization, and vertical coordination in food value chains in developing and transition countries. Agricultural Economics, 37 (1), pp 89-102.

Susila, W. R., 2004. Contribution of oil palm industry to economic growth and poverty alleviation in Indonesia. Jurnal Litbang Pertanian, 23 (3), pp. 107-114.

Thorburn, C. C., 2004. The plot thickens: land administration and policy in post-New Order Indonesia. Asia Pacific Viewpoint 45 (1), pp. 33-49.

Tu, Q., Bulte, E., 2010. Trust, market participation and economic outcomes: evidence from rural China. World Development, 38 (8), pp. 1179-1190.

Villamor, G. B., Desrianti, F., Akiefnawati, R., Amaruzaman, S., van Noordwijk, M., 2013. Gender influences decisions to change land use practices in the tropical forest margins of Jambi, Indonesia. Mitigation and Adaptation Strategies for Global Change 19, pp. 1-23.

Villamor, G.B., Pontius, R., Gilmore, Jr., Noordwijk, M., 2014. Agroforest's growing role in reducing carbon losses from Jambi (Sumatra), Indonesia. Regional Environmental Change 14 (2), pp. 825-834.

Wakker, E., 2005. Greasy palms. The social and ecological impacts of large-scale oil palm plantation development in Southeast Asia. Friends of the Earth.

Wheeler, D., Hammer, D., Kraft, R., Dasgupta, S., Blankespoor, B., 2013. Economic dynamics and forest clearing: a spatial econometric analysis for Indonesia. New Climate Economics 85, pp. 85-96. 
Wich, S. A., Garcia-Ulloa, J., Kühl, H. S., Humle, T., Lee, J. S., Koh, L. P., 2014. Will Oil Palm's Homecoming Spell Doom for Africa's Great Apes? Current Biology, 24 (14), pp. 1659-1663.

Wicke, B., Sikkema, R., Dornburg, V., Faaij, A., 2011. Exploring land use changes and the role of palm oil production in Indonesia and Malaysia. Land Use Policy 28 (1), pp. 193-206.

Wilcove, D.S., Koh, L.P., 2010. Addressing the threats to biodiversity from oil-palm agriculture. Biodiversity Conservation 19 (4), pp. 999-1007.

Wilcove, D. S., Giam, X., Edwards, D. P., Fisher, B., Koh, L. P., 2013. Navjot's nightmare revisited: logging, agriculture, and biodiversity in Southeast Asia. Trends in Ecology \& Evolution, 28 (9), pp. 531-540.

Woolthuis, R. K., Hillebrand, B., Nooteboom, B., 2005. Trust, contract and relationship development. Organization Studies, 26 (6), pp. 813-840.

World Bank, 1981. Accelerated Development in Sub-Saharan Africa.World Bank: Washington, DC.

World Bank, 2011. Rising Global Interest in Farmland. Can it yield sustainale and equitable benefits? World Bank: Washington, DC.

Zen, Z., C. Barlow and R. Gondowarsito., 2005. Oil palm in Indonesian socio-economic improvement: a review of options. Working Papers in Trade and Development. Canberra: Research School of Pacific and Asian Studies, ANU. 


\section{Appendix A: Additional tables}


Table A1. Land-use equations (SUR model) with rubber plantations and rubber agroforests as two separate explanatory variables

\begin{tabular}{|c|c|c|c|}
\hline & $\begin{array}{c}\text { (1) } \\
\text { Oil palm }\end{array}$ & $\begin{array}{c}(2) \\
\text { Rubber }\end{array}$ & $\begin{array}{c}\text { (3) } \\
\text { Forest }\end{array}$ \\
\hline Year 2012 (dummy) & $\begin{array}{l}527.67 * * * \\
(85.47)\end{array}$ & $\begin{array}{l}15.98 \\
(109.75)\end{array}$ & $\begin{array}{l}-250.57 \\
(162.95)\end{array}$ \\
\hline \multicolumn{4}{|l|}{ Land-use variables } \\
\hline Oil palm ${ }_{t-10}$ & $\begin{array}{l}0.264 * * * \\
(0.097)\end{array}$ & $\begin{array}{l}0.008 \\
(0.116)\end{array}$ & $\begin{array}{l}-0.746 * * * \\
(0.176)\end{array}$ \\
\hline Rubber plantation $_{\mathrm{t}-10}$ & $\begin{array}{l}0.198 * * * \\
(0.057)\end{array}$ & $\begin{array}{l}0.344 * * * \\
(0.082)\end{array}$ & \\
\hline Rubber agroforest $t_{\mathrm{t}-10}$ & $\begin{array}{l}0.305^{* * * *} \\
(0.101)\end{array}$ & $\begin{array}{l}0.487 * * * \\
(0.149)\end{array}$ & \\
\hline Forest $_{\mathrm{t}-10}$ & $\begin{array}{l}0.005 \\
(0.033)\end{array}$ & & $\begin{array}{l}0.084 \\
(0.061)\end{array}$ \\
\hline Fallow $_{\mathrm{t}-10}$ & $\begin{array}{l}0.304 * * * \\
(0.078)\end{array}$ & $\begin{array}{l}-0.265^{* * *} \\
(0.099)\end{array}$ & $\begin{array}{l}-0.693 * * * \\
(0.146)\end{array}$ \\
\hline Total land ${ }_{t}{ }^{a}$ & $\begin{array}{l}-0.046 \\
(0.036)\end{array}$ & $\begin{array}{l}0.266 * * * \\
(0.046)\end{array}$ & $\begin{array}{l}0.304 * * * \\
(0.071)\end{array}$ \\
\hline \multicolumn{4}{|l|}{ Socioeconomic variables } \\
\hline Old village (dummy) & $\begin{array}{l}-225.02 \\
(288.73)\end{array}$ & $\begin{array}{l}328.69 \\
(371.99)\end{array}$ & $\begin{array}{l}38.38 \\
(544.39)\end{array}$ \\
\hline Population density $\mathrm{t}_{\mathrm{t}-10}$ (pop/ha) & $\begin{array}{l}-240.57 * * \\
(118.17)\end{array}$ & $\begin{array}{l}-97.33 \\
(151.86)\end{array}$ & $\begin{array}{l}284.48 \\
(224.69)\end{array}$ \\
\hline Distance to $\operatorname{road}_{\mathrm{t}-10}(\mathrm{~km})$ & $\begin{array}{l}10.92 * * \\
(4.831)\end{array}$ & $\begin{array}{l}-6.203 \\
(6.169)\end{array}$ & $\begin{array}{l}38.41 * * * \\
(9.332)\end{array}$ \\
\hline Chemical fertilizer $_{\mathrm{t}-10}$ (share of $\left.\mathrm{HH}\right)$ & $\begin{array}{l}-98.17 \\
(144.36)\end{array}$ & $\begin{array}{l}-233.92 \\
(184.94)\end{array}$ & $\begin{array}{l}-279.09 \\
(277.29)\end{array}$ \\
\hline Wealth index $\mathrm{t}_{\mathrm{t}-10}$ & $\begin{array}{l}-485.95 * * * \\
(195.43)\end{array}$ & $\begin{array}{l}471.64 * \\
(250.02)\end{array}$ & $\begin{array}{l}-23.72 \\
(376.64)\end{array}$ \\
\hline Land title $\mathrm{t}_{\mathrm{t}-10}$ (share of $\left.\mathrm{HH}\right)$ & $\begin{array}{l}121.59 \\
(132.49)\end{array}$ & $\begin{array}{l}-86.59 \\
(165.82)\end{array}$ & $\begin{array}{l}87.72 \\
(255.39)\end{array}$ \\
\hline Dominant ethnicity $_{\mathrm{t}-10}$ (share of $\left.\mathrm{HH}\right)$ & $\begin{array}{l}208.95 \\
(237.81)\end{array}$ & $\begin{array}{l}659.92 * * \\
(304.48)\end{array}$ & $\begin{array}{l}537.61 \\
(446.87)\end{array}$ \\
\hline Constant & $\begin{array}{l}-714.32 * * * \\
(281.83)\end{array}$ & $\begin{array}{l}-1023 * * * \\
(374.97)\end{array}$ & $\begin{array}{l}358.24 \\
(431.89)\end{array}$ \\
\hline Village fixed effects & YES & YES & YES \\
\hline Observations & 180 & 180 & 180 \\
\hline $\begin{array}{l}\mathrm{R}^{2} \\
\text { Breusch-Pagan independence test }\left(\mathrm{chi}^{2}\right)\end{array}$ & 0.87 & $\begin{array}{c}0.99 \\
52.37 * * *\end{array}$ & 0.91 \\
\hline
\end{tabular}

Notes: Estimation coefficients are shown with standard errors in parentheses. All land-use variables are expressed in ha. $\mathrm{HH}$, households. *** Significant at the $1 \%$ level. ** Significant at the $5 \%$ level. * Significant at the $10 \%$ level. ${ }^{\text {a }}$ Total land comprises the total village area, including oil palm, rubber, forest, and fallow land, as well as residential areas and food crops such as paddy, fruits, and vegetables. 
Table A2. Land-use equations (SUR model) with contract dummy included

\begin{tabular}{|c|c|c|c|}
\hline & $\begin{array}{c}(1) \\
\text { Oil palm }\end{array}$ & $\begin{array}{c}(2) \\
\text { Rubber }\end{array}$ & $\begin{array}{l}(3) \\
\text { Forest }\end{array}$ \\
\hline Year 2012 (dummy) & $\begin{array}{l}474.27 * * * \\
(84.41)\end{array}$ & $\begin{array}{l}-3.961 \\
(112.61)\end{array}$ & $\begin{array}{l}-222.09 \\
(163.57)\end{array}$ \\
\hline \multicolumn{4}{|l|}{ Land-use variables } \\
\hline Oil palm $\mathrm{t}_{\mathrm{t} 10}$ & $\begin{array}{l}0.162 * \\
(0.098)\end{array}$ & $\begin{array}{l}-0.014 \\
(0.121)\end{array}$ & $\begin{array}{l}-0.671 * * * \\
(0.183)\end{array}$ \\
\hline Rubber $_{\mathrm{t}-10}$ & $\begin{array}{l}0.286 * * * \\
(0.073)\end{array}$ & $\begin{array}{l}0.459 * * * \\
(0.109)\end{array}$ & \\
\hline Forest $_{\mathrm{t}-10}$ & $\begin{array}{l}-0.006 \\
(0.032)\end{array}$ & & $\begin{array}{l}0.091 \\
(0.061)\end{array}$ \\
\hline Fallow $_{t-10}$ & $\begin{array}{l}0.362 * * * \\
(0.079)\end{array}$ & $\begin{array}{l}-0.196^{*} \\
(0.105)\end{array}$ & $\begin{array}{l}-0.702 * * * \\
(0.145)\end{array}$ \\
\hline Total land ${ }_{t}{ }^{a}$ & $\begin{array}{l}-0.051 \\
(0.036)\end{array}$ & $\begin{array}{l}0.255 * * * \\
(0.047)\end{array}$ & $\begin{array}{l}0.302 * * * \\
(0.071)\end{array}$ \\
\hline \multicolumn{4}{|l|}{ Socioeconomic variables } \\
\hline Old village (dummy) & $\begin{array}{l}-698.29 * * * \\
(278.65)\end{array}$ & $\begin{array}{l}-264.91 \\
(370.34)\end{array}$ & $\begin{array}{l}125.39 \\
(545.78)\end{array}$ \\
\hline Population density $\mathrm{t}_{\mathrm{t}-10}(\mathrm{pop} / \mathrm{ha})$ & $\begin{array}{l}-263.75^{* *} \\
(118.16)\end{array}$ & $\begin{array}{l}-46.97 \\
(157.99)\end{array}$ & $\begin{array}{l}334.42 \\
(226.81)\end{array}$ \\
\hline Distance to $\operatorname{road}_{\mathrm{t}-10}(\mathrm{~km})$ & $\begin{array}{l}14.01 * * * \\
(4.847)\end{array}$ & $\begin{array}{l}-7.335 \\
(6.417)\end{array}$ & $\begin{array}{l}35.39 * * * \\
(9.561)\end{array}$ \\
\hline Chemical fertilizer $\mathrm{t}_{\mathrm{t}-10}$ (share of $\left.\mathrm{HH}\right)$ & $\begin{array}{l}-4.261 \\
(142.25)\end{array}$ & $\begin{array}{l}-176.54 \\
(189.43)\end{array}$ & $\begin{array}{l}-321.22 \\
(277.78)\end{array}$ \\
\hline Wealth index $\mathrm{t}_{-10}$ & $\begin{array}{l}-519.16^{* * * *} \\
(191.23)\end{array}$ & $\begin{array}{l}356.07 \\
(253.84)\end{array}$ & $\begin{array}{l}-57.55 \\
(375.71)\end{array}$ \\
\hline Land title $_{\mathrm{t}-10}($ share of $\mathrm{HH})$ & $\begin{array}{l}120.53 \\
(131.47)\end{array}$ & $\begin{array}{l}6.365 \\
(169.87)\end{array}$ & $\begin{array}{l}134.57 \\
(256.57)\end{array}$ \\
\hline Dominant ethnicity $_{\mathrm{t}-10}$ (share of $\left.\mathrm{HH}\right)$ & $\begin{array}{l}-233.03 \\
(232.94)\end{array}$ & $\begin{array}{l}-54.96 \\
(300.43)\end{array}$ & $\begin{array}{l}544.11 \\
(444.76)\end{array}$ \\
\hline NES contract (dummy) & $\begin{array}{l}290.63^{* * * *} \\
(100.36)\end{array}$ & $\begin{array}{l}-49.67 \\
(132.76)\end{array}$ & $\begin{array}{l}-260.52 \\
(197.29)\end{array}$ \\
\hline Constant & $\begin{array}{l}20.04 \\
(218.89)\end{array}$ & $\begin{array}{l}102.68 \\
(290.09)\end{array}$ & $\begin{array}{l}307.26 \\
(431.53)\end{array}$ \\
\hline Village fixed effects & YES & YES & YES \\
\hline Observations & 180 & 180 & 180 \\
\hline $\begin{array}{l}\mathrm{R}^{2} \\
\text { Breusch-Pagan independence test }\left(\mathrm{chi}^{2}\right)\end{array}$ & 0.87 & $\begin{array}{c}0.99 \\
50.51 * * *\end{array}$ & 0.91 \\
\hline
\end{tabular}

Notes: Estimation coefficients are shown with standard errors in parentheses. All land-use variables are expressed in ha. $\mathrm{HH}$, households. *** Significant at the $1 \%$ level. ** Significant at the $5 \%$ level. * Significant at the $10 \%$ level. ${ }^{\text {a }}$ Total land comprises the total village area, including oil palm, rubber, forest, and fallow land, as well as residential areas and food crops such as paddy, fruits, and vegetables. 
Table A3. Land-use equations (SUR model) with share of independent oil palm land included

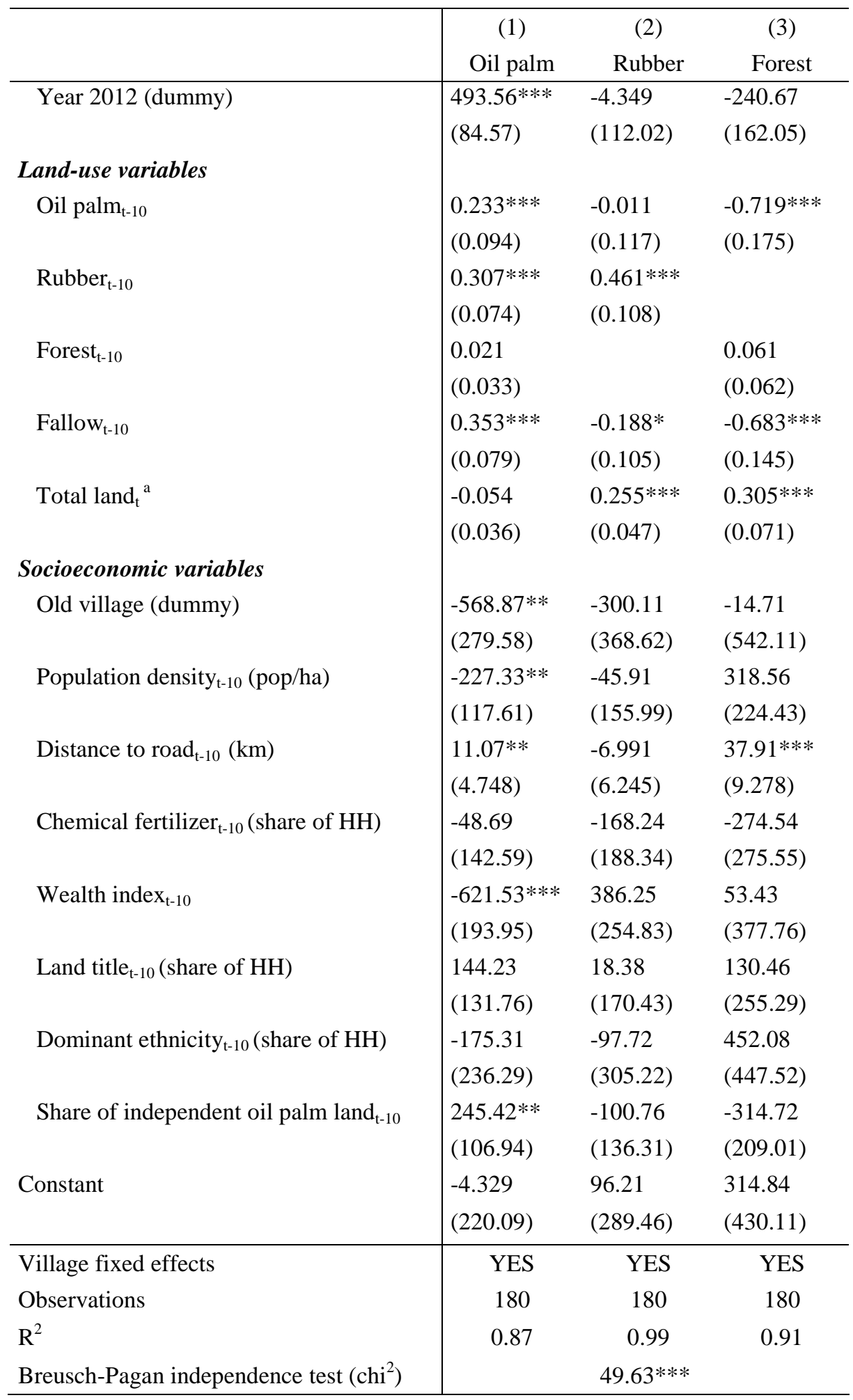

Notes: Estimation coefficients are shown with standard errors in parentheses. All land-use variables are expressed in ha. HH, households. *** Significant at the $1 \%$ level. ** Significant at the $5 \%$ level. * Significant at the $10 \%$ level. ${ }^{\text {a }}$ Total land comprises the total village area, including oil palm, rubber, forest, and fallow land, as well as residential areas and food crops such as paddy, fruits, and vegetables. 
Table A4. Bivariate probit with selection model estimates and marginal effects

\begin{tabular}{|c|c|c|c|c|c|}
\hline \multirow{3}{*}{ Variable } & \multicolumn{5}{|c|}{ Bivariate probit } \\
\hline & $\begin{array}{c}\text { First stage } \\
\text { investor } \\
\text { visit }\end{array}$ & $\begin{array}{l}\text { Investor } \\
\text { visit }\end{array}$ & $\begin{array}{l}\text { Contract } \\
\text { adoption }\end{array}$ & $\begin{array}{l}\text { Investor } \\
\text { visit }\end{array}$ & $\begin{array}{l}\text { Contract } \\
\text { adoption }\end{array}$ \\
\hline & $\mathrm{N}=78$ & $\mathrm{~N}=78$ & $\mathrm{~N}=49$ & $\mathrm{~N}=78$ & $\mathrm{~N}=49$ \\
\hline & \multicolumn{3}{|c|}{ Coefficient } & \multicolumn{2}{|c|}{ Marginal effects } \\
\hline \multirow{3}{*}{ Average land slope } & $(1)$ & $(2)$ & (3) & $(4)$ & $(5)$ \\
\hline & $0.632 * * *$ & $0.632 * * *$ & & $0.234 * * *$ & \\
\hline & $(0.222)$ & $(0.247)$ & & $(0.087)$ & \\
\hline \multirow[t]{2}{*}{ Village land area (ha) (x1000) } & -0.002 & -0.002 & -0.027 & -0.001 & -0.011 \\
\hline & $(0.017)$ & $(0.018)$ & $(0.025)$ & $(0.001)$ & $(0.011)$ \\
\hline \multirow[t]{2}{*}{ Village population $(\mathrm{x} 1000)$} & -0.024 & -0.018 & 0.397 & -0.007 & 0.159 \\
\hline & $(0.253)$ & $(0.204)$ & $(0.268)$ & $(0.081)$ & $(0.111)$ \\
\hline \multirow[t]{2}{*}{ Electricity (dummy) } & -0.181 & -0.173 & -0.805 & -0.064 & $-0.336^{*}$ \\
\hline & $(0.388)$ & $(0.382)$ & $(0.593)$ & $(0.141)$ & $(0.209)$ \\
\hline \multirow[t]{2}{*}{ Distance to all season road $(\mathrm{km})$} & 0.004 & 0.004 & -0.009 & -0.002 & -0.003 \\
\hline & $(0.019)$ & $(0.013)$ & $(0.017)$ & $(0.001)$ & $(0.011)$ \\
\hline \multirow[t]{2}{*}{ Distance to oil palm mill (km) } & $-0.005^{* *}$ & $-0.005^{*}$ & -0.001 & $-0.002 *$ & -0.000 \\
\hline & $(0.002)$ & $(0.003)$ & $(0.003)$ & $(0.001)$ & $(0.000)$ \\
\hline \multirow[t]{2}{*}{ Wealth index } & 0.204 & 0.177 & -0.868 & 0.065 & -0.341 \\
\hline & $(0.761)$ & $(0.819)$ & $(1.133)$ & $(0.303)$ & $(0.463)$ \\
\hline \multirow[t]{2}{*}{ Transmigrant village (dummy) } & 0.296 & 0.284 & 0.539 & 0.101 & 0.221 \\
\hline & $(0.514)$ & $(0.426)$ & $(0.606)$ & $(0.143)$ & $(0.178)$ \\
\hline \multirow[t]{2}{*}{ Government land titles (share of $\mathrm{HH}$ ) } & $1.454 * * *$ & $1.439 * *$ & -0.353 & $0.532 * *$ & -0.056 \\
\hline & $(0.542)$ & $(0.587)$ & $(0.549)$ & $(0.212)$ & $(0.258)$ \\
\hline \multirow[t]{2}{*}{ Constant } & -0.854 & -0.857 & 0.626 & & \\
\hline & $(0.646)$ & $(0.613)$ & $(0.702)$ & & \\
\hline Rho & & $\begin{array}{l}-0.285 \\
(1.003)\end{array}$ & & & \\
\hline Log likelihood & -42.19 & -71.79 & & & \\
\hline \multicolumn{6}{|l|}{ Wald test of independent equations } \\
\hline $\mathrm{Chi}^{2}(1)$ prob. $>\mathrm{chi}^{2}$ & & 0.78 & & & \\
\hline Pseudo $\mathrm{R}^{2}$ & 0.18 & & & & \\
\hline
\end{tabular}




\section{Appendix B1: Village survey questionnaire}


Appendix B

0.1 To be completed by Interviewer

Please complete before the Interview

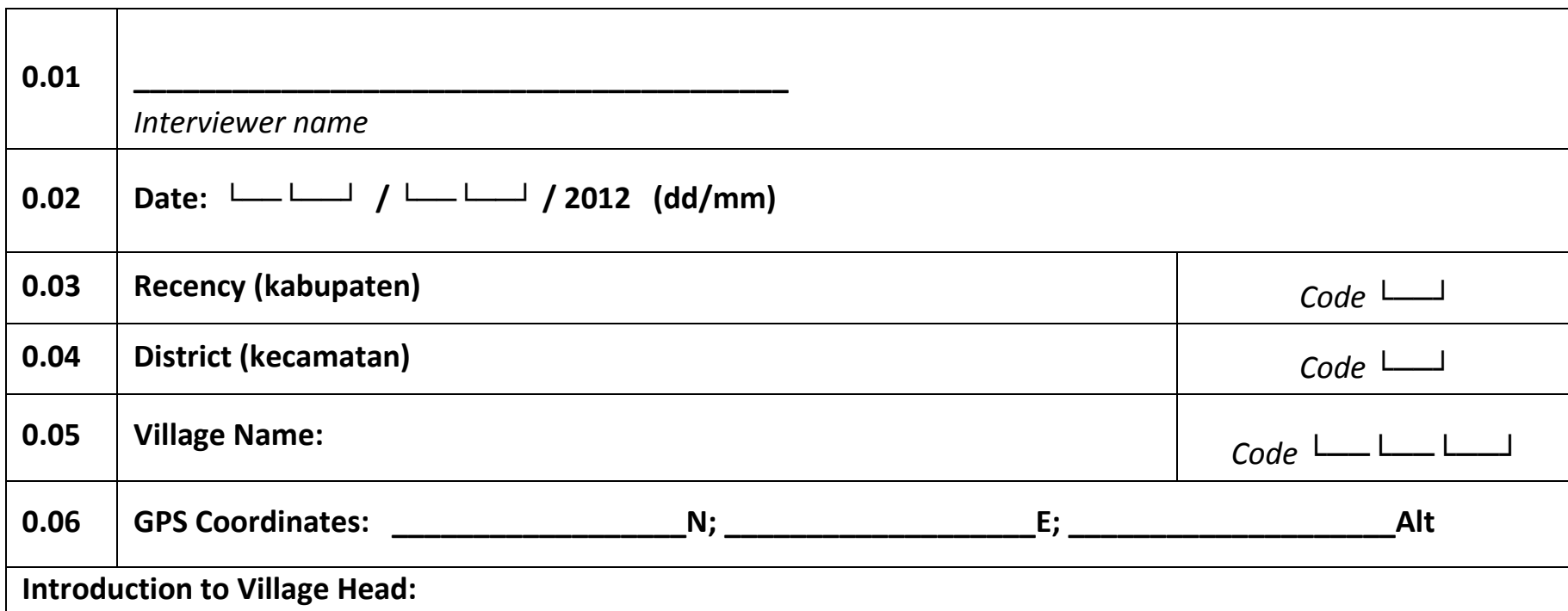

Signature of Interviewers:

Signature of Supervisor

1.

\section{Signature Data Entry}

2.

\begin{tabular}{|l|l|l|}
\hline $\mathbf{0 . 0 7}$ & \multicolumn{2}{|l|}{ How many were not willing to participate? } \\
\hline $\mathbf{0 . 0 8}$ & Why not? & \\
\hline $\mathbf{0 . 0 9}$ & Interview Language & \\
\hline $\mathbf{0 . 1 0}$ & Starting Time & ${ }_{--}:_{--}$(hh:mm) \\
\hline
\end{tabular}

Space for Remarks 


\begin{tabular}{|c|c|c|c|c|c|c|c|c|c|c|c|c|c|}
\hline \multicolumn{14}{|c|}{ 1. Interviewee Information/ Characteristics } \\
\hline & $\mathrm{a}$ & $\mathrm{b}$ & c & $d$ & $\mathrm{e}$ & \multicolumn{2}{|c|}{$f$} & $\mathrm{~g}$ & $\mathrm{~h}$ & $\bar{i}$ & $\bar{j}$ & $\mathrm{k}$ & 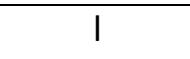 \\
\hline & Name & Age & $\begin{array}{c}\text { Sex } \\
1=\text { male } \\
2=\text { female }\end{array}$ & $\begin{array}{l}\text { Title } \\
\text { (see } \\
\text { codes) }\end{array}$ & $\begin{array}{l}\text { Year of } \\
\text { Election }\end{array}$ & \multicolumn{2}{|c|}{$\begin{array}{l}\text { Years of } \\
\text { Education }\end{array}$} & $\begin{array}{l}\text { House } \\
\text { hold } \\
\text { Size }\end{array}$ & $\begin{array}{l}\text { Religion } \\
\text { (see } \\
\text { codes) }\end{array}$ & $\begin{array}{l}\text { Ethnicity } \\
\text { (see } \\
\text { codes) }\end{array}$ & $\begin{array}{l}\text { Main Source } \\
\text { of Income } \\
\text { (see codes) }\end{array}$ & $\begin{array}{c}\text { Land } \\
\text { Ownership } \\
\text { Palm Oil }\end{array}$ & $\begin{array}{c}\text { Land } \\
\text { Ownership } \\
\text { Rubber }\end{array}$ \\
\hline 1.01 & & & & & & & & & & & & ha & ha \\
\hline 1.02 & & & & & & & & & & & & ha & ha \\
\hline 1.03 & & & & & & & & & & & & ha & ha \\
\hline 1.04 & & & & & & & & & & & & ha & ha \\
\hline 1.05 & & & & & & & & & & & & ha & ha \\
\hline 1.06 & & & & & & & & & & & & ha & ha \\
\hline 1.07 & & & & & & & & & & & & ha & ha \\
\hline 1.08 & & & & & & & & & & & & ha & ha \\
\hline 1.09 & & & & & & & & & & & & ha & ha \\
\hline \multicolumn{4}{|c|}{ Codes for 1.d: Title } & \multicolumn{3}{|c|}{ Codes for 1.h: Religion } & \multicolumn{4}{|c|}{ Codes for 1.i: Ethnicity } & \multicolumn{3}{|c|}{ Codes for 1.j: Main income source } \\
\hline \multicolumn{4}{|c|}{$\begin{array}{l}1=\text { village head/chief } \\
2=\text { chief assistant (vice) } \\
3=\text { sekretaris } \\
4=\text { Dusun Leader } \\
5=\text { RT Leader } \\
6=\text { elders' group leader } \\
7=\text { women's group leader } \\
8=\text { youth leader } \\
9=\text { other }, \text { specify in box }\end{array}$} & \multicolumn{3}{|c|}{$\begin{array}{l}1=\text { Islam } \\
2=\text { Hindu } \\
3=\text { Protestan } \\
4=\text { Katolik } \\
5=\text { Pantekosta } \\
6=\text { Buddha } \\
7=\text { Konghucu } \\
8=\text { other }, \text { specify in box }\end{array}$} & \multicolumn{2}{|c|}{$\begin{array}{l}1 \text { = Minang } \\
2=\text { Melayu Jamb } \\
3=\text { Bugis } \\
4=\text { Jawa } \\
5=\text { Batak } \\
6=\text { Sunda } \\
7=\text { Betawi } \\
8=\text { Banjar }\end{array}$} & \multicolumn{2}{|c|}{$\begin{array}{l}9=\text { Melayu } \\
10=\text { Tionghoa } \\
11=\text { other } \\
\text { specify in box }\end{array}$} & \multicolumn{3}{|c|}{$\begin{array}{l}1 \text { = Agriculture (oil palm, rubber, } \\
\text { livestock, etc.) } \\
2 \text { = Trade/ Commerce (wage laborer, } \\
\text { working for company, etc.) } \\
3 \text { = Government Official } \\
4 \text { = Other, specify }\end{array}$} \\
\hline
\end{tabular}




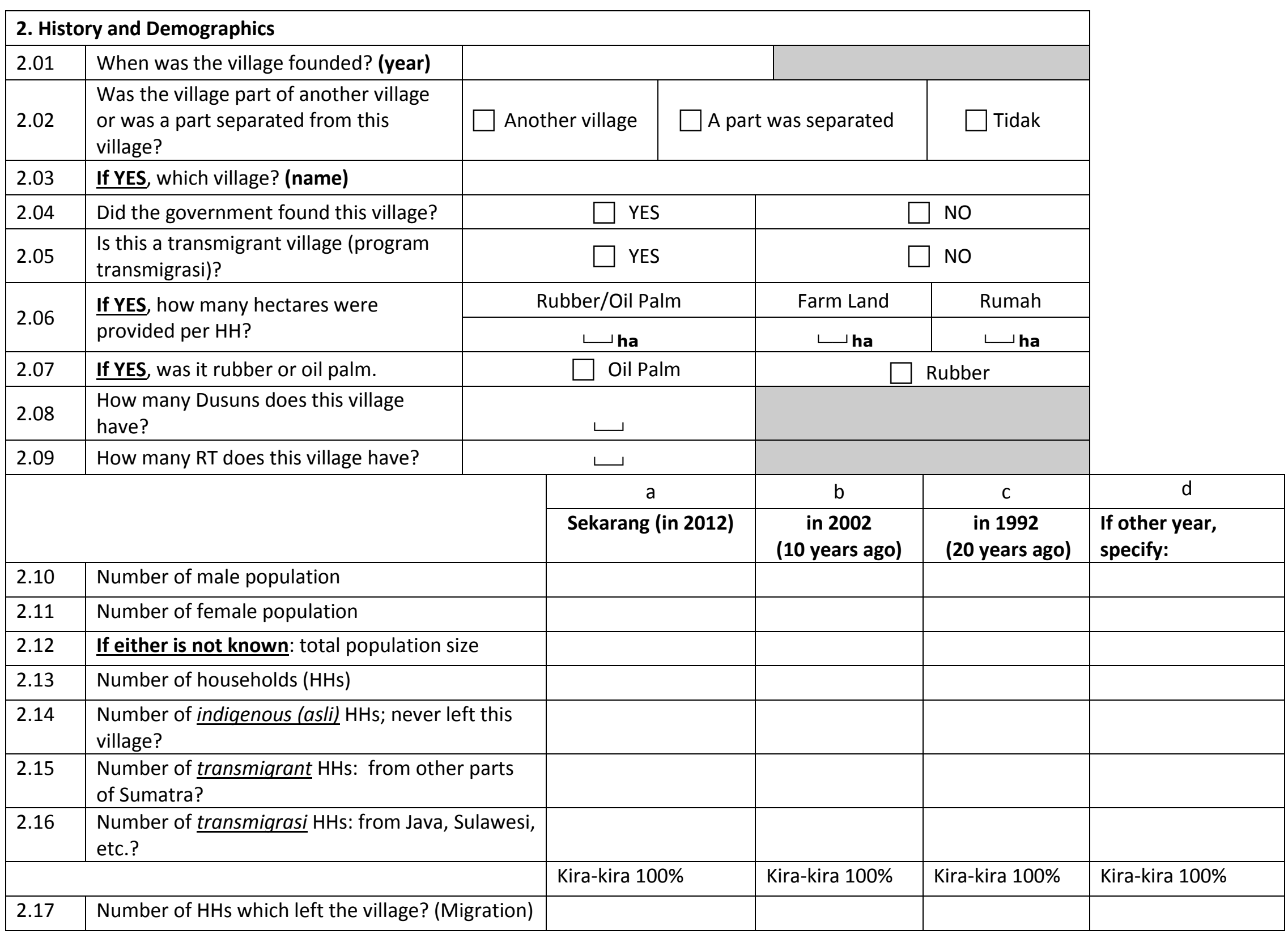




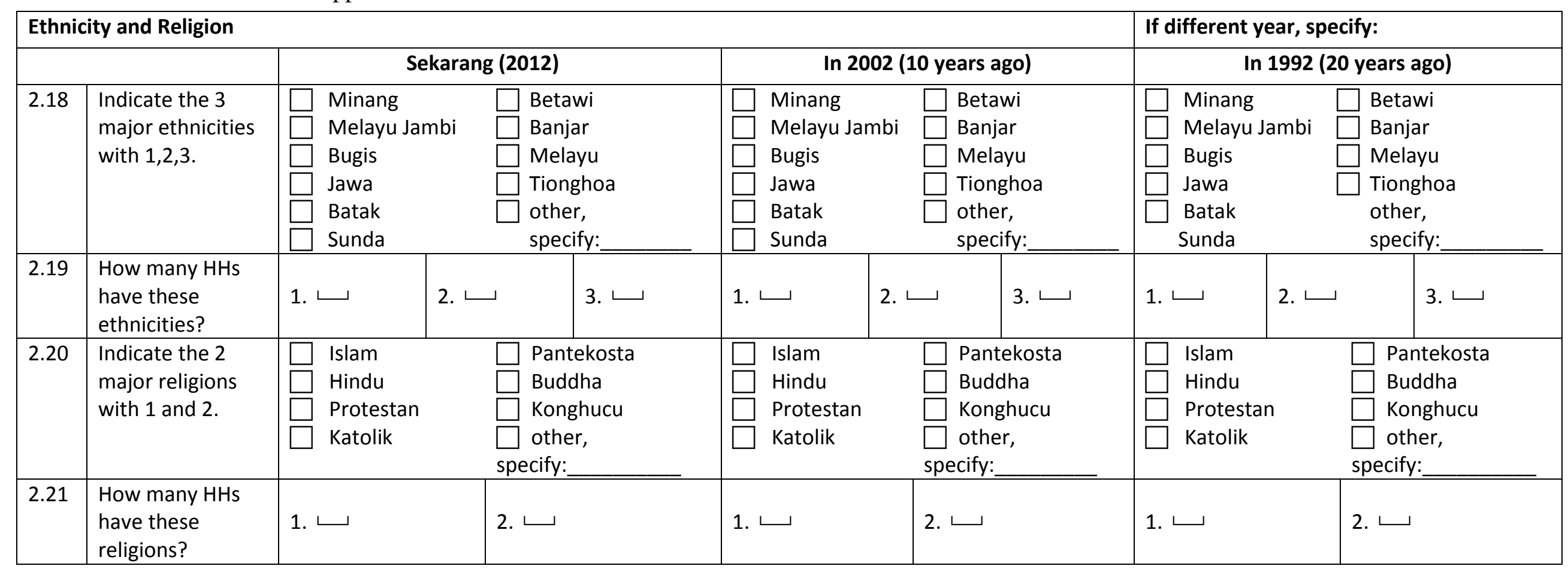

\begin{tabular}{|c|c|c|c|c|}
\hline \multirow[t]{3}{*}{3.} & \multicolumn{4}{|l|}{ Development Projects/External Funding } \\
\hline & a & $\mathrm{b}$ & c & $d$ \\
\hline & How many of the following programs did your village benefit from? & $\begin{array}{c}\text { When was program } \\
\text { introduced first } \\
\text { (year)? }\end{array}$ & $\begin{array}{l}\text { When was the program } \\
\text { introduced for the last time? } \\
\text { (ongoing=2012) }\end{array}$ & $\begin{array}{l}\text { Funding Institution } \\
\text { (see codes) }\end{array}$ \\
\hline 3.01 & Agriculture Aid/ Agricultural Extension (Training)/Microfinance & & & \\
\hline 3.02 & House (re)construction/Road (re)construction & & & \\
\hline 3.03 & Water and Sanitation/ Health & & & \\
\hline 3.04 & Education (for example, building schools, or scholarships, etc.) & & & \\
\hline 3.05 & Environmental/Forest Conservation & & & \\
\hline 3.06 & Other: & & & \\
\hline \multicolumn{5}{|c|}{ Codes for $3 \mathrm{~d}$ : Funding Institution } \\
\hline \multicolumn{2}{|c|}{$\begin{array}{l}1=\text { Head of Recency (Bupati) } \\
2=\text { Provincial Government (Jambi) }\end{array}$} & $\begin{array}{l}3=\text { Central Government (Jakarta) } \\
4=\text { NGO (LSM) }\end{array}$ & 5 = Other, specify: & \\
\hline
\end{tabular}




\subsection{Land Allocation}

\begin{tabular}{|l|l|l|l|l|l|}
\hline \multicolumn{2}{|c|}{ Specify the village land area in hectare! } & Sekarang (in 2012) & 2002 (10y ago) & 1992 (20y ago) & If other year, specify: __ \\
\hline 4.101 & Total village area & & & \\
\hline 4.102 & Agricultural Land & & & \\
\hline 4.103 & Rubber Plantation & & & \\
\hline 4.104 & Jungle Rubber & & & \\
\hline 4.105 & Palm Oil Plantation & & & \\
\hline 4.106 & Paddy & & & \\
\hline 4.107 & Other, specify: & & & \\
\hline 4.108 & Other Plantation Land (Gov. or Company) & & & \\
\hline 4.109 & Forest & & & \\
\hline 4.110 & Lahan Tidur & & & \\
\hline 4.111 & Non-Agricultural Land & & & \\
\hline
\end{tabular}

4.2 Land Slopes
\begin{tabular}{|l|l|c|c|c|c|c|c|}
\hline \multicolumn{2}{|l|}{ Estimate how many hectares have the following slopes (in ha; 99= not applicable; all hectare same slope= all) } \\
\hline 4.21 & Rubber Plantation: & $\mathbf{1}$ & $\mathbf{2}$ & $\mathbf{3}$ & $\mathbf{4}$ & $\mathbf{5}$ & $\mathbf{6}$ \\
\hline 4.22 & Jungle Rubber: & & & & & & \\
\hline 4.23 & Palm Oil Plantation: & & & & & & \\
\hline 4.24 & Forest: & & & & & & \\
\hline 4.25 & Waste/Sleeping/Fallow: & & & & & & \\
\hline 4.26 & Other: & & & & & & \\
\hline 4.27 & Other: & & & & & & \\
\hline
\end{tabular}

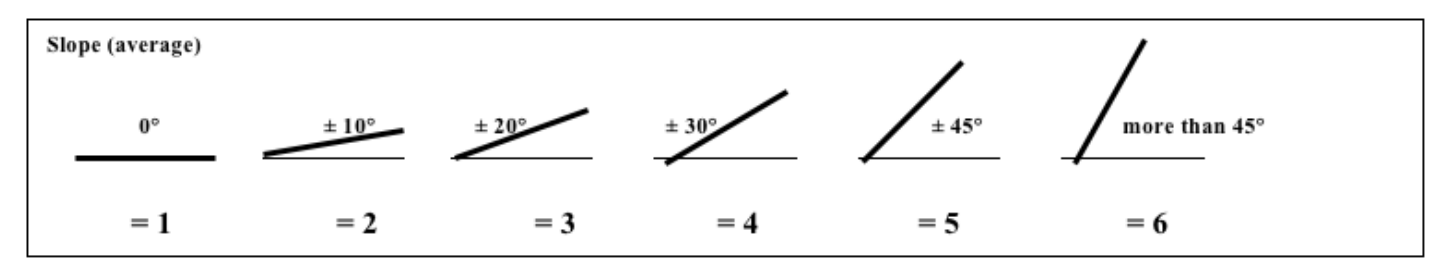




\begin{tabular}{|c|c|c|c|c|c|c|c|c|c|c|c|c|c|}
\hline \multicolumn{14}{|c|}{ 4.3 Land Ownership } \\
\hline \multirow{3}{*}{\multicolumn{2}{|c|}{$\begin{array}{l}\text { How many hectares of land are } \\
\text { owned by different stakeholders? }\end{array}$}} & \multicolumn{2}{|c|}{ a } & \multicolumn{2}{|c|}{$b$} & \multicolumn{2}{|c|}{ c } & \multicolumn{2}{|c|}{$d$} & \multicolumn{2}{|c|}{ e } & \multicolumn{2}{|c|}{$f$} \\
\hline & & \multicolumn{2}{|c|}{$\begin{array}{l}\text { Indigenous } \\
\text { Villagers }\end{array}$} & \multicolumn{2}{|c|}{$\begin{array}{c}\text { Transmigrant } \\
\text { Villagers } \\
\text { (other parts of } \\
\text { Sumatra) }\end{array}$} & \multicolumn{2}{|c|}{$\begin{array}{c}\text { Transmigrasi } \\
\text { Villagers } \\
\text { (from Java, } \\
\text { Sulawesi, etc.) }\end{array}$} & \multicolumn{2}{|c|}{$\begin{array}{l}\text { Do Companies or } \\
\text { Government own } \\
\text { land in this village? }\end{array}$} & \multicolumn{2}{|c|}{$\begin{array}{c}\text { COMPANY: } \\
\text { If YES, how much? }\end{array}$} & \multicolumn{2}{|c|}{$\begin{array}{l}\text { GOVERNMENT: } \\
\text { If YES, how much? }\end{array}$} \\
\hline & & 2012 & 2002 & 2012 & 2002 & 2012 & 2002 & $\square \mathrm{Ya}$ & $\square$ Tdk & 2012 & 2002 & 2012 & 2002 \\
\hline \multicolumn{14}{|c|}{ If different year, write here: } \\
\hline 4.31 & Rubber Plantation: & & & & & & & & & & & & \\
\hline 4.32 & Jungle Rubber: & & & & & & & & & & & & \\
\hline 4.33 & Palm Oil Plantation: & & & & & & & & & & & & \\
\hline 4.34 & Forest: & & & & & & & & & & & & \\
\hline 4.35 & Waste/Sleeping/Fallow & & & & & & & & & & & & \\
\hline 4.36 & Other: & & & & & & & & & & & & \\
\hline 4.37 & Other: & & & & & & & & & & & & \\
\hline
\end{tabular}

\begin{tabular}{|c|c|c|c|c|c|}
\hline \multicolumn{6}{|c|}{ 4.4 Land Rights } \\
\hline 4.41 & \multicolumn{3}{|l|}{ How many HHs hold Adat land rights? } & \multicolumn{2}{|c|}{ 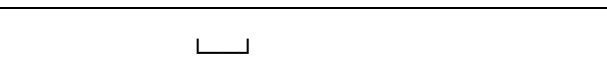 } \\
\hline 4.42 & \multicolumn{3}{|c|}{ How many HHs have land rights established on village consent? } & \multicolumn{2}{|c|}{$\longleftarrow$} \\
\hline 4.43 & \multicolumn{2}{|l|}{ How many HHs have land rights from the government? } & & \multicolumn{2}{|c|}{\llcorner} \\
\hline \multirow{2}{*}{\multicolumn{2}{|c|}{$\begin{array}{l}\text { Specify the land rights for the following sub-groups. } \\
\text { (99= not applicable) }\end{array}$}} & a & $\mathrm{b}$ & $\mathrm{C}$ & $\mathrm{d}$ \\
\hline & & $\begin{array}{l}\text { Land Rights } \\
\text { (Adat \& } \\
\text { Consent) }\end{array}$ & $\begin{array}{l}\text { How many HHs } \\
\text { have land right } \\
\text { certificate not } \\
\text { from gov.? }\end{array}$ & $\begin{array}{l}\text { Formal } \\
\text { Government } \\
\text { Certificate }\end{array}$ & $\begin{array}{l}\text { When obtained from } \\
\text { government? } \\
\text { (year) }\end{array}$ \\
\hline 4.44 & Indigenous Villagers asli & $\longleftarrow$ & $\longleftarrow$ & $\sqcup$ & \\
\hline 4.45 & Transmigrant Villagers (from other parts of Sumatra) & 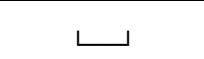 & 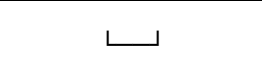 & 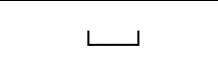 & \\
\hline 4.46 & Transmigrasi Villagers (from Java, Sulawesi, etc.) & 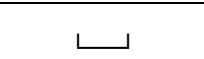 & 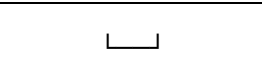 & 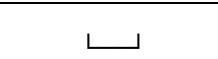 & \\
\hline 4.47 & Private Company: & & & 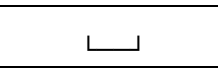 & \\
\hline 4.48 & 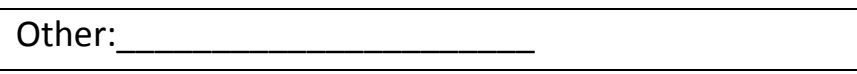 & $\longleftarrow$ & $\longleftarrow$ & $\sqcup$ & \\
\hline
\end{tabular}




\begin{tabular}{|c|c|c|c|c|c|c|c|c|c|}
\hline \multicolumn{10}{|c|}{ 5. Logging } \\
\hline 5.1 & \multicolumn{4}{|c|}{ Has logging taken place in your village } & \multicolumn{3}{|c|}{$\square \mathrm{Ya}$} & \multicolumn{2}{|c|}{$\square$ Tidak } \\
\hline \multicolumn{10}{|c|}{ If YES, please specify the following. If NO, skip this section. } \\
\hline & $a$ & $\mathrm{~b}$ & c & \multicolumn{2}{|c|}{$d$} & \multicolumn{2}{|c|}{$\mathrm{e}$} & \multicolumn{2}{|c|}{$f$} \\
\hline & Year & $\begin{array}{c}\text { How much } \\
\text { area? } \\
\text { (in hectares) }\end{array}$ & $\begin{array}{l}\text { Who did the } \\
\text { logging? } \\
\text { (see codes) }\end{array}$ & \multicolumn{2}{|c|}{ Legal Logging? } & \multicolumn{2}{|c|}{$\begin{array}{l}\text { Main land usage } \\
\frac{\text { after logging }}{\text { (see codes) }}\end{array}$} & \multicolumn{2}{|c|}{$\begin{array}{c}\text { Land Size after logging } \\
\text { (in hectares) }\end{array}$} \\
\hline \multirow[t]{2}{*}{5.2} & & \multirow[b]{2}{*}{$\sqcup_{\text {ha }}$} & \multirow[b]{2}{*}{$\sqcup$} & \multirow[b]{2}{*}{$\square \mathrm{Ya}$} & \multirow[b]{2}{*}{$\square$ Tdk } & 1. & 2. & 1. & 2. \\
\hline & & & & & & & & & \\
\hline \multirow[t]{2}{*}{5.3} & & \multirow[b]{2}{*}{$\smile$ ha } & \multirow[b]{2}{*}{$\longleftarrow$} & \multirow[b]{2}{*}{$\square \mathrm{Ya}$} & \multirow{2}{*}{$\square$ Tdk } & 1. & 2. & 1. & 2. \\
\hline & & & & & & & & & \\
\hline \multirow[t]{2}{*}{5.4} & & \multirow[b]{2}{*}{$\smile$ ha } & \multirow[b]{2}{*}{$\sqcup$} & \multirow[b]{2}{*}{$\square \mathrm{Ya}$} & \multirow[b]{2}{*}{$\square$ Tdk } & 1. & 2. & 1. & 2. \\
\hline & & & & & & & & & \\
\hline \multirow[t]{2}{*}{5.5} & & \multirow[b]{2}{*}{$\longleftarrow$ ha } & \multirow[b]{2}{*}{$\longleftarrow$} & \multirow[b]{2}{*}{$\square \mathrm{Ya}$} & \multirow[b]{2}{*}{$\square$ Tdk } & 1. & 2. & 1. & 2. \\
\hline & & & & & & & & & \\
\hline \multirow[t]{2}{*}{5.6} & & \multirow[b]{2}{*}{$\longleftarrow$ ha } & \multirow[b]{2}{*}{$\sqcup$} & \multirow[b]{2}{*}{$\square \mathrm{Ya}$} & & 1. & 2. & 1. & 2. \\
\hline & & & & & $\square$ Tdk & & & & \\
\hline 5.7 & & & & & & 1. & 2. & 1. & 2. \\
\hline & & $\sqcup_{\text {ha }}$ & $\sqcup$ & $\mathrm{Ya}$ & $\square$ Tdk & & & & \\
\hline & Cod & or 5c: Who did & e logging & Cod & s for $5 e: L$ & d Usag & r Logg & & \\
\hline $\begin{array}{l}1=P \\
2=c \\
3=1 \\
4=c\end{array}$ & $\begin{array}{l}\text { late Com } \\
\text { vernmen } \\
\text { ividuals } \\
\text { ers, spe }\end{array}$ & & & $\begin{array}{l}1=R \\
2=J \\
3=C \\
4=R \\
5=F \\
6=R \\
7=C \\
8=C\end{array}$ & $\begin{array}{l}\text { bber Plan } \\
\text { ngle Rubb } \\
\text { I Palm Plar } \\
\text { forestatio } \\
\text { llow/ Slee } \\
\text { ce } \\
\text { her, speci } \\
\text { her, speci }\end{array}$ & $\begin{array}{l}\text { on } \\
\text { tion } \\
\text { g Land }\end{array}$ & & & \\
\hline
\end{tabular}


Appendix B

134

\section{Economic Situation}

\begin{tabular}{|c|c|c|c|c|c|}
\hline & $\begin{array}{l}\text { Estimate the number of } \underline{\mathrm{HHs}} \text { or } \% \text { for which } \\
\text { this activity is the MAIN source of income! }\end{array}$ & In 2012 & $\begin{array}{c}\text { In } 2002 \\
\text { (10 years ago) }\end{array}$ & $\begin{array}{c}\text { In } 1992 \\
\text { (20 years ago) }\end{array}$ & $\begin{array}{l}\text { If different } \\
\text { year: }\end{array}$ \\
\hline 6.01 & Agriculture & 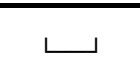 & 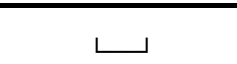 & $\longleftarrow$ & 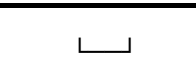 \\
\hline 6.02 & Rubber Plantation & $\sqcup$ & $\sqcup$ & $\sqcup$ & $\sqcup$ \\
\hline 6.03 & Jungle Rubber & - & $\sqcup$ & 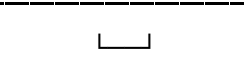 & $\sqcup$ \\
\hline 6.04 & Palm Oil & 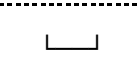 & $\sqcup$ & $\sqcup$ & $\sqcup$ \\
\hline 6.05 & Paddy & 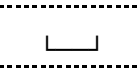 & $\longleftarrow$ & $\longleftarrow$ & 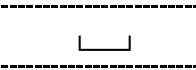 \\
\hline 6.06 & Horticulture & 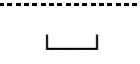 & 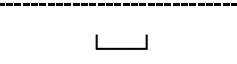 & $\longleftarrow$ & 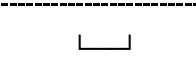 \\
\hline 6.07 & Husbandry & $\sqcup$ & $\sqcup$ & $\sqcup$ & $\sqcup$ \\
\hline 6.08 & Forestry & $\sqcup$ & $\sqcup$ & $\longleftarrow$ & $\sqcup$ \\
\hline 6.09 & Mining & 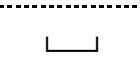 & 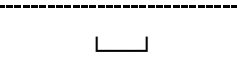 & 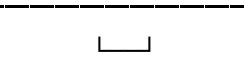 & 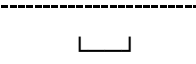 \\
\hline 6.10 & Retailer/Vendor & $\longleftarrow$ & 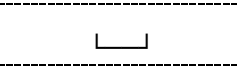 & $\longleftarrow$ & $\longleftarrow$ \\
\hline 6.11 & Trader & $\longleftarrow$ & $\sqcup$ & $\longleftarrow$ & $\longleftarrow$ \\
\hline 6.12 & Transport/Lender (Storage, Land, Credit) & $\sqcup$ & $\sqcup$ & $\sqcup$ & $\sqcup$ \\
\hline 6.13 & Public Service & & & & \\
\hline 6.14 & Civil Servant (orang) & 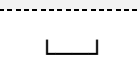 & $\sqcup$ & \llcorner & $\sqcup$ \\
\hline 6.15 & Police (orang) & 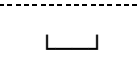 & 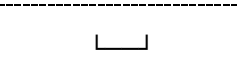 & $\longleftarrow$ & $\sqcup$ \\
\hline 6.16 & Military (TNI) (orang) & $\longleftarrow$ & $\longleftarrow$ & $\longleftarrow$ & $\longleftarrow$ \\
\hline 6.17 & Health Doctor (orang) & $\sqcup$ & $\longleftarrow$ & $\longleftarrow$ & $\longleftarrow$ \\
\hline 6.18 & Pension/Retired (orang) & $\sqcup$ & 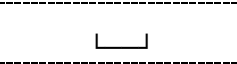 & 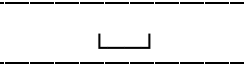 & $\sqcup$ \\
\hline 6.19 & Other (important), specify: & $\longleftarrow$ & $\longleftarrow$ & $\longleftarrow$ & $\longleftarrow$ \\
\hline 6.20 & Other (important), specify: & $\square$ & 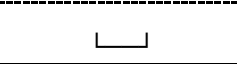 & 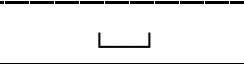 & 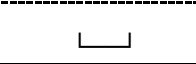 \\
\hline
\end{tabular}

\begin{tabular}{|c|c|c|c|c|c|c|c|c|}
\hline 7.1 & \multicolumn{4}{|c|}{$\begin{array}{l}\text { Has your village received any payments/compensation for } \\
\text { preserving the forest? }\end{array}$} & & \multicolumn{2}{|l|}{$\square \mathrm{Ya}$} & $\square$ Tidak \\
\hline \multirow[t]{3}{*}{7.11} & \multicolumn{8}{|c|}{ If YES, please indicate all payments/compensation the village received from either NGO or government } \\
\hline & a & $\mathrm{b}$ & C & & & e & $\mathrm{f}$ & g \\
\hline & Name Organization & $\begin{array}{c}\text { Starting } \\
\text { Year }\end{array}$ & $\begin{array}{l}\text { Ending } \\
\text { Year } \\
\text { (2012 = } \\
\text { ongoing) }\end{array}$ & $\begin{array}{l}\text { Cond } \\
\text { (see c }\end{array}$ & $\begin{array}{l}\text { tions } \\
\text { des) }\end{array}$ & $\begin{array}{l}\text { equency } \\
\text { payment } \\
\text { e codes) }\end{array}$ & $\begin{array}{l}\text { Amount } \\
\text { (in Rph) }\end{array}$ & $\begin{array}{l}\text { Compensation } \\
\text { in } \\
\text { infrastructure? } \\
\text { (see codes) }\end{array}$ \\
\hline \multicolumn{9}{|l|}{7.12} \\
\hline \multicolumn{9}{|l|}{7.13} \\
\hline \multicolumn{9}{|l|}{7.14} \\
\hline \multicolumn{9}{|l|}{7.15} \\
\hline \multicolumn{2}{|c|}{ Codes for 7.1d: Conditions } & \multicolumn{4}{|c|}{ Codes for 7.1e: Frequency } & \multicolumn{3}{|c|}{ Codes for 7.1g: Infrastructure } \\
\hline \multicolumn{2}{|c|}{$\begin{array}{l}1=\text { No burning } \\
2=\text { No logging } \\
3=\text { Conservation (no use at all) } \\
4=\text { Other }, \text { specify: }\end{array}$} & \multicolumn{4}{|c|}{$\begin{array}{l}1=\text { once (lumpsum) } \\
2=\text { monthly basis } \\
3=\text { yearly basis } \\
4=\text { other } \text { specify: }\end{array}$} & \multicolumn{3}{|c|}{$\begin{array}{l}1=\text { road }(\text { re)contruction } \\
2=\text { school } \\
3=\text { health clinic } \\
4=\text { other }, \text { specify: }\end{array}$} \\
\hline
\end{tabular}




\begin{tabular}{|c|c|c|c|c|c|}
\hline \multicolumn{6}{|c|}{ 8. Farm gate prices } \\
\hline \multirow{2}{*}{\multicolumn{2}{|c|}{$\begin{array}{l}\text { Estimate the farm gate prices } \\
\text { for the specific crop/input }\end{array}$}} & $\mathrm{a}$ & C & $d$ & $\mathrm{e}$ \\
\hline & & $\ln 2012$ & $\begin{array}{c}\text { in } 2002 \\
\text { (10 years ago) }\end{array}$ & $\begin{array}{c}\text { In } 1992 \\
\text { (20 years ago) }\end{array}$ & If different year: \\
\hline 8.1 & Oil Palm (1 kg) & $\llcorner\mathrm{Rp}$ & $\llcorner\mathrm{Rp}$ & $\sqcup_{\mathrm{Rp}}$ & $\sqcup_{\mathrm{Rp}}$ \\
\hline 8.2 & Rubber (1 kg) & $\llcorner\mathrm{Rp}$ & $\smile \mathrm{Rp}$ & $\smile \mathrm{Rp}$ & $\smile \mathrm{Rp}$ \\
\hline 8.3 & Rice (1 kg) & $\longleftarrow \mathrm{Rp}$ & $\smile \mathrm{Rp}$ & $\smile \mathrm{Rp}$ & $\smile \mathrm{Rp}$ \\
\hline 8.4 & Fertilizer (1 kg) & $\llcorner\mathrm{Rp}$ & $\llcorner\mathrm{Rp}$ & \lrcorner$_{\mathrm{Rp}}$ & $\mathrm{Rp}_{\mathrm{Rp}}$ \\
\hline 8.5 & Wage Labour (per day) & $\llcorner\mathrm{Rp}$ & $\llcorner\mathrm{Rp}$ & $\sqcup_{\mathrm{Rp}}$ & $\sqcup_{\mathrm{Rp}}$ \\
\hline 8.6 & Other, specify: & $\smile \mathrm{Rp}$ & $\sqcup_{\mathrm{Rp}}$ & $\sqcup_{\mathrm{Rp}}$ & \lrcorner$_{\mathrm{Rp}}$ \\
\hline
\end{tabular}

\begin{tabular}{|c|c|c|c|c|c|}
\hline \multicolumn{6}{|c|}{ 9. Village Assets } \\
\hline \multirow{2}{*}{\multicolumn{2}{|c|}{$\begin{array}{l}\text { Indicate the number of } \underline{\mathrm{HHs}} \text { or } \\
\text { \% possessing the following } \\
\text { assets }\end{array}$}} & $a$ & $b$ & c & \\
\hline & & $\ln 2012$ & $\begin{array}{c}\text { in } 2002 \\
\text { (10 years ago) }\end{array}$ & $\begin{array}{c}\text { in } 1992 \\
\text { (20 years ago) }\end{array}$ & If different year: \\
\hline 9.01 & Television & 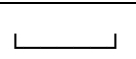 & $\checkmark$ & $\checkmark$ & 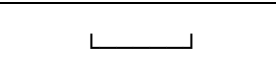 \\
\hline 9.02 & Satellite Dish & 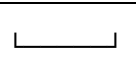 & 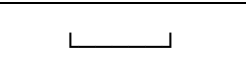 & ــ & 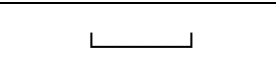 \\
\hline 9.03 & Motor Cycle & $\longleftarrow$ & $\longleftarrow$ & $\longleftarrow$ & $\longleftarrow$ \\
\hline 9.04 & Car & 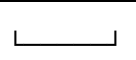 & 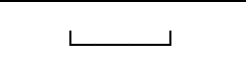 & \llcorner & $\longleftarrow$ \\
\hline 9.05 & Truck & 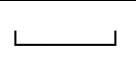 & 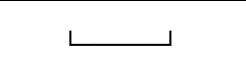 & 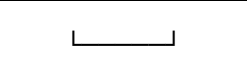 & 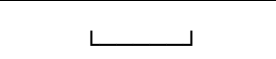 \\
\hline 9.06 & Kulkas & 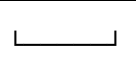 & 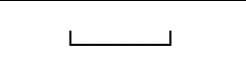 & 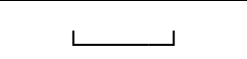 & 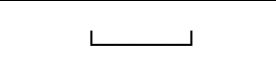 \\
\hline 9.07 & Air-conditioner & 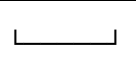 & 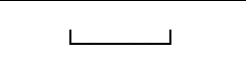 & 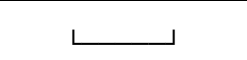 & 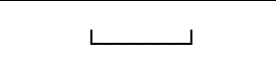 \\
\hline 9.08 & Cellphone & $\longleftarrow$ & 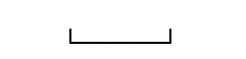 & 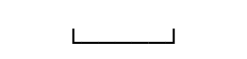 & $\longleftarrow$ \\
\hline 9.09 & Computer & $\longleftarrow$ & $\longleftarrow$ & $\longleftarrow$ & $\longleftarrow$ \\
\hline 9.10 & Generator & 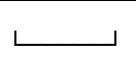 & 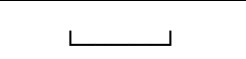 & 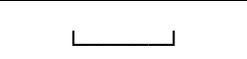 & 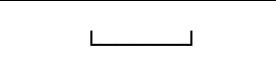 \\
\hline 9.11 & $\begin{array}{l}\text { How many HHs have } \\
\text { more than } 10 \text { ha oil } \\
\text { palm/rubber? }\end{array}$ & 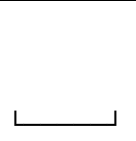 & 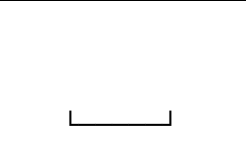 & 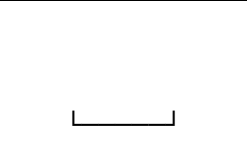 & 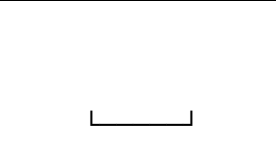 \\
\hline
\end{tabular}




\begin{tabular}{|c|c|c|c|c|c|}
\hline \multicolumn{6}{|c|}{ 10. Village Facilities and Access } \\
\hline \multirow{2}{*}{\multicolumn{2}{|c|}{$\begin{array}{l}\text { How far are the following facility/services } \\
\text { starting from the village head office? (in } \\
\text { kilometers!) }\end{array}$}} & $a$ & $\mathrm{~b}$ & c & $d$ \\
\hline & & Sekarang (2012) & $\begin{array}{c}\ln 2002 \\
\text { (10 years ago) }\end{array}$ & $\begin{array}{c}\text { in } 1992 \\
\text { (20 years ago) }\end{array}$ & $\begin{array}{c}\text { If different } \\
\text { year: }\end{array}$ \\
\hline 10.01 & Vehicle Road (asphalt road) & $\sqcup$ & $\longleftarrow$ & $\longleftarrow$ & $\sqcup$ \\
\hline 10.02 & Hospital/ Clinic & $\longleftarrow$ & $\longleftarrow$ & $\longleftarrow$ & $\longleftarrow$ \\
\hline 10.03 & Primary School & $\longleftarrow$ & $\longleftarrow$ & $\longleftarrow$ & $\longleftarrow$ \\
\hline 10.04 & Junior High School & $\longleftarrow$ & $\sqcup$ & $\longleftarrow$ & $\sqcup$ \\
\hline 10.05 & Senior High School & $\longleftarrow$ & $\longleftarrow$ & $\longleftarrow$ & $\longleftarrow$ \\
\hline 10.06 & Police Station & $\sqcup$ & $\sqcup$ & $\sqcup$ & $\sqcup$ \\
\hline 10.07 & Post Office & $\sqcup$ & $\sqcup$ & $\sqcup$ & $\sqcup$ \\
\hline 10.08 & Market & $\longleftarrow$ & $\longleftarrow$ & $\longleftarrow$ & $\longleftarrow$ \\
\hline 10.09 & River & $\longleftarrow$ & $\longleftarrow$ & $\longleftarrow$ & $\longleftarrow$ \\
\hline 10.10 & Lake & $\longleftarrow$ & $\longleftarrow$ & $\longleftarrow$ & $\longleftarrow$ \\
\hline 10.11 & Well/Spring & $\longleftarrow$ & $\longleftarrow$ & $\longleftarrow$ & $\longleftarrow$ \\
\hline 10.12 & National Park & $\longleftarrow$ & $\longleftarrow$ & $\longleftarrow$ & $\longleftarrow$ \\
\hline 10.13 & Closest Neighboring Village: & $\longleftarrow$ & $\longleftarrow$ & $\longleftarrow$ & $\longleftarrow$ \\
\hline 10.14 & Closest Oil Palm Mill & $\longleftarrow$ & $\longleftarrow$ & $\longleftarrow$ & $\longleftarrow$ \\
\hline 10.15 & Closest Rubber Buying Point & $\longleftarrow$ & $\longleftarrow$ & $\longleftarrow$ & $\longleftarrow$ \\
\hline 10.16 & NGO: & $\longleftarrow$ & $\longleftarrow$ & $\longleftarrow$ & $\longleftarrow$ \\
\hline 10.17 & Electricity & \begin{tabular}{|l|l|} 
Ya & $\square \mathrm{Tdk}$ \\
\end{tabular} & \begin{tabular}{|l|l|}
$\square \mathrm{Ya}$ & $\square \mathrm{Tdk}$ \\
\end{tabular} & \begin{tabular}{l|l}
$\square \mathrm{Ya}$ \\
$\square$
\end{tabular} & \begin{tabular}{l|ll}
$\mathrm{Ya}$ & $\square \mathrm{Tdk}$ \\
\end{tabular} \\
\hline 10.18 & Signal & $\begin{array}{ll}\square \text { Good } \\
\square \text { Moderate } \\
\square \text { Poor } \\
\end{array}$ & \begin{tabular}{|l|}
$\square$ Good \\
$\square$ Moderate \\
$\square$ Poor \\
\end{tabular} & \begin{tabular}{|l|}
$\square$ Good \\
$\square$ Moderate \\
$\square$ Poor \\
\end{tabular} & $\begin{array}{ll}\square \text { Good } \\
\square \text { Moderate } \\
\square \text { Poor } \\
\end{array}$ \\
\hline
\end{tabular}

\begin{tabular}{|c|c|c|c|c|c|}
\hline \multicolumn{6}{|c|}{ 11. Water Quality } \\
\hline & & 1992 (20 year ago) & 2002 (10 years ago) & & Sekarang (2012) \\
\hline 11.1 & $\begin{array}{l}\text { Estimate what the water quality } \\
\text { is/was? }\end{array}$ & $\begin{array}{l}\square \text { High quality } \\
\square \text { Medium quality } \\
\square \text { Low Quality }\end{array}$ & $\begin{array}{l}\square \text { Worse than } 1992 \\
\square \quad \text { Better than } 1992 \\
\square \quad \text { Same }\end{array}$ & & $\begin{array}{l}\text { Worse than } 2002 \\
\text { Better than } 2002 \\
\text { same }\end{array}$ \\
\hline 11.2 & \multicolumn{2}{|c|}{$\begin{array}{l}\text { If water quality worse than in 1992, what are the reasons } \\
\text { for the lower water quality? }\end{array}$} & \multicolumn{3}{|c|}{$\begin{array}{l}\square \text { Palm Oil Mills } \\
\square \text { Application of fertilizer/pesticides/herbicides } \\
\square \text { Other Industry } \\
\square \text { Dumping waste in river } \\
\square \text { Others, specify: }\end{array}$} \\
\hline
\end{tabular}




\begin{tabular}{|c|c|c|c|c|c|}
\hline \multicolumn{6}{|c|}{ 12. Access to Food } \\
\hline 12.01 & \multicolumn{2}{|c|}{ How is the availability of food in the village? } & \multicolumn{2}{|c|}{$1=$ plenty; $2=$ =nough; $3=$ not enough } & 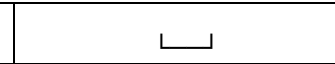 \\
\hline 12.02 & \multicolumn{2}{|c|}{ How many HHs cannot afford 3 rice meals/day? } & \multicolumn{3}{|c|}{$ـ$} \\
\hline 12.03 & \multicolumn{2}{|c|}{$\begin{array}{l}10 \text { years ago, was the amount of } \mathrm{HHs} \text { unable to } \\
\text { afford } 3 \text { rice meals/day... }\end{array}$} & \multicolumn{2}{|c|}{$1=$ more; $2=$ same; $3=$ less } & 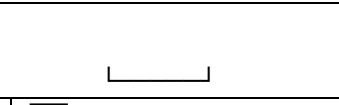 \\
\hline 12.04 & \multicolumn{3}{|c|}{ Have you had any periods of food shortage or famines? } & $\square \mathrm{Ya}$ & $\square$ Tidak \\
\hline \multirow[t]{3}{*}{12.05} & \multicolumn{5}{|c|}{ If YES, during the past $\mathbf{2 0}$ years, mention all the periods of food shortage or famines. If NO , skip the next section! } \\
\hline & a & & $\mathrm{b}$ & & C \\
\hline & When was it? (year) & Ending & ear (2012=ongoing) & How many $\mathrm{HH}$ & $\begin{array}{l}\text { receive food aid due } \\
\text { e shock? }\end{array}$ \\
\hline 12.06 & $\longleftarrow$ & & $\longleftarrow$ & & 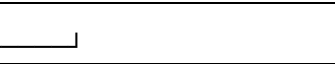 \\
\hline 12.07 & $\longleftarrow$ & & $\longleftarrow$ & & $\longrightarrow$ \\
\hline 12.08 & $\longleftarrow$ & & $\longleftarrow$ & & 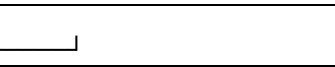 \\
\hline 12.09 & $\longleftarrow$ & & $\longleftarrow$ & & $\longrightarrow$ \\
\hline 12.10 & $\longleftarrow$ & & 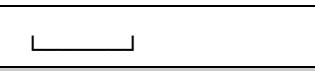 & & $\longrightarrow$ \\
\hline 12.11 & How many HHs get surat misk & $\sin 2012$ & & & $\longrightarrow$ \\
\hline
\end{tabular}

\begin{tabular}{|c|c|c|c|c|c|}
\hline \multicolumn{6}{|c|}{ 13. Technology Usage } \\
\hline \multirow{2}{*}{\multicolumn{2}{|c|}{$\begin{array}{l}\text { Estimate the number of } \mathrm{HHs} \text { which } \\
\text { use the following technologies for } \\
\text { agriculture. (99=not applicable) }\end{array}$}} & $a$ & $\mathrm{~b}$ & c & $d$ \\
\hline & & $\ln 2012$ & $\begin{array}{c}\ln 2002 \\
\text { (10 years ago) }\end{array}$ & $\begin{array}{c}\ln 1992 \\
\text { (20 years ago) }\end{array}$ & If different year: \\
\hline 13.1 & Irrigation (lake/river) & $\longleftarrow$ & 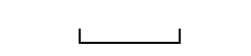 & 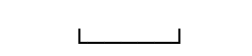 & 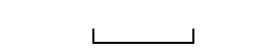 \\
\hline 13.2 & Irrigation (well/pump) & 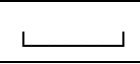 & $\longleftarrow$ & $\longleftarrow$ & $\longleftarrow$ \\
\hline 13.3 & Mulching & $\longleftarrow$ & $\longleftarrow$ & $\longleftarrow$ & $\longleftarrow$ \\
\hline 13.4 & Manure & $\sqcup$ & 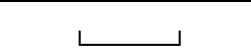 & 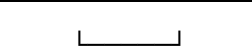 & 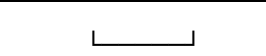 \\
\hline 13.5 & Chemical Fertilizer & $\sqcup$ & $\longleftarrow$ & $\longleftarrow$ & $\longleftarrow$ \\
\hline 13.6 & Pesticides & $\longleftarrow$ & $\longleftarrow$ & 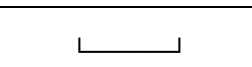 & 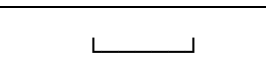 \\
\hline 13.7 & Herbicides & $\sqcup$ & $\longleftarrow$ & $\longleftarrow$ & $\longleftarrow$ \\
\hline 13.8 & Hand Tractor & $\longleftarrow$ & $\longleftarrow$ & 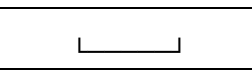 & $\longleftarrow$ \\
\hline 13.9 & Improved Seeds & 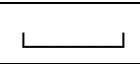 & $\longleftarrow$ & $\longleftarrow$ & $\longleftarrow$ \\
\hline
\end{tabular}




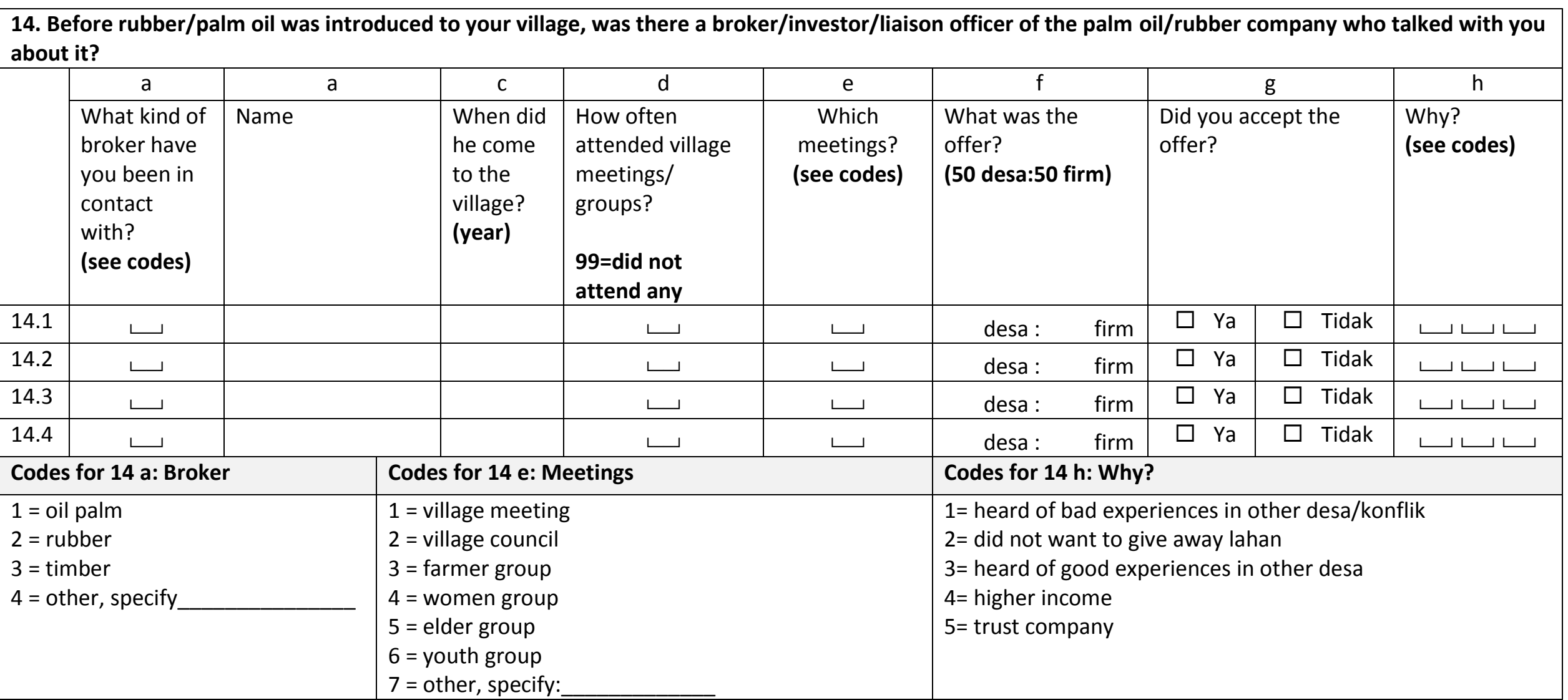




\begin{tabular}{|c|c|c|c|c|c|}
\hline \multicolumn{6}{|c|}{ 15. Cooperatives and Oil Palm Company } \\
\hline \multirow[t]{2}{*}{15.1} & \multirow{2}{*}{ How many farmer cooperatives are in the village? } & \multirow{2}{*}{ a } & Rubber & \multirow{2}{*}{$\mathrm{b}$} & Oil Palm \\
\hline & & & 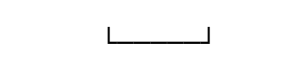 & & 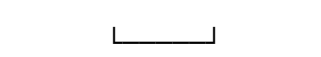 \\
\hline \multirow[t]{2}{*}{15.2} & \multirow{2}{*}{$\begin{array}{l}\text { For Oil Palm Farmers: how many are in } \\
\text { cooperation and how many independent? }\end{array}$} & \multirow{2}{*}{ a } & Farmer Cooperative & \multirow{2}{*}{$\mathrm{b}$} & Independent Farmers \\
\hline & & & 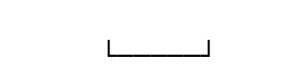 & & ـ ب \\
\hline \multirow[t]{2}{*}{15.3} & \multirow{2}{*}{$\begin{array}{l}\text { For Rubber Farmers: how many are in } \\
\text { cooperation and how many are independent? }\end{array}$} & \multirow{2}{*}{ a } & Farmer Cooperative & \multirow{2}{*}{$\mathrm{b}$} & Independent Farmers \\
\hline & & & 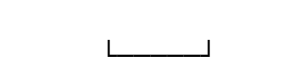 & & 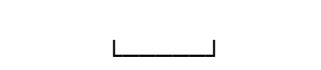 \\
\hline 15.4 & \multicolumn{3}{|c|}{ How many oil palm companies operate close to the village? } & \multicolumn{2}{|r|}{ 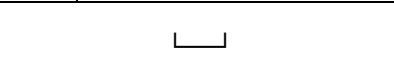 } \\
\hline 15.5 & \multicolumn{3}{|l|}{ How many mills for oil palm are in the village area? } & \multicolumn{2}{|r|}{ 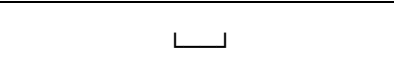 } \\
\hline \multirow[t]{2}{*}{15.6} & \multicolumn{3}{|c|}{ When was the first oil palm mill that you supply to established? (year) } & & \\
\hline & \multicolumn{3}{|c|}{ What is the name of the company that this mill belongs to? (nama) } & & \\
\hline
\end{tabular}

The next sections is for contract famers only! If there are no contracts between oil palm companies and farmer cooperatives/villages skip to the next section!

16.1 For the contracts between oil palm companies and farmer cooperatives/villages specify the following:

\begin{tabular}{|c|c|c|c|c|c|c|c|c|}
\hline \multirow[t]{2}{*}{16.11} & a & $\mathrm{b}$ & C & $d$ & e & $f$ & \multicolumn{2}{|c|}{ g } \\
\hline & Name Company & $\begin{array}{l}\text { Company } \\
\text { Type } \\
\text { (see codes) }\end{array}$ & $\begin{aligned} & \text { Contract } \\
& \text { Partner } \\
& \text { 1= Cooperative } \\
& \text { 2= Village }\end{aligned}$ & $\begin{array}{l}\text { Who signed } \\
\text { contract? } \\
\text { (see codes) }\end{array}$ & $\begin{array}{c}\text { Contract } \\
\text { Start (year) }\end{array}$ & $\begin{array}{l}\text { Contract } \\
\text { End } \\
\text { (year) }\end{array}$ & \multicolumn{2}{|c|}{$\begin{array}{c}\text { Agreement } \\
\text { written down? }\end{array}$} \\
\hline 16.12 & & $\longleftarrow$ & $\sqcup$ & $\sqcup \sqcup \sqcup \sqcup$ & & & $\square$ Yes & $\square$ No \\
\hline 16.13 & & $\longleftarrow$ & $\longleftarrow$ & $\sqcup \sqcup \sqcup \sqcup$ & & & $\square$ Yes & $\square$ No \\
\hline 16.14 & & $\longleftarrow$ & $\longleftarrow$ & $\longleftarrow\llcorner\llcorner$ & & & $\square$ Yes & $\square$ No \\
\hline 16.15 & & $\longleftarrow$ & $\longleftarrow$ & 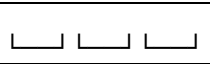 & & & $\square$ Yes & $\square$ No \\
\hline \multicolumn{4}{|c|}{ Codes for 16.1 b: Company Type } & \multicolumn{5}{|c|}{ Codes for $16.1 \mathrm{~d}$ : Signing Contract } \\
\hline \multicolumn{4}{|c|}{$\begin{array}{l}\text { 1= Perusahaan Terbatas Perkebunan Nasional (PTPN) } \\
\text { 2= Private Company regulated through Badan Koordinasi } \\
\text { Penanaman Modal (BKPM) } \\
\text { 3= Private Company } \\
4=\text { Other, specify: } \\
\text { 99= don't know }\end{array}$} & \multicolumn{5}{|c|}{$\begin{array}{l}\text { 1= Leaders Cooperative } \\
\text { 2= Village Leader } \\
\text { 3= Farmers } \\
\text { 4=Others: }\end{array}$} \\
\hline
\end{tabular}




\begin{tabular}{|c|c|c|c|c|c|c|}
\hline \multicolumn{7}{|c|}{ 16.2 Contractual Conditions between village/cooperative and the oil palm company (OP) } \\
\hline 16.201 & \multicolumn{2}{|c|}{$\begin{array}{l}\text { If there are more than } 1 \text { contract in the village, please mention the name of the company } \\
\text { and year of contract. }\end{array}$} & Nama: & & \multicolumn{2}{|c|}{ Tahun: } \\
\hline 16.202 & \multicolumn{2}{|l|}{ How many HHs/farmers does this contract bind? } & \multicolumn{4}{|c|}{$\sqcup_{\text {HH }}$} \\
\hline 16.203 & \multicolumn{2}{|l|}{ How many farmers are not working on their own land (plasma lahan)? } & \multicolumn{4}{|c|}{$\longleftarrow$ HH } \\
\hline \multirow{2}{*}{\multicolumn{2}{|c|}{ Specify the following contractual conditions: }} & \multicolumn{3}{|c|}{ a } & \multicolumn{2}{|c|}{$\mathrm{b}$} \\
\hline & & \multicolumn{3}{|c|}{$\begin{array}{l}\text { How much/what is in contract? } \\
\text { (99=not in contract) }\end{array}$} & \multicolumn{2}{|c|}{$\begin{array}{c}\text { What has been } \\
\text { materialized/Has it been } \\
\text { materialized? }\end{array}$} \\
\hline 16.204 & What was the offer ratio? (50\%desa : 50\%firm) & \multicolumn{3}{|c|}{$\longleftarrow$ desa : $\longleftarrow$ firm } & \multicolumn{2}{|c|}{$\longleftarrow$ desa : $\longleftarrow$ firm } \\
\hline 16.205 & $\begin{array}{l}\text { After how many years should the desa-land be returned to work on it } \\
\text { themselves? (This is NOT about the total contract length!) }\end{array}$ & & \multicolumn{2}{|l|}{ 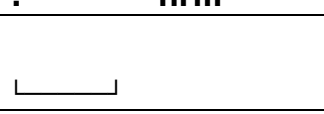 } & \multicolumn{2}{|c|}{ 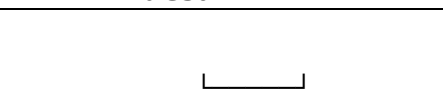 } \\
\hline 16.206 & How much loan/credit should the HHs receive? & \multicolumn{3}{|c|}{ 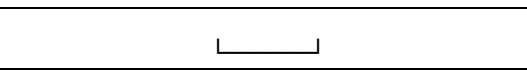 } & \multicolumn{2}{|c|}{ 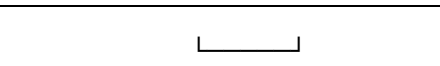 } \\
\hline 16.207 & What should be the annual interest rate on loan? (in \%) & \multicolumn{3}{|c|}{$ـ$} & \multicolumn{2}{|c|}{ 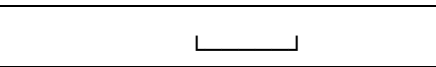 } \\
\hline 16.208 & What should be the monthly repayment rate? (in \%) & \multicolumn{3}{|c|}{ 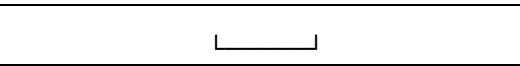 } & \multicolumn{2}{|c|}{$ـ$} \\
\hline 16.209 & After how many years should the repayment start? & \multicolumn{3}{|c|}{ 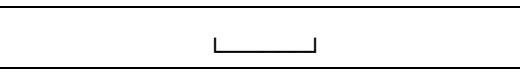 } & \multicolumn{2}{|c|}{ 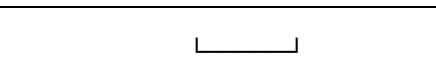 } \\
\hline 16.210 & On average, how many seedlings should be planted per hectare? & \multicolumn{3}{|c|}{$ـ$} & \multicolumn{2}{|c|}{ ــ } \\
\hline 16.211 & How much direct compensation payment per hectare should be paid? (in Rp) & \multicolumn{3}{|c|}{ 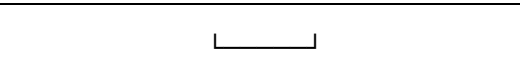 } & \multicolumn{2}{|c|}{ 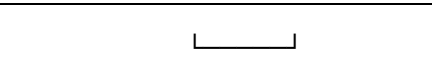 } \\
\hline 16.212 & Regular application of fertilizer should be provided in the beginning? & $\square \mathrm{Ya}$ & $\square \mathrm{Tdk}$ & $\square 99$ & $\square \mathrm{Ya}$ & $\square$ Tidak \\
\hline 16.213 & Should the company invest in schools, roads, hospitals? & $\square \mathrm{Ya}$ & $\square$ Tdk & $\square 99$ & $\square \mathrm{Ya}$ & $\square$ Tidak \\
\hline 16.214 & Should you be restricted to sell to the company only? & $\square \mathrm{Ya}$ & $\square \mathrm{Tdk}$ & $\square 99$ & $\square \mathrm{Ya}$ & $\square$ Tidak \\
\hline 16.215 & Should the company offer employment at estate before crop matures? & $\square \mathrm{Ya}$ & $\square$ Tdk & $\square 99$ & $\square \mathrm{Ya}$ & $\square$ Tidak \\
\hline 16.216 & Should the Inti land be returned after cutting oil palm trees? (after ca. 25 years) & $\square \mathrm{Ya}$ & $\square$ Tdk & $\square 99$ & $\square \mathrm{Ya}$ & $\square$ Tidak \\
\hline 16.217 & If the land has not been returned, why not? & \multicolumn{5}{|c|}{$\begin{array}{l}\text { Missing land certificates } \\
\text { Land borders not known anymore } \\
\text { other, specify }\end{array}$} \\
\hline 16.218 & \multicolumn{6}{|l|}{ Space for remarks and comments: } \\
\hline
\end{tabular}




\begin{tabular}{|c|c|c|}
\hline 16.31 & $\begin{array}{l}\text { Who was involved in bargaining about the contract? } \\
->\text { (mention all which is applicable) }\end{array}$ & $\begin{array}{l}\text { Kepala Desa } \\
\text { KUD members } \\
\text { Government official } \\
\text { company broker/investor/liaison officer } \\
\text { all villagers } \\
\text { elderly group leader } \\
\text { youth leader } \\
\text { women's group leader }\end{array}$ \\
\hline 16.32 & $\begin{array}{l}\text { Who was involved in deciding about the contract? } \\
->\text { (mention all which is applicable!) }\end{array}$ & $\begin{array}{l}\text { Kepala Desa } \\
\text { KUD members } \\
\text { Government official } \\
\text { company broker/investor/liaison officer } \\
\text { all villagers } \\
\text { elderly group leader } \\
\text { youth leader } \\
\text { women's group leader }\end{array}$ \\
\hline 16.33 & How was decision made? & $\begin{array}{l}\text { Public Vote } \\
\text { Private Vote } \\
\text { Discussion (Consensus) } \\
\text { Village Head only }\end{array}$ \\
\hline
\end{tabular}

\subsection{Contractual Prices for Oil Palm}

16.41 What is the price for one kilo Fresh Fruit Bunch (FFB) of Oil Palm last week?(Rph)

16.42 Will the farmers receive a different price after the crop matured? (after ca 10 years)

\begin{tabular}{l|l|l}
\hline 16.43 & For contract farmers, how are loans and purchases & $\square$ reduced price per kilo
\end{tabular}

(fertilizer etc.) repaid to the company?

Only for INDEPENDENT FARMERS! If no independent farmers, skip this section.

\section{Individual Smallholders without contract}

\begin{tabular}{|c|c|c|c|c|}
\hline 17.1 & \multirow{2}{*}{\multicolumn{2}{|c|}{$\begin{array}{l}\text { How much land did the independent farmer allocate to oil palm? (in } \\
\text { hectares) } \\
\text { Do they have access to high-yielding oil palm seeds? }\end{array}$}} & \multicolumn{2}{|c|}{ 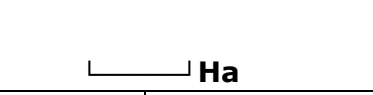 } \\
\hline 17.2 & & & $\mathrm{Ya}$ & \begin{tabular}{|l}
$\square$ \\
Tidak
\end{tabular} \\
\hline 17.3 & If YES, where are these bought? & \multicolumn{3}{|c|}{$\begin{array}{l}\text { Oil Palm Company } \\
\text { Market; } \\
\text { Other: }\end{array}$} \\
\hline 17.4 & \multicolumn{3}{|c|}{$\begin{array}{l}\text { What was the price the independent farmers received for } \underline{\mathbf{1} \mathbf{k g} \text { FFB }} \text { oil palm last } \\
\text { week? }\end{array}$} & Rph \\
\hline
\end{tabular}




\begin{tabular}{|c|c|c|c|c|c|c|}
\hline \multicolumn{7}{|c|}{ 18. Switching Crops } \\
\hline & Switching direction & Number of & Why switch? & \multicolumn{2}{|c|}{ More satisfied now? } & \multirow{2}{*}{$\begin{array}{l}\text { How many } \\
\text { HHs want to } \\
\text { switch back? }\end{array}$} \\
\hline 18.1 & Oil Palm to Rubber & $\longleftarrow$ & $\sqcup \sqcup \sqcup \sqcup$ & $\square \mathrm{Ya}$ & $\square$ Tidak & \\
\hline 18.2 & Rubber to Oil Palm & $\longleftarrow$ & 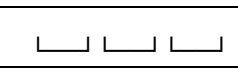 & $\square \mathrm{Ya}$ & $\square$ Tidak & $\longleftarrow$ \\
\hline 18.3 & Other: & $\longleftarrow$ & $\sqcup \sqcup \sqcup \sqcup$ & $\square \mathrm{Ya}$ & $\square$ Tidak & $\longleftarrow$ \\
\hline \multicolumn{7}{|c|}{ Codes for 18: Why Switch? } \\
\hline \multicolumn{3}{|c|}{$\begin{array}{l}1=\text { more profit than rubber/oil palm } \\
2=\text { friend/neighbor farmer switched }\end{array}$} & \multicolumn{3}{|c|}{$\begin{array}{l}3=\text { less work } \\
4=\text { other }, \text { specify: }\end{array}$} & \\
\hline
\end{tabular}

\section{Bordering Agreements}

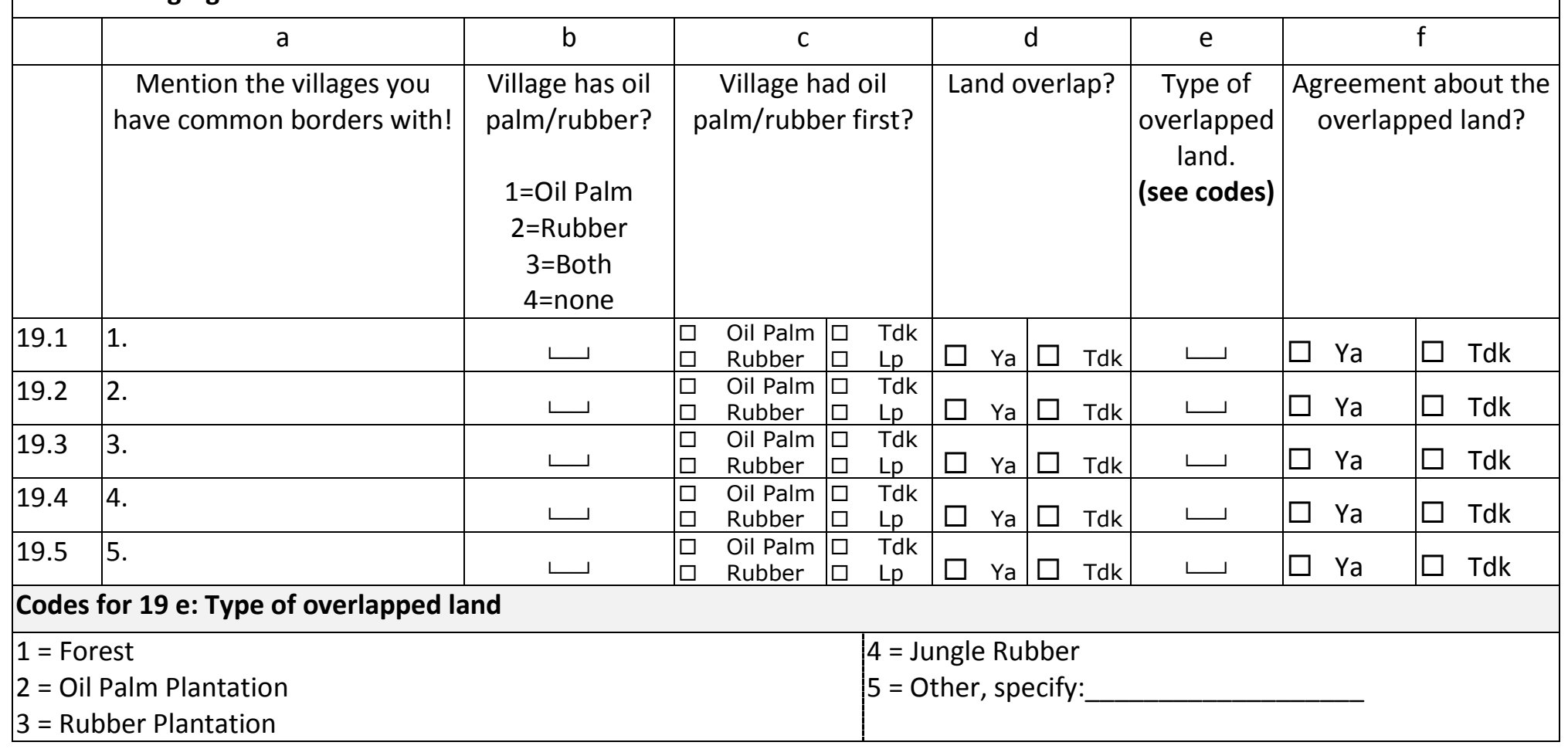

\begin{tabular}{|c|l|c|}
\hline \multicolumn{2}{|l|}{20.1 Worship } \\
\hline & How many of the following worship building does the village have? \\
\hline 20.11 & Mosque (Masjid) & \\
\hline 20.12 & Small Mosque (Surau/Langgar) & \\
\hline 20.13 & Church for Catholics & \\
\hline 20.14 & Temple & \\
\hline 20.15 & Vihara/Klenteng & \\
\hline
\end{tabular}




\subsection{Which organizations exist in and outside your village?}

\begin{tabular}{|c|c|c|c|c|c|c|c|c|c|c|c|c|c|c|}
\hline & & & & \multicolumn{11}{|c|}{ Answer this only for the biggest (most members) institution/group: } \\
\hline & \multicolumn{3}{|c|}{ a } & $\mathrm{b}$ & C & d & e & $f$ & g & $\mathrm{h}$ & $\mathrm{i}$ & & $\mathrm{j}$ & \\
\hline & \multicolumn{3}{|c|}{$\begin{array}{l}\text { How many of the following } \\
\text { institutions/groups exist in the village? }\end{array}$} & $\begin{array}{l}\text { Since } \\
\text { when? } \\
\text { (Year) }\end{array}$ & $\begin{array}{l}\text { Funding } \\
\text { Authority } \\
\text { (see codes) }\end{array}$ & $\begin{array}{l}\text { Number of } \\
\text { members }\end{array}$ & $\begin{array}{l}\text { How often } \\
\text { do they } \\
\text { meet? } \\
\text { (see codes) }\end{array}$ & $\begin{array}{l}\text { How is } \\
\text { membership } \\
\text { obtained? } \\
\text { (see codes) }\end{array}$ & $\begin{array}{l}\text { How long } \\
\text { is a period } \\
\text { in office } \\
\text { for the } \\
\text { leader? } \\
\text { (Year) }\end{array}$ & $\begin{array}{l}\text { How is } \\
\text { leader } \\
\text { chosen? } \\
\text { (see } \\
\text { codes) }\end{array}$ & $\begin{array}{l}\text { How are } \\
\text { decisions } \\
\text { made? } \\
\text { (see } \\
\text { codes) }\end{array}$ & \multicolumn{3}{|c|}{$\begin{array}{l}\text { Does the } \\
\text { institution } \\
\text { meet with } \\
\text { other groups } \\
\text { outside the } \\
\text { village? }\end{array}$} \\
\hline 20.201 & \multicolumn{2}{|l|}{ Farmer Cooperative } & $\sqcup$ & & $\longleftarrow$ & $\sqcup$ & $\longleftarrow$ & $\longleftarrow$ & & $\longleftarrow$ & $\longleftarrow$ & $\square$ Ya & $\square$ & Tdk \\
\hline 20.202 & \multicolumn{2}{|c|}{ Credit/ Saving Association } & 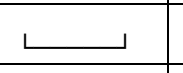 & & $\longleftarrow$ & 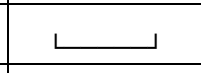 & 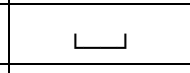 & 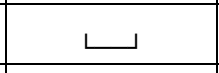 & & 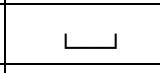 & 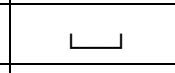 & $\square \mathrm{Ya}$ & $\square$ & $\mathrm{Tdk}$ \\
\hline 20.203 & \multicolumn{2}{|c|}{ Village council/government } & $\longleftarrow$ & & $\longleftarrow$ & 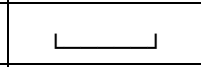 & $\longleftarrow$ & $\longleftarrow$ & & $\longleftarrow$ & $\longleftarrow$ & $\square \mathrm{Ya}$ & $\square$ & Tdk \\
\hline 20.204 & \multicolumn{2}{|l|}{ Women's group } & 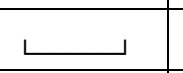 & & 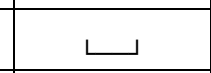 & 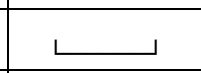 & 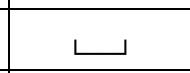 & 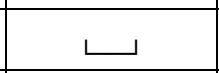 & & 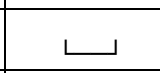 & 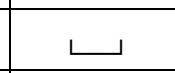 & $\square \mathrm{Ya}$ & $\square$ & Tdk \\
\hline 20.205 & \multicolumn{2}{|l|}{ Elderly Group } & 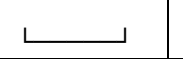 & & 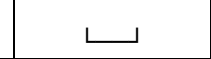 & $ـ$ & 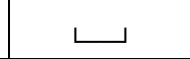 & 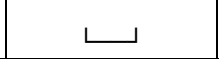 & & 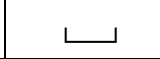 & 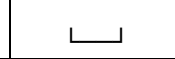 & $\square \quad \mathrm{Ya}$ & $\square$ & $\mathrm{Tdk}$ \\
\hline 20.206 & \multicolumn{2}{|l|}{ Youth Group } & 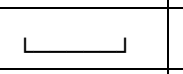 & & 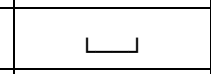 & 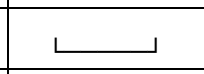 & 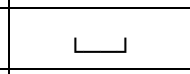 & 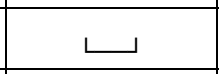 & & 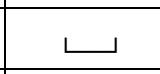 & 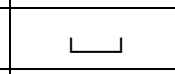 & $\square \mathrm{Ya}$ & $\square$ & $\mathrm{Tdk}$ \\
\hline 20.207 & \multicolumn{2}{|l|}{ Sport Group } & $\longleftarrow$ & & $\smile$ & 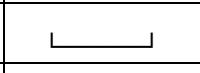 & $\smile$ & $\smile$ & & $\smile$ & $\smile$ & $\square$ Ya & $\square$ & Tdk \\
\hline 20.208 & \multicolumn{2}{|l|}{ Political Group } & $\longleftarrow$ & & 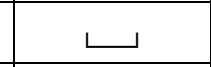 & $ـ$ & $\longleftarrow$ & 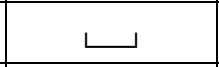 & & $\longleftarrow$ & 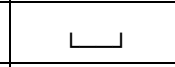 & $\square \quad \mathrm{Ya}$ & $\square$ & Tdk \\
\hline 20.209 & \multicolumn{2}{|l|}{ Environmental Group } & 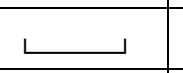 & & 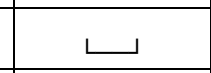 & 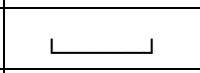 & $\longleftarrow$ & $\sqcup$ & & 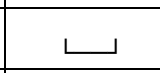 & $\longleftarrow$ & $\square \mathrm{Ya}$ & $\square$ & Tdk \\
\hline 20.210 & Other, specify: & & $\longleftarrow$ & & 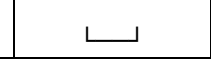 & 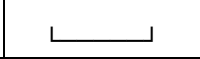 & $\longleftarrow$ & 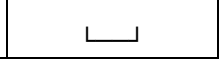 & & $\longleftarrow$ & $\longleftarrow$ & $\square$ Ya & $\square$ & Tdk \\
\hline \multicolumn{2}{|c|}{$\begin{array}{l}\text { Codes for } 20.2 \text { c: Founding } \\
\text { Authority }\end{array}$} & \multicolumn{2}{|c|}{$\begin{array}{l}\text { Codes for } 20.2 \text { e: } \\
\text { Meeting Frequency }\end{array}$} & \multicolumn{2}{|c|}{$\begin{array}{l}\text { Codes for } 20.2 \mathrm{f:} \\
\text { Membership }\end{array}$} & \multicolumn{3}{|c|}{$\begin{array}{l}\text { Codes for } 20.2 \text { h: How is leader } \\
\text { chosen? }\end{array}$} & \multicolumn{6}{|c|}{ Codes for $20.2 \mathrm{~h}$ : Decision-making } \\
\hline \multicolumn{2}{|c|}{$\begin{array}{l}1=\text { Village Head } \\
2=\text { Government Official } \\
3=\text { Villagers } \\
4=\text { NGO } \\
5=\text { Other }\end{array}$} & \multicolumn{2}{|c|}{$\begin{array}{l}1=\text { every day } \\
2=\text { once a week } \\
3=\text { once } \text { a month } \\
4 \text { = once in } 6 \text { months } \\
5 \text { = once a year }\end{array}$} & \multicolumn{2}{|c|}{$\begin{array}{l}1=\text { land ownership } \\
2=\text { compulsory } \\
3=\text { inheritance } \\
4=\text { voluntary } \\
5=\text { elected by group } \\
6=\text { elected by villagers } \\
7=\text { other: }\end{array}$} & \multicolumn{3}{|c|}{$\begin{array}{l}1=\text { inheritance } \\
2 \text { = appointed by village head } \\
3=\text { elected by group } \\
4=\text { elected by everyone in the } \\
\text { village } \\
5=\text { other, } \\
\text { specify: }\end{array}$} & \multicolumn{6}{|c|}{$\begin{array}{l}1=\text { by group leader } \\
2=\text { by discussion (census) } \\
3 \text { = by public vote within group } \\
4=\text { by secret vote within group (i.e. ballot) } \\
5 \text { = other, specify: }\end{array}$} \\
\hline
\end{tabular}




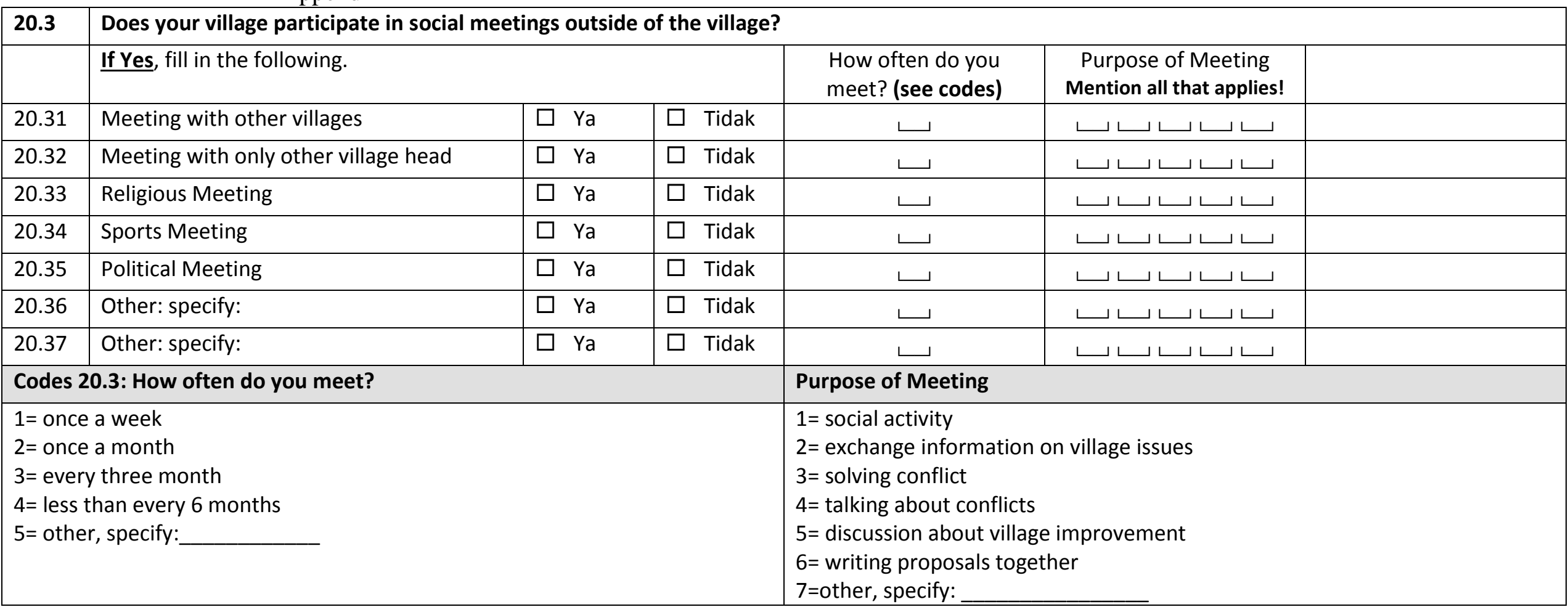

\begin{tabular}{|c|c|c|c|}
\hline 20.4 & Credit Institutions & & \\
\hline 20.401 & Does your village have the following credit institutions? & How many? & $\%$ of HHs which are depending on that institutions \\
\hline 20.402 & Commercial banks (e.g. BNI) & 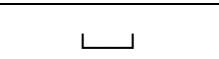 & 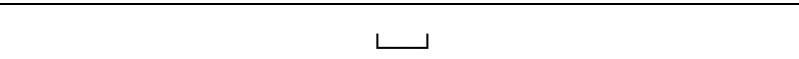 \\
\hline 20.404 & Output trader - rubber & 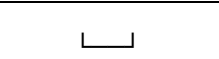 & $\sqcup$ \\
\hline 20.405 & Output trader - Oil palm & $\sqcup$ & $\sqcup$ \\
\hline 20.406 & Plantation companies (Rubber) & $\longleftarrow$ & $\longleftarrow$ \\
\hline 20.407 & Plantation companies (Oil palm) & 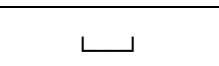 & $\sqcup$ \\
\hline 20.408 & Rice mills & 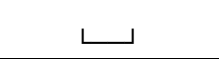 & 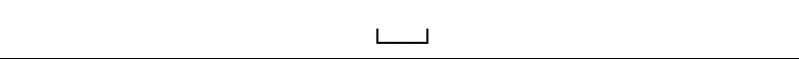 \\
\hline 20.409 & Input dealers & $\sqcup$ & $\longleftarrow$ \\
\hline 20.410 & Private money trader & 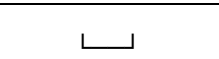 & 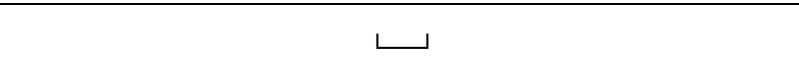 \\
\hline 20.411 & Others (specify) & $\sqcup$ & $\sqcup$ \\
\hline
\end{tabular}




\subsection{Political Organization}

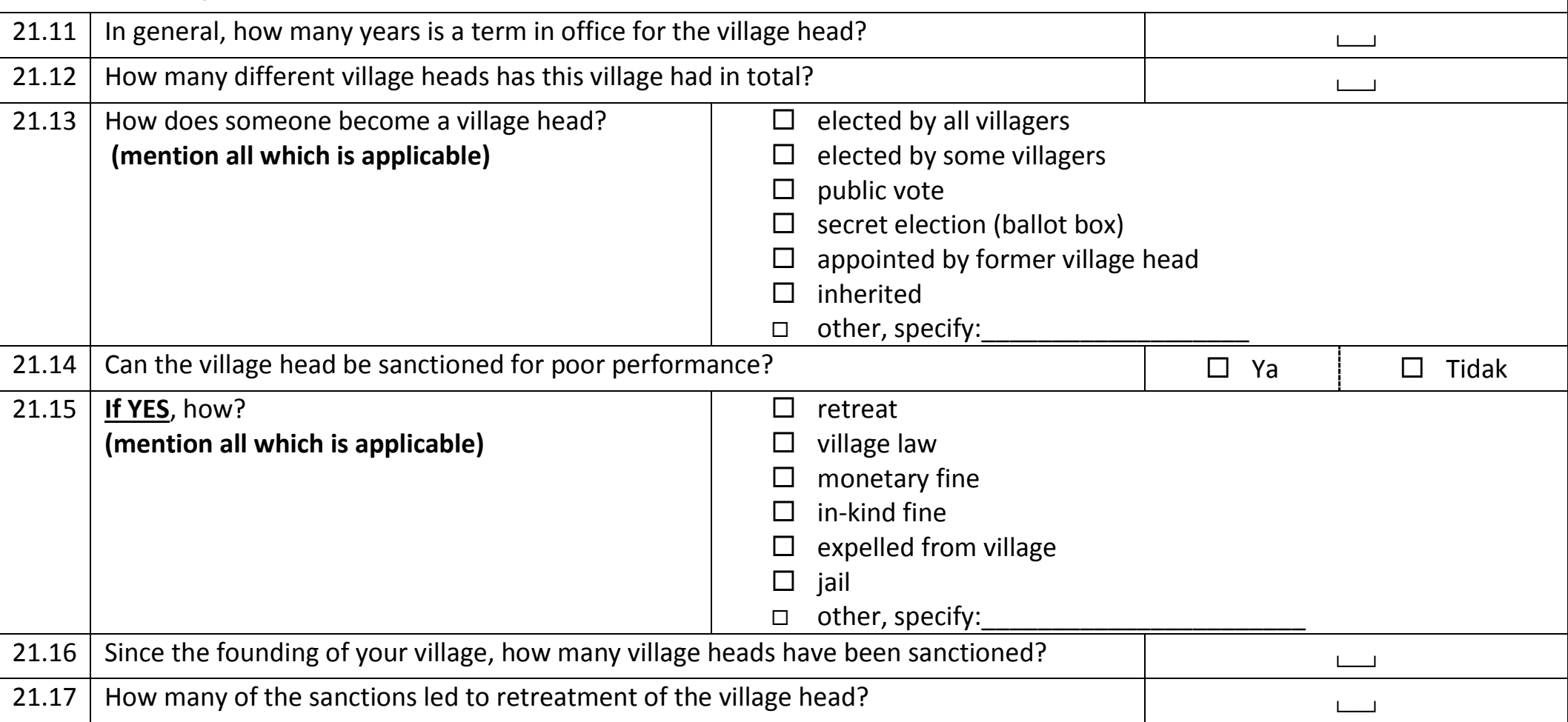

\subsection{Village Meeting}

\begin{tabular}{|c|c|c|c|}
\hline 21.21 & $\begin{array}{l}\text { How often does the village head/council have a meeting with entire } \\
\text { village? }\end{array}$ & $\begin{array}{l}\square \\
\square \\
\square \\
\square \\
\square \\
\square\end{array}$ & $\begin{array}{l}\text { once a month } \\
\text { once per } 2 \text { months } \\
\text { once per } 4 \text { months } \\
\text { once per year } \\
\text { seldom } \\
\text { never }\end{array}$ \\
\hline 21.22 & Which themes are being discussed at the meetings? & $\begin{array}{l}\square \\
\square \\
\square \\
\square \\
\square \\
\square \\
\square \\
\square\end{array}$ & $\begin{array}{l}\text { Land Conflicts } \\
\text { Family Conflicts } \\
\text { Other Conflicts, specify: } \\
\text { Ceremonies } \\
\text { Oil palm contractual agreements } \\
\text { Development projects } \\
\text { Selection of Leaders } \\
\text { Other, specify: }\end{array}$ \\
\hline
\end{tabular}




\begin{tabular}{|c|c|c|c|c|c|c|c|c|c|c|c|c|c|}
\hline \multicolumn{14}{|c|}{ 22. Land Expropriation/Grabbing } \\
\hline 22.1 & \multicolumn{5}{|c|}{ Has land been expropriated or taken away in your village? } & & $\square \quad \mathrm{YA}$ & & \multicolumn{2}{|c|}{$\square \quad$ Tidak } & & & \\
\hline \multicolumn{14}{|c|}{ If YES, please specify; if NO, skip to next section. } \\
\hline \multirow[t]{2}{*}{22.2} & a & $\mathrm{b}$ & c & \multicolumn{2}{|r|}{ d } & e & \multicolumn{2}{|r|}{ f } & \multicolumn{2}{|c|}{ g } & $\mathrm{h}$ & \multicolumn{2}{|r|}{$\mathrm{i}$} \\
\hline & $\begin{array}{l}\text { Land Type } \\
\text { (see codes) }\end{array}$ & $\begin{array}{l}\text { When? } \\
\text { (year) }\end{array}$ & $\begin{array}{l}\text { By Whom? } \\
\text { (see codes) }\end{array}$ & $\begin{array}{r}\text { How } \\
\text { (ir }\end{array}$ & $\begin{array}{l}\text { much? } \\
\text { ha) }\end{array}$ & $\begin{array}{l}\text { What Purpose? } \\
\text { (see codes) }\end{array}$ & Retu & irned? & \multicolumn{2}{|c|}{$\begin{array}{l}\text { Did any violent } \\
\text { conflicts/death } \\
\text { arise? }\end{array}$} & $\begin{array}{l}\text { Which role did the } \\
\text { village head play? } \\
\text { (see codes) }\end{array}$ & \multicolumn{2}{|c|}{$\begin{array}{l}\text { Did the behavior } \\
\text { of village head } \\
\text { cause conflict? }\end{array}$} \\
\hline 22.3 & 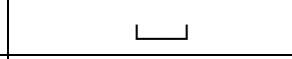 & & $\longleftarrow$ & & 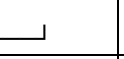 & 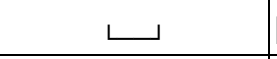 & $\square \mathrm{Ya}$ & $\square$ Tdk & $\square \mathrm{Ya}$ & $\square \mathrm{Tdk}$ & $\longleftarrow$ & $\square \quad \mathrm{Ya}$ & $\square \mathrm{Tdk}$ \\
\hline 22.4 & 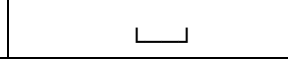 & & 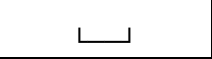 & & 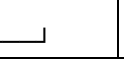 & ــ & $\square \quad$ Ya & $\square \mathrm{Tdk}$ & $\square \mathrm{Ya}$ & $\square$ Tdk & $\longleftarrow$ & $\square \quad$ Ya & $\square \mathrm{Tdk}$ \\
\hline 22.5 & 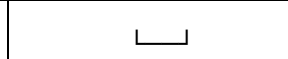 & & $\longleftarrow$ & & 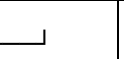 & 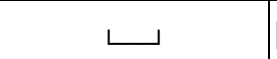 & $\square \mathrm{Ya}$ & $\square \mathrm{Tdk}$ & $\square \mathrm{Ya}$ & $\square \mathrm{Tdk}$ & 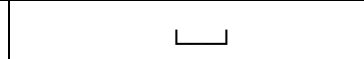 & $\square \quad \mathrm{Ya}$ & $\square \mathrm{Tdk}$ \\
\hline \multicolumn{2}{|c|}{ Codes for 22 a: Land Type } & \multicolumn{5}{|c|}{ Codes for 22 c: By Whom } & \multicolumn{4}{|c|}{ Codes for 22 e: Purpose } & \multicolumn{3}{|c|}{ Codes for 22 h: Village Head Role } \\
\hline \multicolumn{2}{|c|}{$\begin{array}{l}1=\text { Indigenous land } \\
2=\text { Transmigrasi Land } \\
3=\text { Other } \\
\text { specify: }\end{array}$} & \multicolumn{3}{|c|}{$\begin{array}{l}1=\text { Logging company } \\
2 \text { = Palm oil company } \\
3=\text { Rubber company } \\
4=\text { Provincial government }\end{array}$} & \multicolumn{2}{|c|}{$\begin{array}{l}5=\text { National government } \\
6=\text { Neighboring villages } \\
7=\text { Other } \\
\text { specify: }\end{array}$} & \multicolumn{4}{|c|}{$\begin{array}{l}1=\text { Logging } \\
2=\text { Oil palm } \\
3=\text { Conflict with neighbor } \\
4=\text { Conflict with government }\end{array}$} & \multicolumn{3}{|c|}{$\begin{array}{l}1=\text { not involved } \\
2=\text { mediating } \\
3=\text { supporting villagers } \\
4=\text { supporting company/government }\end{array}$} \\
\hline
\end{tabular}




\section{Shocks}

\begin{tabular}{|c|c|c|c|c|c|c|c|c|c|c|c|c|c|}
\hline \multirow{2}{*}{\multicolumn{2}{|c|}{$\begin{array}{l}\text { Indicate for each of the past } \\
\text { years when your village was } \\
\text { affected by the respective } \\
\text { shock }\end{array}$}} & \multirow{2}{*}{$\begin{array}{c}\text { a } \\
1992- \\
1996 \\
\text { (month } \\
\text { and year) }\end{array}$} & \multirow{2}{*}{$\begin{array}{c}b \\
1997- \\
2001 \\
\text { (month } \\
\text { and year) }\end{array}$} & \multirow{2}{*}{$\begin{array}{c}\text { c } \\
2002 \\
\text { (month) }\end{array}$} & \multirow{2}{*}{$\begin{array}{c}d \\
2003 \\
\text { (month) }\end{array}$} & \multirow{2}{*}{$\begin{array}{c}\mathrm{e} \\
2004 \\
\text { (month) }\end{array}$} & \multirow{2}{*}{$\begin{array}{c}f \\
2005 \\
\text { (month) }\end{array}$} & \multirow{2}{*}{$\begin{array}{c}\mathrm{g} \\
2006 \\
\text { (month) }\end{array}$} & \multirow{2}{*}{$\begin{array}{c}\mathrm{h} \\
\begin{array}{c}2007 \\
\text { (month) }\end{array}\end{array}$} & \multirow{2}{*}{ 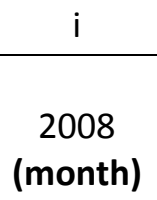 } & \multirow{2}{*}{$\begin{array}{c}j \\
2009 \\
\text { (month) }\end{array}$} & \multirow{2}{*}{$\begin{array}{c}\mathrm{k} \\
2010 \\
\text { (month) }\end{array}$} & \multirow{3}{*}{$\begin{array}{c}\text { I } \\
2011 \\
\text { (month) }\end{array}$} \\
\hline & & & & & & & & & & & & & \\
\hline 23.1 & $\begin{array}{l}\text { Too much rain } \\
\text { (flooding) }\end{array}$ & & & & & & & & & & & & \\
\hline 23.2 & Late Rain & & & & & & & & & & & & \\
\hline 23.3 & Drought & & & & & & & & & & & & \\
\hline 23.4 & $\begin{array}{l}\text { Human Disease } \\
\text { (epidemic?) } \\
\text { Specify disease in box } \\
\end{array}$ & & & & & & & & & & & & \\
\hline 23.5 & $\begin{array}{l}\text { Animal Disease } \\
\text { Specify disease in box }\end{array}$ & & & & & & & & & & & & \\
\hline 23.6 & $\begin{array}{l}\text { Crop Disease } \\
\text { Specify disease in box }\end{array}$ & & & & & & & & & & & & \\
\hline 23.7 & $\begin{array}{l}\text { Conflict } \\
\text { Specify disease in box }\end{array}$ & & & & & & & & & & & & \\
\hline 23.8 & $\begin{array}{l}\text { Other, } \\
\text { Specify disease in box }\end{array}$ & & & & & & & & & & & & \\
\hline 23.9 & $\begin{array}{l}\text { Other, } \\
\text { Specify disease in box }\end{array}$ & & & & & & & & & & & & \\
\hline
\end{tabular}




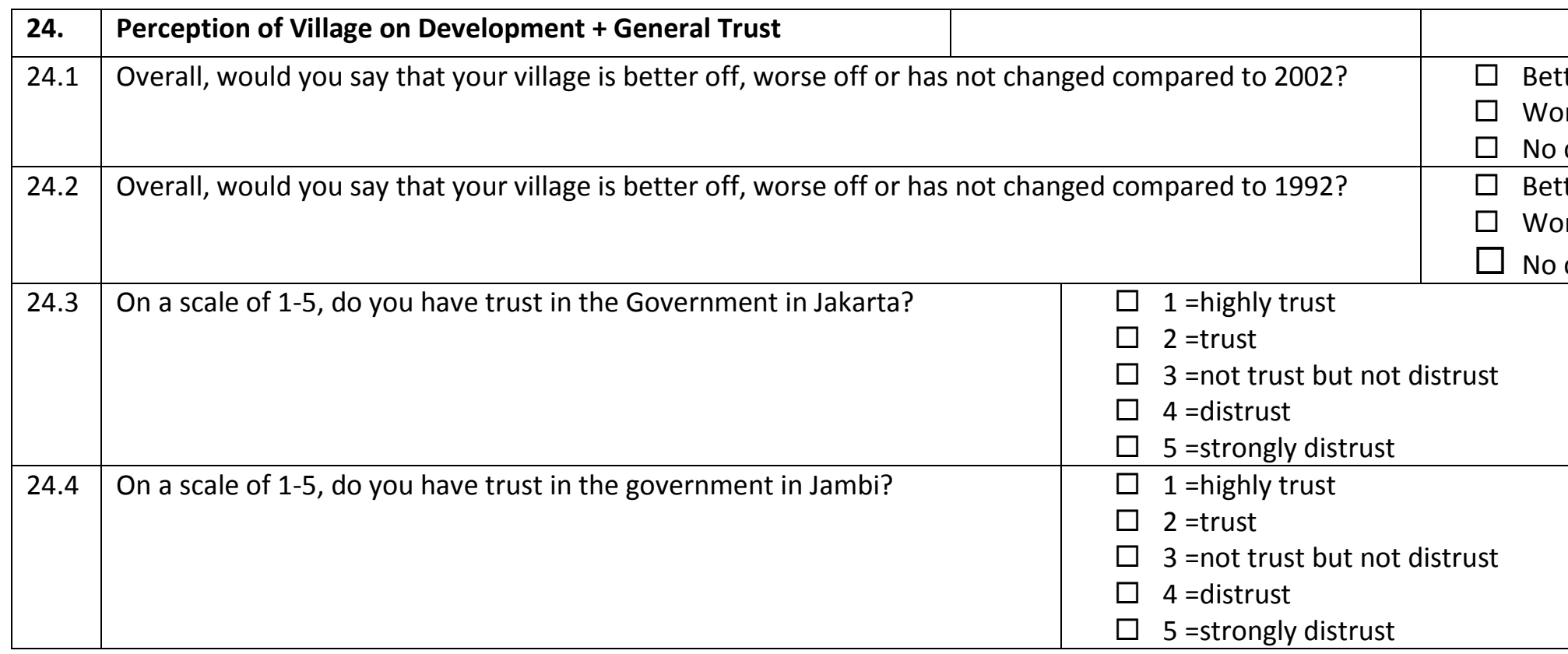

$\Rightarrow$ This is the end of the questionnaire. Thank you very much for participating!

\begin{tabular}{|l|l|l|}
\hline 0.19 & Ending time & $z_{-}:_{-}(\mathrm{hh}: \mathrm{mm})$ \\
\hline
\end{tabular}




\section{Appendix B2: Individual survey questionnaire}

\begin{tabular}{|c|c|c|c|c|c|c|}
\hline 0.1 & Village Name & & & 0.3 & \multicolumn{2}{|l|}{ Respondent Name } \\
\hline 0.2 & Village ID & & & 0.4 & \multicolumn{2}{|l|}{ Repondent ID } \\
\hline 1.01 & Sex & \multicolumn{4}{|c|}{$1=$ male; 2 = female } & $\longleftarrow$ \\
\hline 1.02 & Age & & $\sqcup$ \\
\hline 1.03 & Years of Education & & $\sqcup$ \\
\hline 1.04 & HH-Size & & \llcorner \\
\hline 1.05 & Parents & \multicolumn{4}{|c|}{ Do you have children? 1=yes; $2=$ no } & $\sqcup$ \\
\hline 1.06 & Religion & \multicolumn{4}{|c|}{$\begin{array}{l}\text { 1=Islam; 2=Hindu; 3=Protestan; 4=Katolik; } \\
\text { 5=Pantekosta; 6=Buddha; 7=Konghucu; 8=Other, } \\
\text { specify: }\end{array}$} & \llcorner \\
\hline 1.07 & Main Crop & \multicolumn{4}{|c|}{$\begin{array}{l}\text { 1=Palm Oil; 2=Jungle Rubber; 3=Rubber Plant; } \\
\text { 4=Others, specify: }\end{array}$} & \llcorner \\
\hline 1.08 & $\begin{array}{l}\text { Daily working } \\
\text { hours }\end{array}$ & \multicolumn{4}{|c|}{$\begin{array}{l}\text { How many hours do you work per day, on average? } \\
\text { (in hours) }\end{array}$} & \llcorner \\
\hline 1.09 & $\begin{array}{l}\text { Working days per } \\
\text { week }\end{array}$ & \multicolumn{4}{|c|}{$\begin{array}{l}\text { How many days do you work per week? } \\
\text { (in days) }\end{array}$} & \llcorner \\
\hline 1.10 & Contract & \multicolumn{4}{|c|}{$\begin{array}{l}\text { Do you have a contract with an Oil Palm Company? } \\
\mathbf{1 = y e s ;} \mathbf{2}=\text { no }\end{array}$} & $\longleftarrow$ \\
\hline 1.11 & $\mathrm{HH}$ assets & \multicolumn{4}{|c|}{ 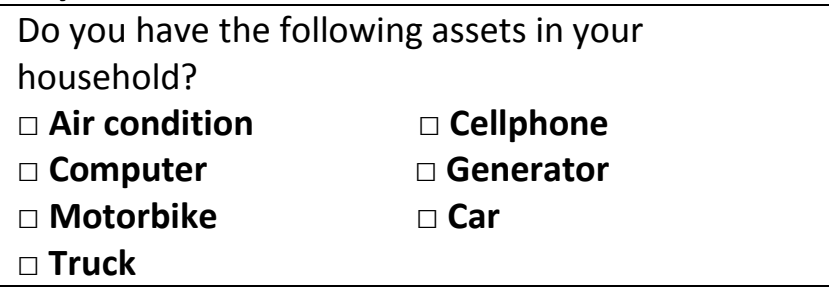 } & \\
\hline 1.12 & Insurance & \multicolumn{4}{|c|}{$\begin{array}{l}\text { Do you have a health insurance? } \\
\text { 1=yes; } \mathbf{2 = n o}\end{array}$} & $\sqcup$ \\
\hline 1.13 & Information & \multicolumn{4}{|c|}{$\begin{array}{l}\text { Are you using one of the following sources for } \\
\text { information and news? } \\
\square \text { Newspaper } \quad \square \text { News in television } \\
\square \text { Internet café } \quad \square \text { Radio } \\
\square \text { Other, specify: }\end{array}$} & \\
\hline \multicolumn{7}{|c|}{ 2. Are you a member of one of the following organizations/groups? $1=$ YES , $\mathbf{2}=$ NO } \\
\hline 2.01 & \multicolumn{2}{|l|}{ Farmer Cooperative } & $\sqcup$ & 2.06 & Youth Group & $\longleftarrow$ \\
\hline 2.02 & \multicolumn{2}{|c|}{ Credit/ Saving Association } & $\sqcup$ & 2.07 & Sport Group & $\sqcup$ \\
\hline 2.03 & \multicolumn{2}{|c|}{ Village council/government } & 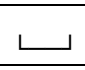 & 2.08 & Political Group & 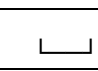 \\
\hline 2.04 & \multicolumn{2}{|l|}{ Women's group } & $\sqcup$ & 2.09 & Environmental Group & $\longleftarrow$ \\
\hline 2.05 & Elderly Group & & 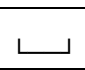 & 2.1 & Other, specify: & 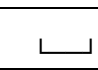 \\
\hline
\end{tabular}




\begin{tabular}{|c|c|c|c|c|c|c|}
\hline \multicolumn{7}{|c|}{ 3. Please specify the following for the other participants from the game. } \\
\hline & & & & \multicolumn{3}{|c|}{ If Relation $=4$, skip the rest } \\
\hline & & & & \multirow[b]{2}{*}{\begin{tabular}{l}
\multicolumn{1}{c}{ a } \\
Would you \\
tell him/her a \\
secret about \\
family \\
matters? \\
1=YES; $2=$ NO
\end{tabular}} & \multirow{2}{*}{\begin{tabular}{l}
\multicolumn{1}{c}{ b } \\
Received \\
gift/loan last \\
3 months? \\
1=YES; $2=$ NO
\end{tabular}} & \multirow{2}{*}{\begin{tabular}{|l|}
\multicolumn{1}{c|}{ C } \\
Granted \\
gift/loan last 3 \\
months? \\
1=YES; 2=NO
\end{tabular}} \\
\hline & $\begin{array}{l}\text { Name } \\
\text { (The names } \\
\text { will be filled in } \\
\text { beforehand by } \\
\text { enumerator) }\end{array}$ & ID & $\begin{array}{l}\text { Relation } \\
\text { 1= Family } \\
\text { 2=Friend } \\
\text { 3=Neighbor } \\
\text { 4=Don't know } \\
\text { him/her }\end{array}$ & & & \\
\hline 3.1 & & & 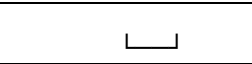 & $\longleftarrow$ & $\longleftarrow$ & $\longleftarrow$ \\
\hline 3.2 & & & $\longleftarrow$ & \llcorner & $\sqcup$ & $\sqcup$ \\
\hline 3.3 & & & $\longleftarrow$ & $\longleftarrow$ & $\longleftarrow$ & $\longleftarrow$ \\
\hline 3.4 & & & $\longleftarrow$ & \llcorner & \llcorner & $\longleftarrow$ \\
\hline 3.5 & & & 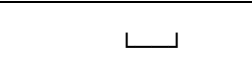 & $\sqcup$ & $\sqcup$ & $\sqcup$ \\
\hline 3.6 & & & 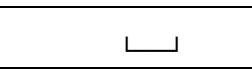 & $\longleftarrow$ & $\longleftarrow$ & $\longleftarrow$ \\
\hline 3.7 & & & $\sqcup$ & $\sqcup$ & $\longleftarrow$ & $\sqcup$ \\
\hline 3.8 & & & $\longleftarrow$ & 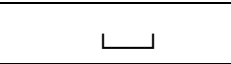 & 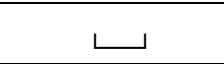 & $\longleftarrow$ \\
\hline 3.9 & & & 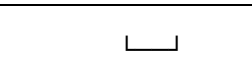 & \llcorner & $\longleftarrow$ & \llcorner \\
\hline
\end{tabular}

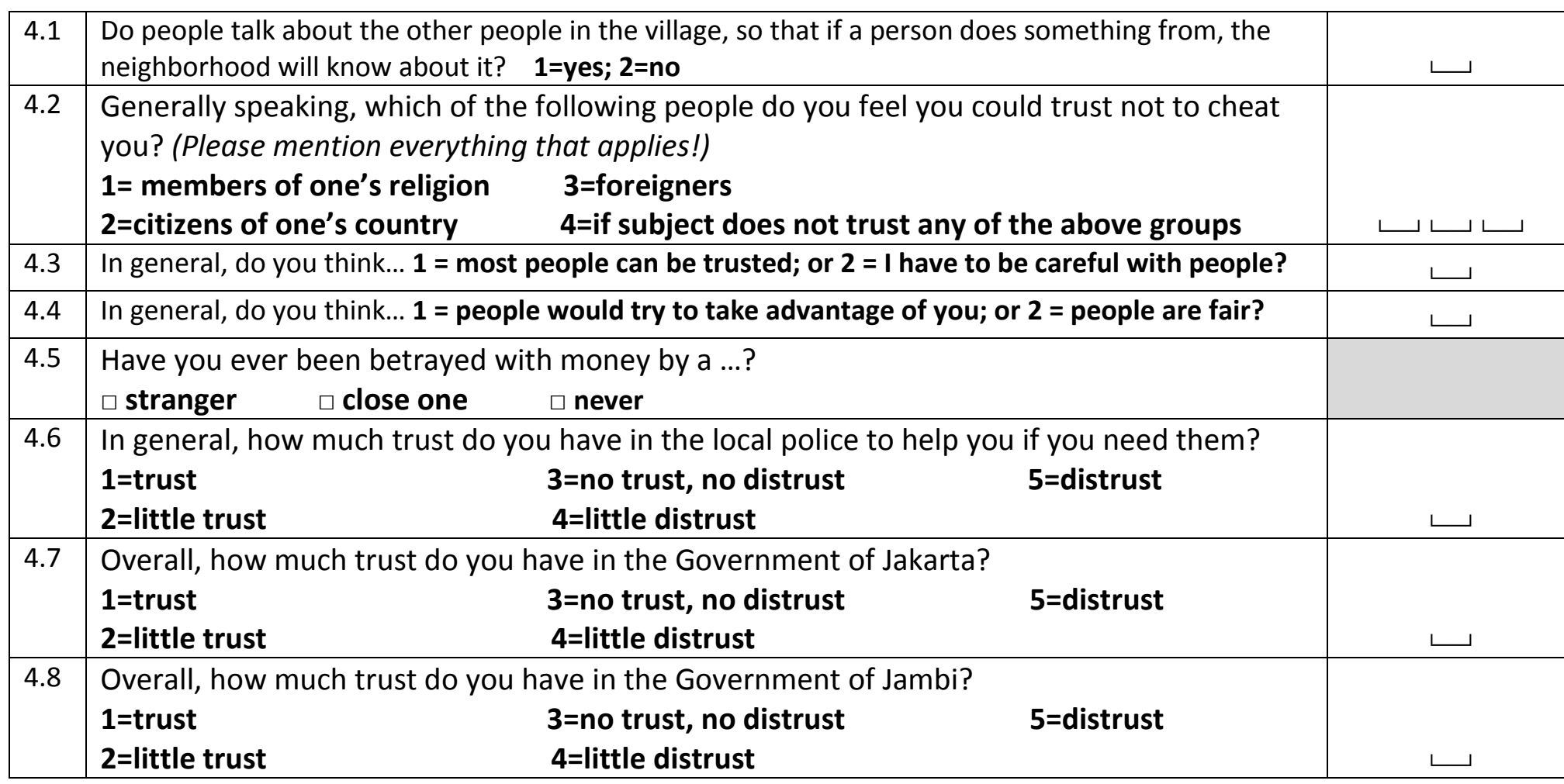

This is the end of the survey. Please ask the respondent for the mobile phone number and the current amount of Pulsa he has on his phone, and we will transfer the money. 


\section{Appendix C: Script for trust experiment}

Welcome to this game. In this game you can earn some money. This money will be given out in the end of the game in form of credit for your mobile phone. The amount of credit that you may earn does not depend on luck. Rather it depends on your decision and the decision of another participant.

The people that are here were randomly chosen to be part of this game. In this game there are two roles: the sender and the receiver. As a sender you will be paired with a second participant out of this group, a receiver. But none of you will know with whom you will be paired.

In the beginning of the game each sender and receiver will receive monopoly money which is worth 20,000 Rupiah.

\section{Sender - Instructions}

The sender is invited to make a decision: how much to send to the receiver and how she wants to keep for herself. This can be any amount of her 20,000 monopoly money. The amount sent to the receiver will be tripled. The receiver gets the tripled amount and makes a decision. How much to send back to the sender and how much to keep for herself.

As a sender, your final earning is the amount you kept plus the amount the receiver sent back to you.

\section{Receiver - Instructions}

Remember, as a receiver you also have 20,000 monopoly money in the beginning. In addition you will get an envelope with money from a sender. But you don't know who the sender is. You can make a decision: how much you want to return to the sender. And how much you want to keep for yourself.

As a receiver, the final earning is the amount you keep for yourself. 


\section{Examples:}

1. The sender decides to send everything, 20,000 and keeps nothing. The receiver, who has 20,000 will now get an additional 60,000; she is deliberate in choosing how much she wants to return. Imagine she sends back 40,000. The final earning of both, sender and receiver, will be 40,000.

2. The sender decides to send everything, 20,000, and keeps nothing. The receiver, who has 20,000 will now get an additional 60,000; she is deliberate in choosing how much she wants to return. Imagine she sends back 20,000. The final earning of the sender will be 20,000 . Whereas the final earning of the receiver, will be 60,000 .

3. The sender decides to send nothing and keep the 20,000 for herself; the receiver will receive nothing and decides to send back nothing either. In the end of the game both will get 20,000. 